This issue is dedicated to the memory

$$
\text { of }
$$

Professor A6dE[-Moneim Mohamed Hegazi, 1943-2015

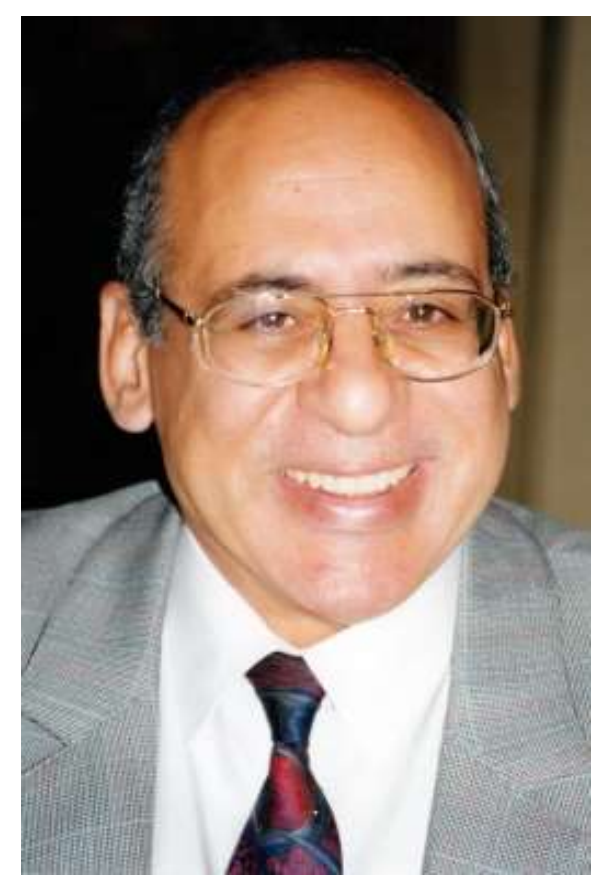

Professor of Agronomy

Chairman of Desert Research Center

Egyptian Focal Point of UNCCD and

Chairman of the SNational Scientific Committee of Combating Desertification 


\title{
ASSESSMENT AND MAPPING OF DESERTIFICATION SENSITIVITY IN THE NORTHWESTERN COASTAL ZONE, EGYPT
}

\section{Editorial Board}

\author{
Dr. A.M. Hegazi \\ Dr. A.A. Elwan \\ Dr. S.M. Abdel-Mogith \\ Dr. M.A. Wassif \\ Dr. S. El-Demerdashe \\ Dr. M.Y. Afifi \\ Dr. M. Moawad
}

Revised by

Dr. Asmaa Shata

\section{Desert Research Center (DRC)}

Matareya, Cairo, Egypt

*Corresponding author: hegazi_abdelmonem@yahoo.com 


\section{CONTRIBUTORS}

Dr. A.M.Yossif (DRC)

Dr. A. Khedr (Fac. Sci., Dommiat)

Dr. Nahla A. Morad (DRC)

Dr. S.F. Tadrous (DRC)

Dr. M.S. El-Banna (DRC)

Dr. Sawsan M. Mohamed (DRC)
Dr. M.A. Tawfik (DRC)

Dr. M.H. Zaki (DRC)

Dr. A.E. Abdel-Fattah (DRC)

Dr. M. Kamel (DRC) 


\section{PREFACE}

Egypt ratified the united Nation convention to combat Desertification (UNCCD) in 1995. The first commitment of the countries that ratified the UNCCD is the preparation of their National Action program (NAP) to combat desertification and prescribes environmentally practical and sound measure to combat desertification.

To ensure the success and achievement of Egyptian NAP in 2005, the DRC in its current 5 years plan started a magnificent program to assess and evaluate desertification in Egypt.

Within this frame, Egypt is endowed with four main agro-ecological zones;

- Nile Valley and Delta.

- North Coastal Zone.

- The Inland Sinai and the Eastern Desert.

- $\quad$ The Western Desert.

These zones are having specific attributes of resource base, climatic features, terrain and geomorphic characteristics, land use patterns and socioeconomic implications. As a consequence, the first stage will be devoted to the North-Western Coastal Zone (NWCZ).

In the present work, the Northwestern coast as a part of the North Coastal Zone was firstly studied, because in the recent decades, a lot of changes in land use and land cover have been induced mostly by man and resulted in acceleration of different degradation processes. In this specific portion, many descriptive studies are available; however the quantification of the land degradation issues is clearly missed. Therefore, the current work is devoted to the quantification.

Accordingly, the ESA's to desertification is distinguished and mapped using certain key indicators for assessing the land capability that withstand further degradation or the land suitability or supporting specific types of land use. It is hoped that this work will contribute essentially to magnifying some causes of desertification and suggest the effective measure to combat such unfavourable phenomenon.

\section{A.M. Hegazi \\ DRC}




\section{LIST OF ACRONYMS}

\begin{tabular}{ll} 
ASR & Actual Stock Rate \\
CQI & Climate Quality Index \\
DEM & Digital Elevation model \\
DRC & Desert Research Center \\
DP & Drift Potential \\
DSI & Desertification Sensitivity Index \\
EQI & Erosion Quality Index \\
ESA's & Environmentally Sensitive Areas \\
ET & Evapotranspiration \\
FAO & Food and Agriculture Organization \\
GIS & Geographic Information System \\
GQI & Groundwater Quality Index \\
HLUI & High Land Use Intensity \\
LLUI & Low Land Use Intensity \\
MEDLUS & Mediterranean Desertification and Land Use Project \\
MI & Mobility Index \\
MLUI & Medium Land Use Intensity \\
MQI & Management Quality Index \\
NAP & National Action Program \\
NWCZ & North Western Coastal Zone \\
PE & Precipitation Effectiveness \\
PET & Potential Evapotranspiration \\
QM & Quality Measurement \\
RDD & Resultant Drifts Directions \\
RDP & Resultant Drifts Potential \\
RQI & Runoff Quality Index \\
SQI & Soil Quality Index \\
SSR & Sustainable Stock Rate \\
UNCCD & United Nations Convention to Combat Desertification \\
UNEP & United Nations Environmental Program \\
USLE & Universal Soil Loss Equation \\
VQI & Vegetation Quality Index \\
& \\
\hline
\end{tabular}





\section{CONTENTS}

Page

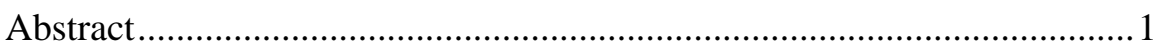

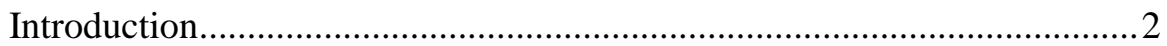

1. Physical Setting............................................................................... 3

1.1. Location .......................................................................... 3

1.2. Regional Geomorphology ............................................. 3

1.3. Geology ................................................................. 8

1.4. Climate Characteristics ................................................ 8

1.4.1. Rainfall analysis................................................ 11

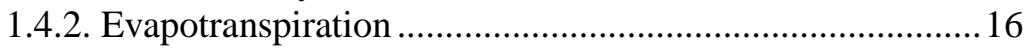

1.4.3. Wind Speed and direction .......................................... 17

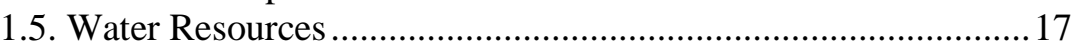

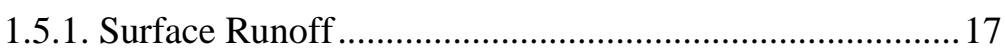

1.5.2. Groundwater Analysis .............................................. 21

1.6. Natural Vegetation and Agricultural Crops ............................223

2. Use of Remote Sensing and Geographic Information System (GIS) in Mapping Desertification Sensitivity Areas ............................................ 27

2.1. Image Processing and Analysis ............................................28

2.2. Geographic Information Systems (GIS) Applications ................28

3. Quality Measurement of the Environmentally Sensitive Areas (ESAs) to

Desertification.........................................................................29

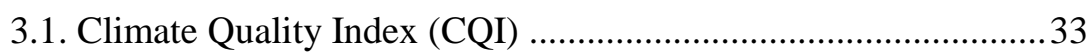

3.1.1 Rainfall index (Ir) .................................................. 34

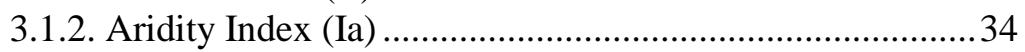

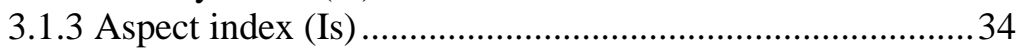

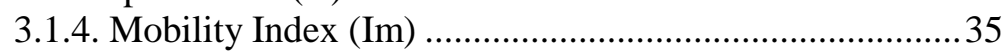

3.1.5. Calculation of the climate quality index (CQI) ...............40

3.2. Runoff Quality Index (RQI) ..............................................4 41

3.3. Groundwater Quality Index (GQI) ........................................4 42

3.4. Soil Quality Index (SQI) ...................................................44

3.4.1. Soil Characteristics and Classification............................44

3.4.2. Parameters used for assessment of soil quality ................49

3.4.2. Calculation of Soil Quality Index ..................................53

3.5. Erosion Quality Index (EQI) ..............................................55

3.5.1. Soil Erosion by Water ...................................................55

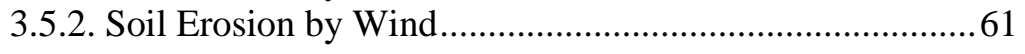

3.5.3. Calculation of Erosion Quality Index ...........................65

3.6. Vegetation Quality Index (VQI) ........................................68 
3.7. Management Quality Index (MQI) 80

3.7.1. Land use intensity

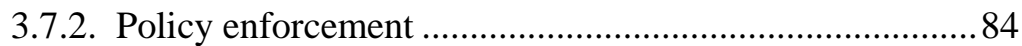

3.7.3. Calculation of. Management Quality Index (MQI) ...........85

4. Environmental Sensitivity Areas Index (ESAI) ....................................... 86

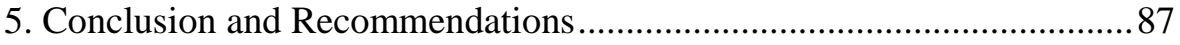

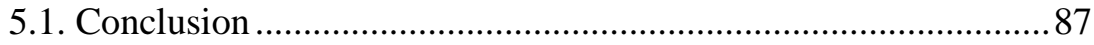

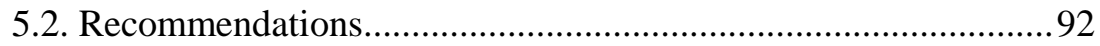

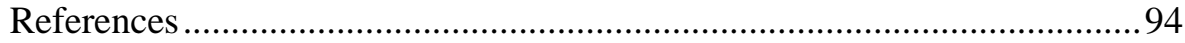

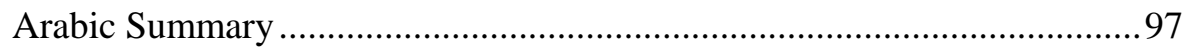




\title{
ASSESMENT AND MAPPING OF DESERTIFICATION SENSITIVITY IN THE NORTHWESTERN COASTAL ZONE, EGYPT
}

\author{
Hegazi, A.M. ${ }^{1^{*}}$; A.A. Elwan ${ }^{2}$; S.M. Abdel-Mogith ${ }^{3 ;}$ M.A. Wassif ${ }^{4}$; \\ S. El-Demerdashe ${ }^{5}$ M.Y. Afifi ${ }^{6}$ and M. Moawad ${ }^{7}$ \\ ${ }^{1}$ Department of Plant Production, Desert Research Center, El-Matareya, \\ Cairo, Egypt. \\ ${ }^{2,7}$ Department of Pedology, Desert Research Center, El-Matareya, Cairo, \\ Egypt. \\ ${ }^{3}$ Department of Hydrology, Desert Research Center, El-Matareya, Cairo, \\ Egypt. \\ ${ }^{4}$ Department of Soil Conservation, Desert Research Center, El-Matareya, \\ Cairo, Egypt. \\ ${ }^{5,6}$ Department of Soil Chemistry and Physics, Desert Research Center, El- \\ Matareya, Cairo, Egypt. \\ "E-mail: hegazi_abdelmonem@yahoo.com
}

$\mathrm{T}$ he present work aims at assessment and mapping the environmental sensitivity areas for desertification of the northwestern coastal zone (NWCZ), using the mathematical model by Kosmas, et.al. (1999). The study area extends from Alexandria to El-Sallum, it occupies an area of about 2.4 million feddan and it is located between longitudes $25^{\circ} 10^{\prime}$ and $29^{\circ} 50^{\prime} \mathrm{E}$ and latitudes $30^{\circ} 30^{\prime}$ and $31^{\circ} 40^{\prime} \mathrm{N}$.

Environmental Sensitivity Areas (ESAs) for desertification at the NWCZ were carried out through the measurement of indicators namely; climate quality index (CQI), run off quality index (RQI), groundwater quality index (GQI), soil quality index (SQI), erosion quality index (EQI), vegetation quality index (VQI) and management quality index (MQI). Accordingly, the following results are obtained for the NWCZ:

- $\mathrm{CQI}$ is low.

- RQI is moderate west Matruh and it is low east Matruh.

- GQI is moderate east Barrani and it is low west Barrani.

- SQI is moderate for about $66.65 \%$ of the area, and it is low for about $32.35 \%$.

- EQI is moderate along the NWCZ, except the area from Dabaa to Um El Rakham, it is high.

- VQI is ranging from low to moderate.

- MQI is low. 
- ESAs is considered to be of critical type degradation of first and second degree.

From this study, it is concluded that, lands development in the NWCZ is preferred in lands of low sensitivity to desertification. Also attention should be given to monitoring and controlling wind erosion as well as appropriate use of ground water in sustainable development, meanwhile, evaluating the cost-effectiveness of policy for land use planning.

Keywords: Egypt, Northwestern coastal zone, Desertification assessment and mapping, Desertification sensitivity, Climate Quality Index, Run-off Quality Index, Groundwater Quality Index, Soil Quality Index, Erosion Quality Index, Vegetation Quality Index, Management Quality Index.

\section{INTRODUCTION}

Desertification is land degradation in arid, semi-arid and dry sub humid regions and the causative factors are mainly anthropogenic and climatic. This phenomenon is one of the global problems that has confronted human beings in the recent decades and its hazards are more pronounced in developing countries, due to overpopulation and scarcity of natural resources. As a consequence, the progressive decrease of cultivated lands is due to degradation and factors enhancing such degradation together with the misuses of agricultural lands. This degradation leads to feed shortage, rural poverty and vulnerable ecosystem, malnutrition, unemployment, migration to cities or abroad and finally ensuing demography imbalance and communities' instability.

Egypt is one of the countries that has been affected by desertification and its negative impact on socio- economy, food security and social stability. It was among the first countries that ratified the UNCCD, declared its commitment through the preparation and approval of the national action plan (NAP) in 2005, and actively participated in all workshops, seminars conferences, also the submitting of the national reports.

Therefore, Desert Research Center (DRC) in its current 5 years' plan started a magnificent program to assess and evaluate desertification in Egypt which is generally divided into four agro-ecological zones, namely the North Coastal Zone, Nile Valley \& Delta, Western Desert and Inland Sinai\& Eastern Desert, provided that the first stage of this plan will be devoted to the northwestern coastal zone (NWCZ).

The assessment and mapping of the ecosystems sensitivity to desertification and degradation vulnerability of land on the national level is needed by scientists to understand processes and to develop appropriate 
methods for resources conservation. It is also needed by policy makers and land use planners to identify strategies that reverse degradation trends. Certainly, mapping on the basis of numerical analysis is very important for quantitative evaluation of the severity of the degradation problems. Detecting the problem and its control consequently worth effort and allocated funds.

The present work represents a brief account of natural resources, principles and methods for evaluating desertification sensitivity at the NWCZ using a model after Kosmas et al. (1999). Finally, the study pointed out a set of guidelines and recommendations to be followed for combating desertification to achieve sustainable development of the NWCZ.

\section{1- PHYSICAL SETTING}

\subsection{Location}

The concerned study area represents the coastal strip of the Northwestern Coastal Zone (NWCZ) which extends from Alexandria on the East to El-Sallum on the far West for about $500 \mathrm{~km}$ with an inland depth of $20 \mathrm{~km}$ South. Therefore, it occupies an area of about $10,000 \mathrm{~km}^{2}(2.4$ million feddan). Geographically, the area is located between latitudes $30^{\circ} 30^{\prime}$ and $31^{\circ}$ $40^{\prime} \mathrm{N}$ and longitudes $25^{\circ} 10^{\prime}$ and $29^{\circ} 50^{\prime} \mathrm{E}$, (Figure 1).

\subsection{Regional Geomorphology}

The area is generally divided into the following geomorphologic units as shown in figures $(2,3)$ (Saleh, 2000)

\section{i) The Coastal Plain}

The average width of the coastal plain is about $60 \mathrm{~km}$. The coastal plain stretches, generally, in east-west direction and bounded by the sea to the north and a piedmont plain to the south. This area is covered by sediments, which belong to the Quaternary age. These sediments are comprised of the following :

1) A number of ridges parallel to the shoreline, formed of porous Oolitic Limestone.

2) Sabkhas deposits, which are found in the Arab Gulf and El-Sallum Gulf in the West.

3) Sand dunes.

\section{ii) The Piedmont Slopes}

The piedmont slope in the area of study is considered as a transition zone between the foot of the escarpment and the coastal plain. The piedmont slope is considered as a good collector for water that can be infiltrated to the subsurface aquifers. The hydrographic basins which depend on the piedmont slope are well represented in Burg El Arab (Abu Mina Basin), Fuka basin and El-Sallum Gulf. 


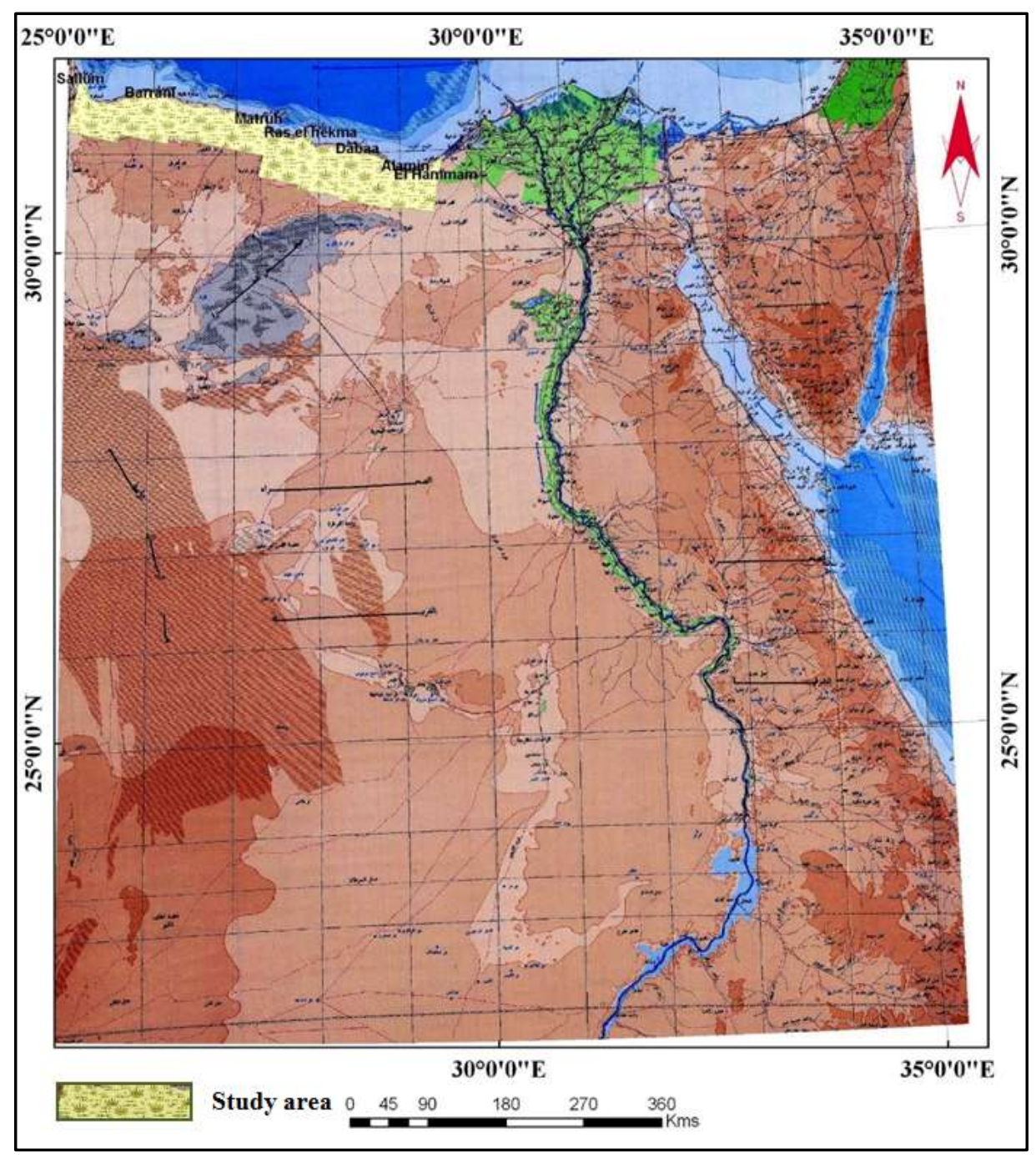

Fig. (1). Location of the NWCZ, Egypt.

Egyptian J. Desert Res., 59, 1-96 (2009) 


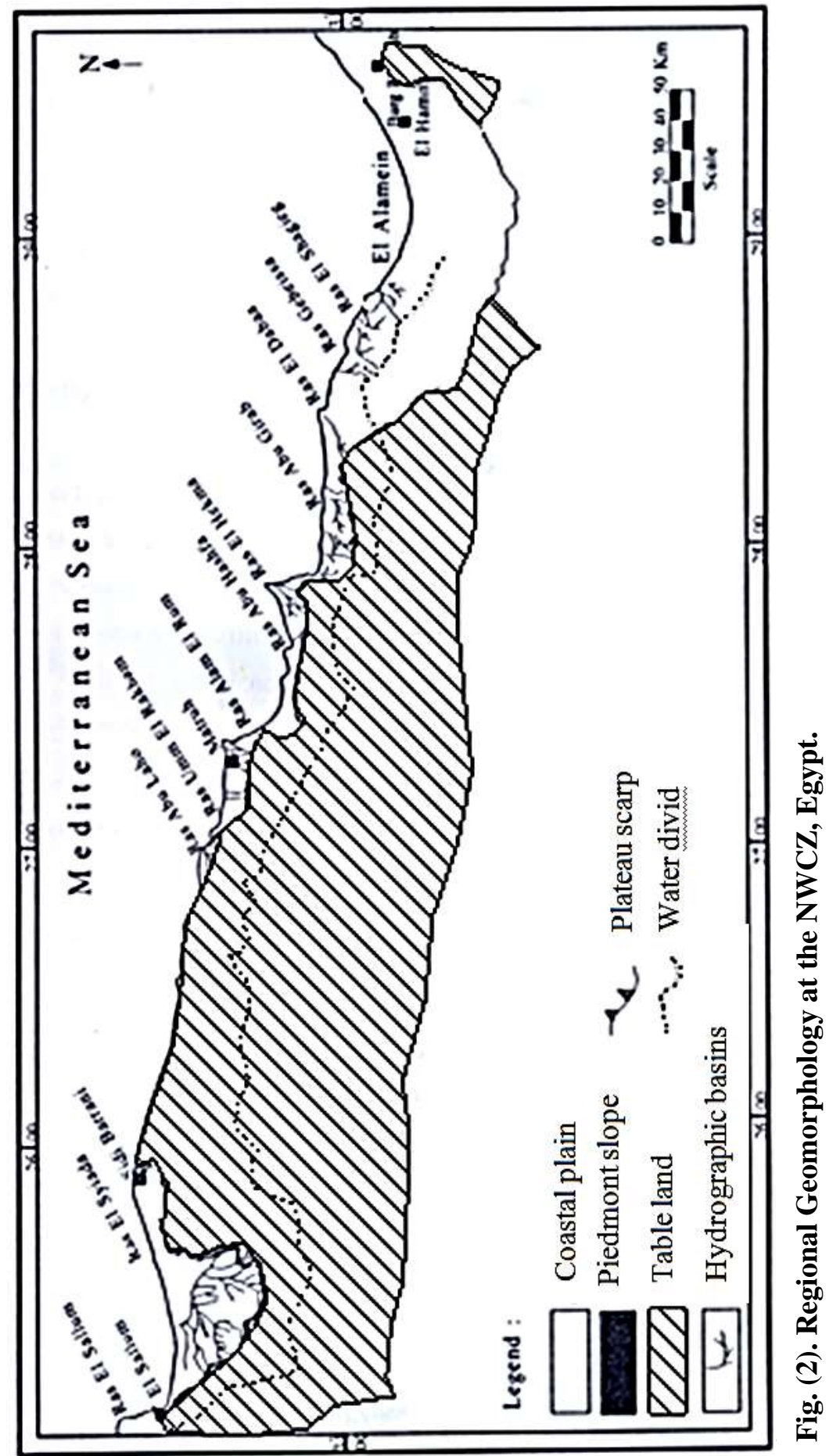




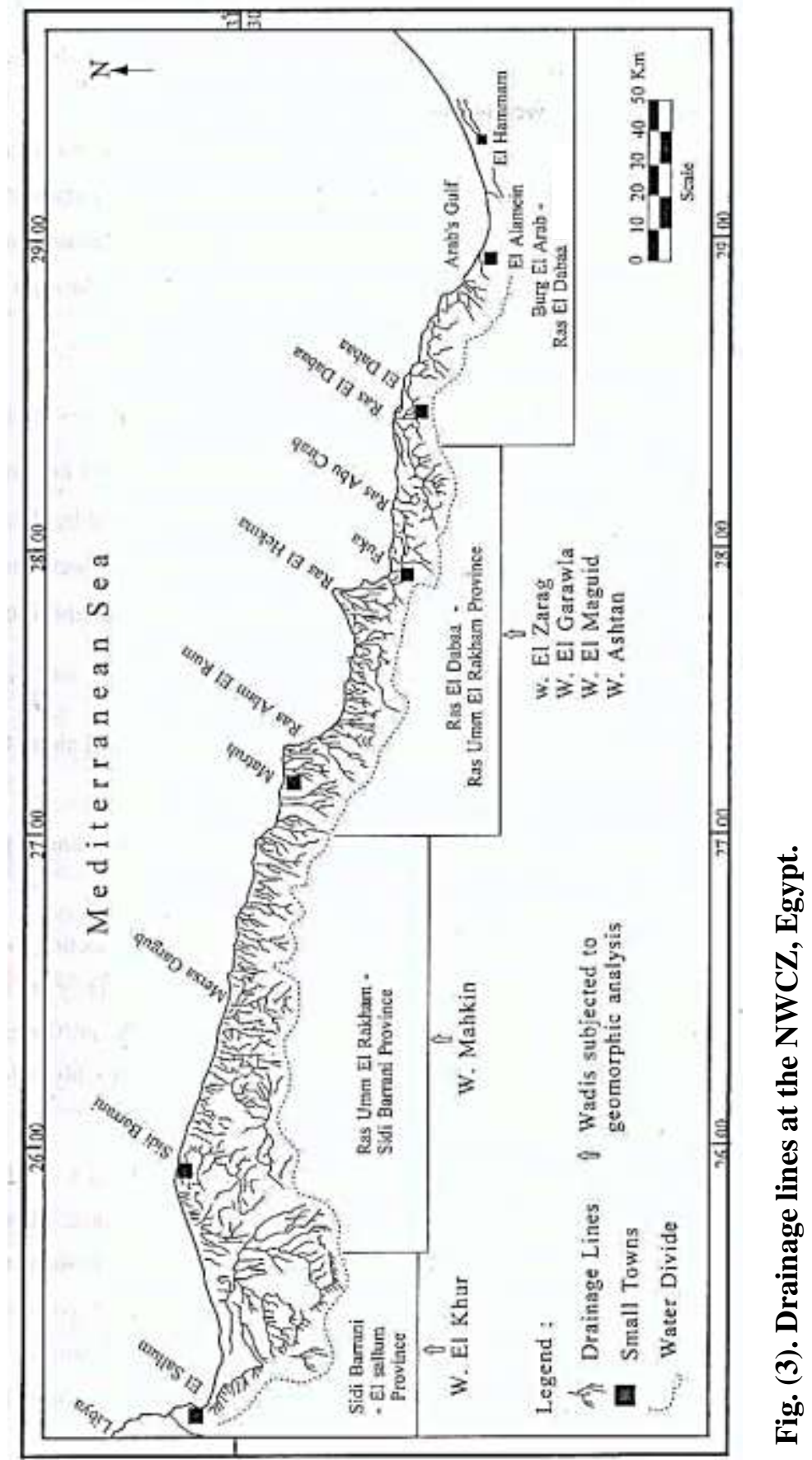

Egyptian J. Desert Res., 59, 1-96 (2009) 


\section{iii) The Tableland}

It occupies the northern edge of the high structural plateau (Marmarica Plateau) of the western desert of Egypt. The tableland mainly consists of Middle Miocene and Lower Miocene rocks, while to the east of the study area (between Burg El Arab and El Alamein) Pliocene deposits and Pleistocene thin layer of detritus oolitic limestone were encountered in the subsurface or exposed on the surface overlying the Miocene rocks. The Tableland rises gradually with a maximum altitude of about $100 \mathrm{~m}$ above sea level.

The Marmarica plateau is covered by sedimentary rocks of Tertiary age (middle Miocene). This plateau mainly consists of fractured dolomitic limestone and bounds the area in its middle and western parts. The maximum altitude is $200 \mathrm{~m}$ above sea level. Many wadis dissecting this plateau, run from South to North.

\section{iv) Hydrographic Basins}

These basins are found mainly in the western part of the study area, from Dabaa and westwards. The wadis gently slope towards the sea or towards the coastal plain. The total number of such wadis has been inventoried by (FAO, 1970) as 218 wadis of different areas and different widths (Tables 1,2).

Table (1). Hydrographic Basins and Wadis at the NWCZ, Egypt.

\begin{tabular}{|c|c|c|c|c|c|}
\hline Region & $\begin{array}{c}\text { No. of } \\
\text { Wadis }\end{array}$ & $\begin{array}{c}\text { Wadis Area } \\
\left.\mathbf{( k m}^{\mathbf{2}}\right) \\
\text { From - to }\end{array}$ & $\begin{array}{c}\text { Total Area } \\
\left.\mathbf{( k m}^{2}\right)\end{array}$ & $\begin{array}{c}\text { Mean } \\
\text { Slope }\end{array}$ & $\begin{array}{c}\text { Mean annual } \\
\text { Rainfall (mm/y) }\end{array}$ \\
\hline $\begin{array}{c}\text { Ras El Dabaa - Ras } \\
\text { Umm El Rakhm }\end{array}$ & 47 & $0.97-148.67$ & 1812.35 & 0.0074 & 210 \\
\hline $\begin{array}{c}\text { Ras Umm El Rakhm - } \\
\text { Sidi Barrani }\end{array}$ & 89 & $0.62-76.89$ & 1505.74 & 0.00503 & 195 \\
\hline Sidi Barrani-El-Sallum & 83 & $0.62-124.35$ & 1409.42 & 0.0188 & 145 \\
\hline
\end{tabular}


Table (2). Specific Annual Runoff for Selected Wadis at the NWCZ, Egypt.

\begin{tabular}{|c|c|c|c|}
\hline Region & $\begin{array}{c}\text { No. of Wadis } \\
\text { with area>10 } \\
\text { km }^{2} \\
\end{array}$ & $\begin{array}{c}\text { Total } \\
\text { Wadis area } \\
\left(\mathbf{k m}^{2}\right) \\
\end{array}$ & $\begin{array}{c}\text { Specific Annual } \\
\text { surface runoff } \\
\left(\mathrm{m}^{3} / \mathrm{km}^{2}\right)\end{array}$ \\
\hline El- Sallum & 14 & 328.11 & 1300 \\
\hline Barrani & 24 & 932.59 & 1000 \\
\hline East Barrani & 14 & 227.74 & 2000 \\
\hline El Negila & 22 & 584.7 & 2000 \\
\hline Umm El Rakham & 12 & 535.37 & 2000 \\
\hline El Kaser & 7 & 419.20 & 2300 \\
\hline Matruh & 14 & 697.02 & 1800 \\
\hline Bakush & 7 & 155.22 & 1300 \\
\hline Fuka & 9 & 446.99 & 900 \\
\hline Total & 123 & 4327.3 & (Av.) 1588 \\
\hline
\end{tabular}

\subsection{Geology}

The study area is essentially dominated by sedimentary rocks of Tertiary and Quaternary ages. The Quaternary deposits are exposed in the coastal plain, wadis and beaches. The Tertiary Pliocene deposits are exposed in the study area, while the Tertiary Miocene forms the surface beds of the plateau. The plateau is formed, essentially of Tertiary Miocene, mainly composed of limestone and dolomite, where it reaches the shoreline at several areas as shown in figure (4) (CONOCO, 1989).

Moreover, the stratigraphic sequence in the study area is illustrated in table (3), (Saleh, 2000).

\subsection{Climate Characteristics}

The climate of the North Western Coastal Zone is characterized by long rainless summer and short rainy winter, from October to April, with limited variation in daily temperature. In general, the zone is related to the Arid or Hyper arid Mediterranean climate. In brief, the mean annual temperature is $19.4{ }^{\circ} \mathrm{C}$, mean relative humidity ranges from $60 \%$ to $70 \%$ and mean wind speed, at $2.0 \mathrm{~m}$ height, ranges from $5.5 \mathrm{~m} / \mathrm{sec}$ to $7.0 \mathrm{~m} / \mathrm{sec}$ in winter and early spring, while in summer decreases to $4.0 \mathrm{~m} / \mathrm{sec}$. 


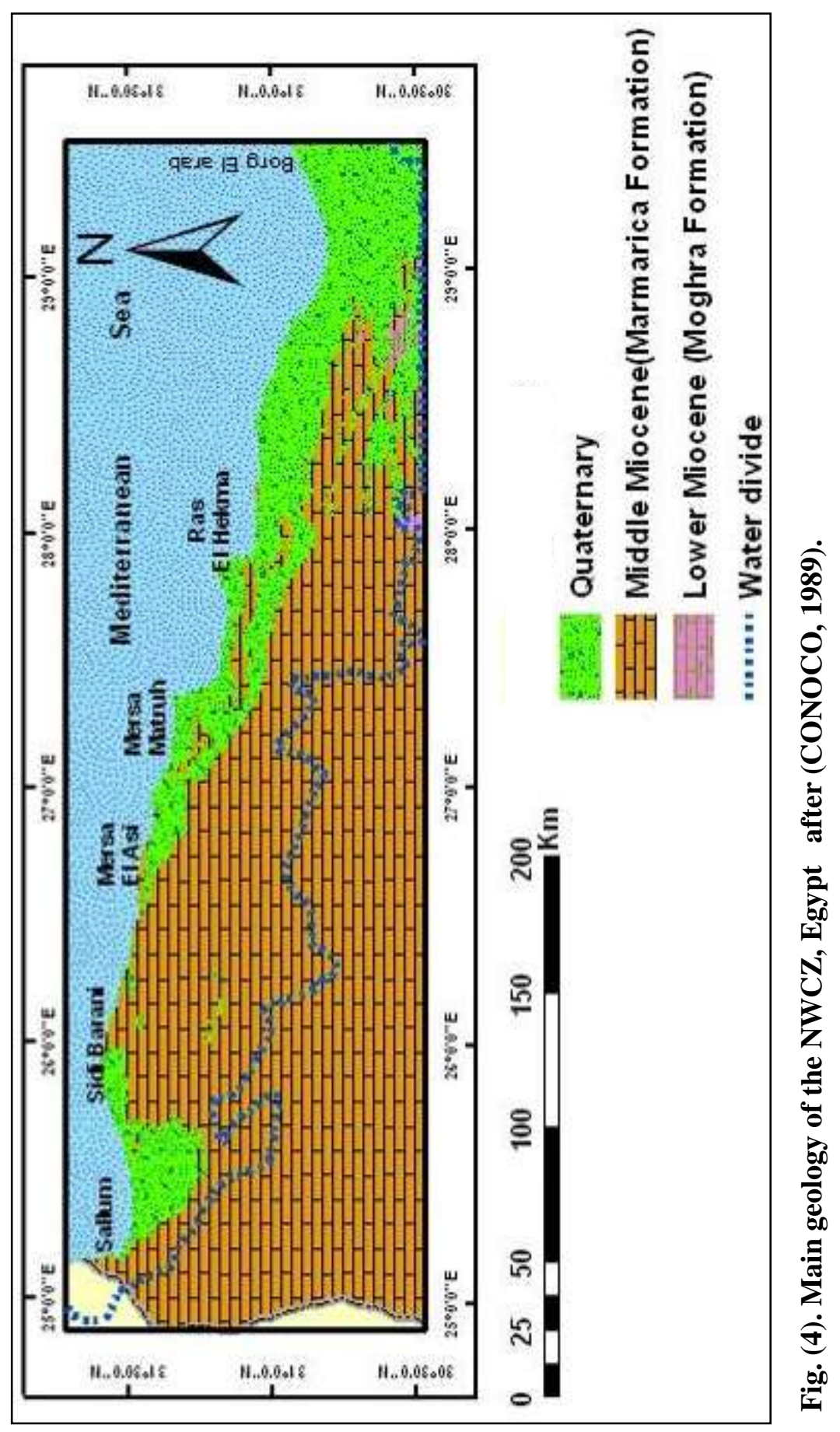

Egyptian J. Desert Res., 59, 1-96 (2009) 
Table (3). Stratigraphic Sequence at the NCWZ, Egypt.

\begin{tabular}{|c|c|c|c|c|c|c|}
\hline \multicolumn{2}{|c|}{ Age } & \multirow[b]{2}{*}{ Lith. } & \multirow[b]{2}{*}{ Stratigraphy } & \multirow[b]{2}{*}{ General Lithologic Description } & \multirow{2}{*}{\begin{tabular}{|c|} 
Max. \\
Appox. \\
Thick. \\
(m)
\end{tabular}} & \multirow[b]{2}{*}{ Hydrogeological setting } \\
\hline Period & Epocl & & & & & \\
\hline \multirow{12}{*}{ 离 } & \multirow{5}{*}{$\frac{\mathscr{\Xi}}{\mathscr{\Xi}}$} & \multirow{5}{*}{\begin{tabular}{|c|}
$V \perp V \perp$ \\
$V \perp V \perp$ \\
$V \perp V \perp$ \\
$V \perp V \perp$ \\
$V \perp V$ \\
$\perp=\perp$ \\
$a \perp=$ \\
$\perp=$ \\
$\perp=$ \\
$1=\perp$ \\
\end{tabular}} & Recent beach & $\begin{array}{l}\text { White loose carbonate sand, fine to very fine } \\
\text { texture mixed with fine quartz grains, shell } \\
\text { fragments. }\end{array}$ & Variable & - \\
\hline & & & \multirow{2}{*}{$\begin{array}{l}\text { Sand dunes } \\
\text { (Coastal and } \\
\text { inland) }\end{array}$} & $\begin{array}{l}\text { Coastal dunes: Composed of loose snow- } \\
\text { white carbonate, always neighboring the } \\
\text { near-shore ridge, its grains similar to those }\end{array}$ & \multirow[b]{2}{*}{30} & $\begin{array}{l}\text { Main aquifer, fresh water } \\
\text { lens floats on top of salt } \\
\text { water. }\end{array}$ \\
\hline & & & & $\begin{array}{l}\text { stretching on the recent beach. } \\
\text { Inland dunes: Composed of loose, yellow to } \\
\text { brown quartz sand, mixed with carbonate } \\
\text { grains, shell fragments. }\end{array}$ & & - \\
\hline & & & $\begin{array}{l}\text { Lagoonal } \\
\text { deposits }\end{array}$ & $\begin{array}{l}\text { Composed of soft reddish brown to brownish } \\
\text { grey carbonaceous loam, high content of } \\
\text { evaporites, spread in the depressions } \\
\text { between the ridges especially near-shore } \\
\text { ridge. }\end{array}$ & \multirow{2}{*}{10} & - \\
\hline & & & $\begin{array}{l}\text { Alluvial } \\
\text { deposits }\end{array}$ & $\begin{array}{l}\text { Composed of pale brown calcareous loam } \\
\text { mixed with gravels, quarts grains and shell } \\
\text { fragments, recorded at the mouth of the } \\
\text { wadies. }\end{array}$ & & $\begin{array}{l}\text { Main aquifer, only reported } \\
\text { in the lower portion of } \\
\text { some drainage lines } \\
\text { dominating from Fuka to } \\
\text { El-Sallum }\end{array}$ \\
\hline & \multirow{5}{*}{ 窇 } & $\begin{array}{l}0000 \\
00000 \\
0000 \\
0000 \\
0000 \\
00000\end{array}$ & $\begin{array}{l}\text { Alexandria } \\
\text { Formation } \\
\text { (Oolitic } \\
\text { limestone } \\
\text { ridges) }\end{array}$ & $\begin{array}{l}\text { Pale brown, hard to moderately hard in older } \\
\text { ridges. While friable in younger ridges, } \\
\text { medium massive bedding, cross bedding } \\
\text { common, upper surface commonly case } \\
\text { hardened, lower sections deconsolidated to } \\
\text { consolidated. }\end{array}$ & 60 & $\begin{array}{l}\text { Main aquifer, widely } \\
\text { distributed in the area of } \\
\text { study, water exists in free } \\
\text { water condition. }\end{array}$ \\
\hline & & \begin{tabular}{|l|}
$V-V$ \\
$-V-V$ \\
\end{tabular} & $\begin{array}{l}\text { Old lagoonal } \\
\text { deposits }\end{array}$ & $\begin{array}{l}\text { Gypsum interbedded with dismicrites and } \\
\text { clayey dismicrites. }\end{array}$ & 32.6 & - \\
\hline & & $\begin{array}{l}-a-s \\
++\dagger\end{array}$ & $\begin{array}{l}\text { Old beach } \\
\text { (Raised } \\
\text { beaches) }\end{array}$ & $\begin{array}{l}\text { Composed of a very hard consolidated } \\
\text { aggregates of shells and gravels cemented } \\
\text { lime. }\end{array}$ & Variable & - \\
\hline & & & $\begin{array}{l}\text { Cardium } \\
\text { limestone }\end{array}$ & $\begin{array}{l}\text { Creamish white, moderately hared rich in } \\
\text { Cardium edule. }\end{array}$ & Variable & - \\
\hline & & & Pink limestone & $\begin{array}{l}\text { Light pink to pale brown, hard and } \\
\text { fragmentary. }\end{array}$ & Variable & - \\
\hline & \multirow{2}{*}{ 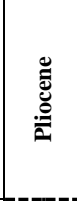 } & & $\begin{array}{l}\text { Creamy } \\
\text { limestone } \\
\text { (Subsurface) }\end{array}$ & Pale yellow, moderately hard fossiliferous. & \multirow[t]{2}{*}{70} & \multirow{2}{*}{$\begin{array}{l}\text { Sec. aquifer, detected in El } \\
\text { Dabaa area in the synclinal } \\
\text { basin between Abo Samra } \\
\text { and El Sira. } \\
\begin{array}{l}\text { Secondary aquifer reported } \\
\text { only in Ghot Rabbah basin } \\
\text { (Matruh area). }\end{array}\end{array}$} \\
\hline & & & $\begin{array}{c}\text { Brown } \\
\text { calcareous s.s. } \\
\text { (Subsurface) }\end{array}$ & Pale brown, fine grained, clayed. & & \\
\hline \multirow[b]{2}{*}{$\stackrel{\Xi}{=}$} & \multirow{2}{*}{ 竞 } & 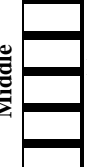 & $\begin{array}{l}\text { Marmarica Fm. } \\
\text { (Surface) }\end{array}$ & $\begin{array}{l}\text { White to pale yellow limestone, } \\
\text { fossiliferous, interbedded with marl and } \\
\text { clay. }\end{array}$ & \multirow{2}{*}{100} & $\begin{array}{l}\text { Main aquifer, has a wide } \\
\text { distribution., exists under } \\
\text { perched condition (Fuka } \\
\text { and El Qataf) and common } \\
\text { main water. }\end{array}$ \\
\hline & & 20208 & $\begin{array}{l}\text { Moghra } \\
\text { Formation } \\
\text { (exposed only } \\
\text { at El-Sallum) }\end{array}$ & $\begin{array}{l}\text { Yellow sandstone, fine to coarse grained, } \\
\text { interrelated with shale and silt. }\end{array}$ & & $\begin{array}{l}\text { Sec. aquifer, exists under } \\
\text { artesian pressure, } \\
\text { piezometric levels between } \\
50 \mathrm{~m} \text { in El-Sallum to sea } \\
\text { level in Burg El Arab }\end{array}$ \\
\hline
\end{tabular}

Egyptian J. Desert Res., 59, 1-96 (2009) 
Winds mostly blow from northwestern direction, while about $25 \%$ of wind comes from southern direction, therefore being hot and dust bearing. The mean annual sunshine is $79 \%$ and reaches its maximum during July and August (about 91\%) and its minimum (68.5\%) during December and January. Evapotranspiration values, determined by Modified Penman equation, are 1450, 1500 and $1600 \mathrm{~mm} /$ year for Sidi Barrani, Matruh and El Dabaa, respectively. Analysis of the directly related climatic elements to the current study can be carried out as follows:

\subsubsection{Rainfall Analysis}

In the current study, rainfall analysis was carried out using data obtained over one hundred years $(1900$ - 2000) from five meteorological stations representing the area, namely; El-Sallum, Sidi Barrani, Mersa Matruh, El Dabaa and Alexandria. Such analysis depended on four parameters: monthly data, annual data, maximum rainfall in one day, number of rainy days based on the variation of the rainfall intensity.

The isohyetal contours of the (NWCZ) during the period (1900 2000) are shown in figure (5) as annual rates. From this figure, the following are noticed:

i) There is a gradual increase in the average annual rainfall from West (El-Sallum) to East (Alexandria) (500 km distance),

ii) There is a gradual increase in the average annual rainfall from South (60 km inland) to North (shore line) $(60-70 \mathrm{~km}$ distance),

iii) The Zero contour line of the average annual rainfall lies at a maximum distance of about $70 \mathrm{~km}$ southward from the shoreline.

Based on the average annual rainfall, data of the whole period (1900 2000) have been used for plotting the graph shown in figure (6) and the following are noticed:

i) The average annual rainfall has been nearly doubled from El-Sallum $(105 \mathrm{~mm})$ the Alexandria $(198 \mathrm{~mm})$ within only $500 \mathrm{~km}$.

ii) The rainfall variability index $(\mathrm{Y})$ of the area has been calculated using the following equation:

$$
\mathrm{Y}=0.15633 * \mathrm{X}+107.96
$$

Where $\mathrm{X}$ is the distance from El-Sallum $(\mathrm{km})$ eastward.

The numbers of rainy days for each meteorological station based on the category of each storm are given in table (4), assuming that the water runoff is caused in case that the storm events is more than 10 $\mathrm{mm}$ for the study area (FAO, 1970).

From the data, which are given in table (4), the following are concluded:

The number of rainy days/year increases considerably from west to east, 


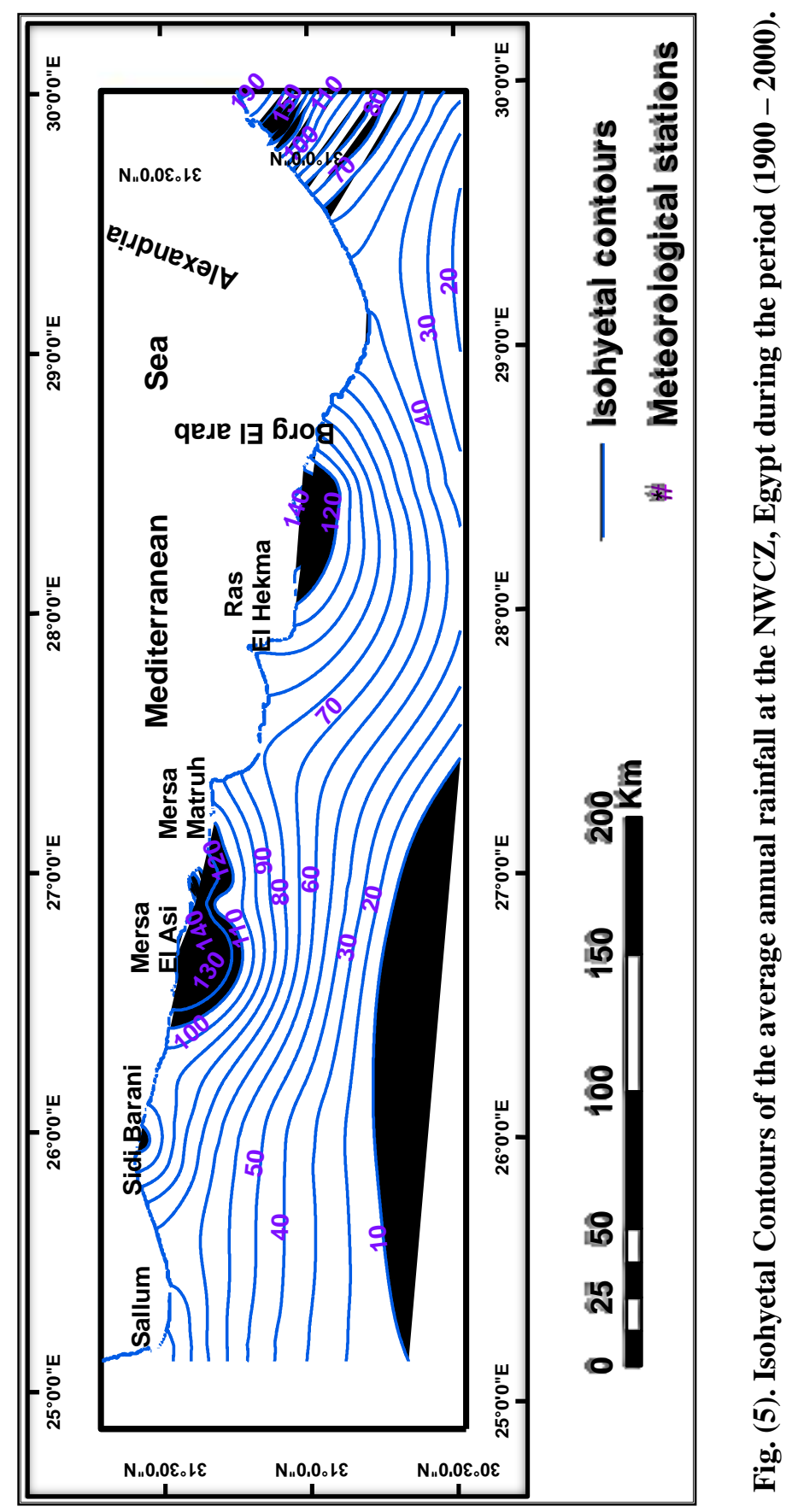

Egyptian J. Desert Res., 59, 1-96 (2009) 


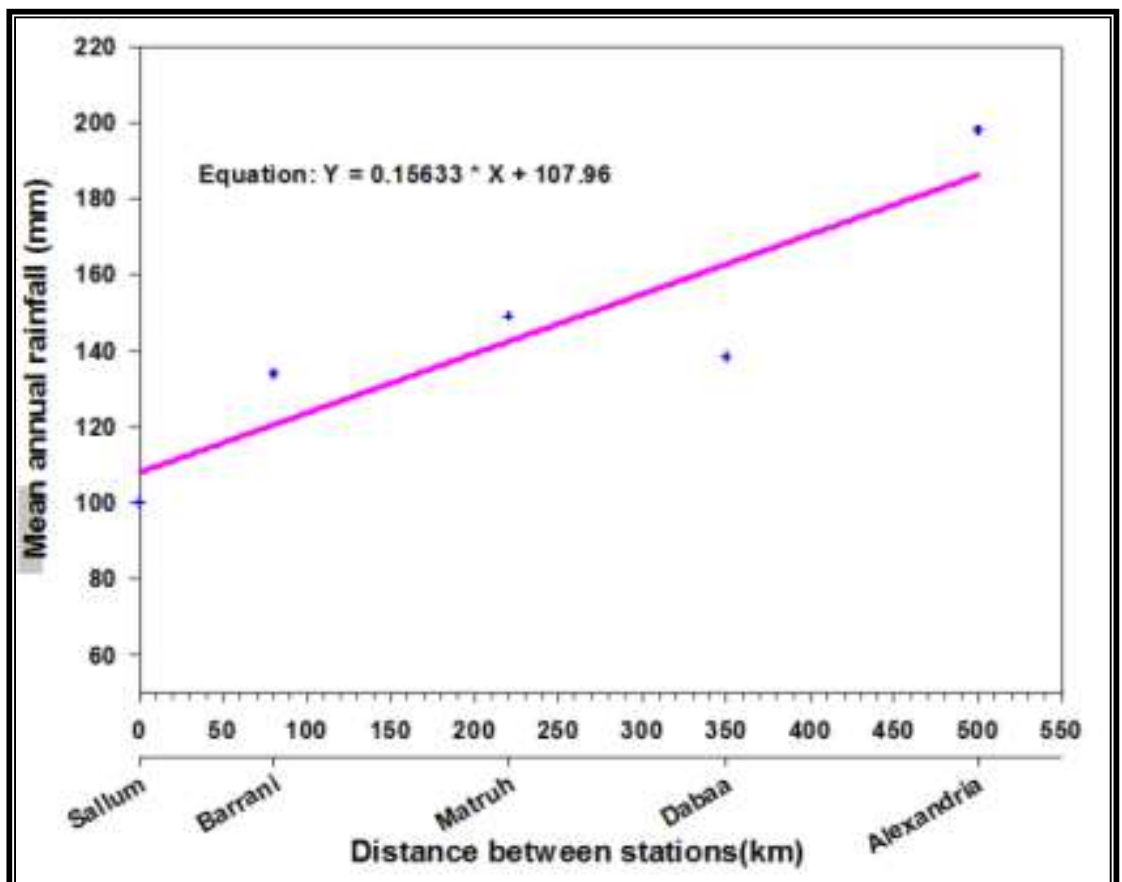

Fig. (6). Variation of the average annual rainfall at the NWCZ, Egypt from West to East of the period $(1900-2000)$.

i) Where there are 53 days at El-Sallum and 95 days in Alexandria (about twice between the latter and the former).

ii) The number of rainy days causing surface runoff (> $10 \mathrm{~mm} / \mathrm{storm})$ reaches about 5 days at Alexandria while it is 2 days at El-Sallum, i.e. it is also doubled from West to East.

In the present work, the same rainfall analysis has been applied to the whole region for 100 years, where the following are concluded: -

i) The ratio between the number of rainy days causing runoff and the total number of rainy days in percentages range between 3\% (ElSallum) and $13 \%$ (Alexandria) depending on the location and physiographic aspect of each meteorological station.

ii) There is a gradual decrease in the number of rainy days from the beginning to the end of last century, ranging between $10 \%$ to $15 \%$.

iii) The number of rainy days rarely exceeds 50 days at El-Sallum, 60 days at Matruh and 80 days at Alexandria.

However, the relationship of the total number of rainy days and the number of rainy days causing surface runoff is well shown in figure (7) for El-Sallum (1955 - 1980) and figure (8) for Alexandria (1900 - 2000). 
Table (4). Number of rainy days for the meteorological stations based on the category of storm events at the NWCZ, Egypt-FAO, 1970.

\begin{tabular}{|c|c|}
\hline station & Annual (days/year) \\
\hline $\begin{array}{l}\text { Alexandria } \\
\text { El Daba'a } \\
\text { Matruh } \\
\text { Sidi Barrani } \\
\text { El Sallum } \\
\end{array}$ & $\begin{array}{l}47.7 \\
24.6 \\
41.9 \\
40.2 \\
31.7 \\
\end{array}$ \\
\hline $\begin{array}{ll} & \mathbf{1 . 0} \mathbf{- 5 . 0} \mathbf{~ m m} \\
\text { Alexanarıa } & \\
\text { El Daba'a } & \\
\text { Matruh } & \\
\text { Sidi Barrani } & \\
\text { El Sallum } & \end{array}$ & $\begin{array}{l}30.2 \\
17.1 \\
23.1 \\
25.1 \\
14.1\end{array}$ \\
\hline $\begin{array}{l}\text { Alexanaria } \\
\text { El Daba' } \mathbf{5 . 0} \mathbf{~ m m} \\
\text { Matruh } \\
\text { Sidi Barrani } \\
\text { El Sallum } \\
\end{array}$ & $\begin{array}{l}11.7 \\
8.0 \\
7.3 \\
8.7 \\
5.2 \\
\end{array}$ \\
\hline $\begin{array}{l}\text { Alexa } \\
\text { El Daba'a } \\
\text { Matruh } \\
\text { Sidi Barrani } \\
\text { El Sallum }\end{array}$ & $\begin{array}{l}5.2 \\
4.0 \\
3.1 \\
3.8 \\
2.2\end{array}$ \\
\hline $\begin{array}{l}\text { Alexandria } \\
\text { El Daba'a } \\
\text { Matruh } \\
\text { Sidi Barrani } \\
\text { El Sallum }\end{array}$ & $\begin{array}{l}94.8 \\
53.7 \\
75.4 \\
77.8 \\
53.2\end{array}$ \\
\hline
\end{tabular}

Egyptian J. Desert Res., 59, 1-96 (2009) 


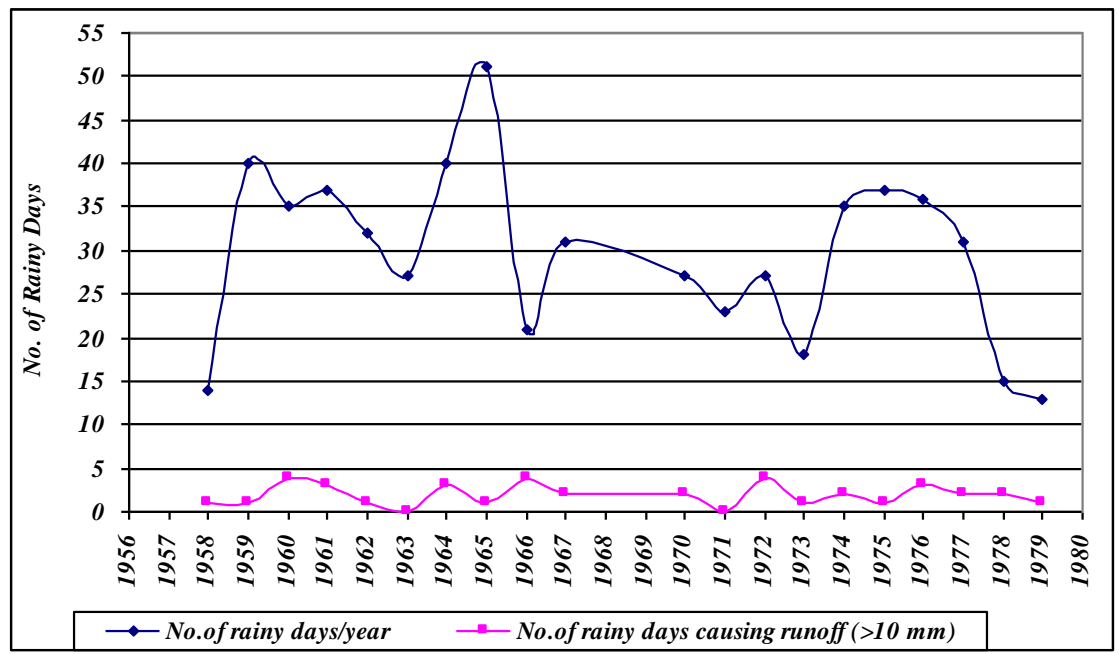

Fig. (7). Count of total rainy days/year and rainy days causing runoff/year for El- Sallum station at the NWCZ, Egypt.

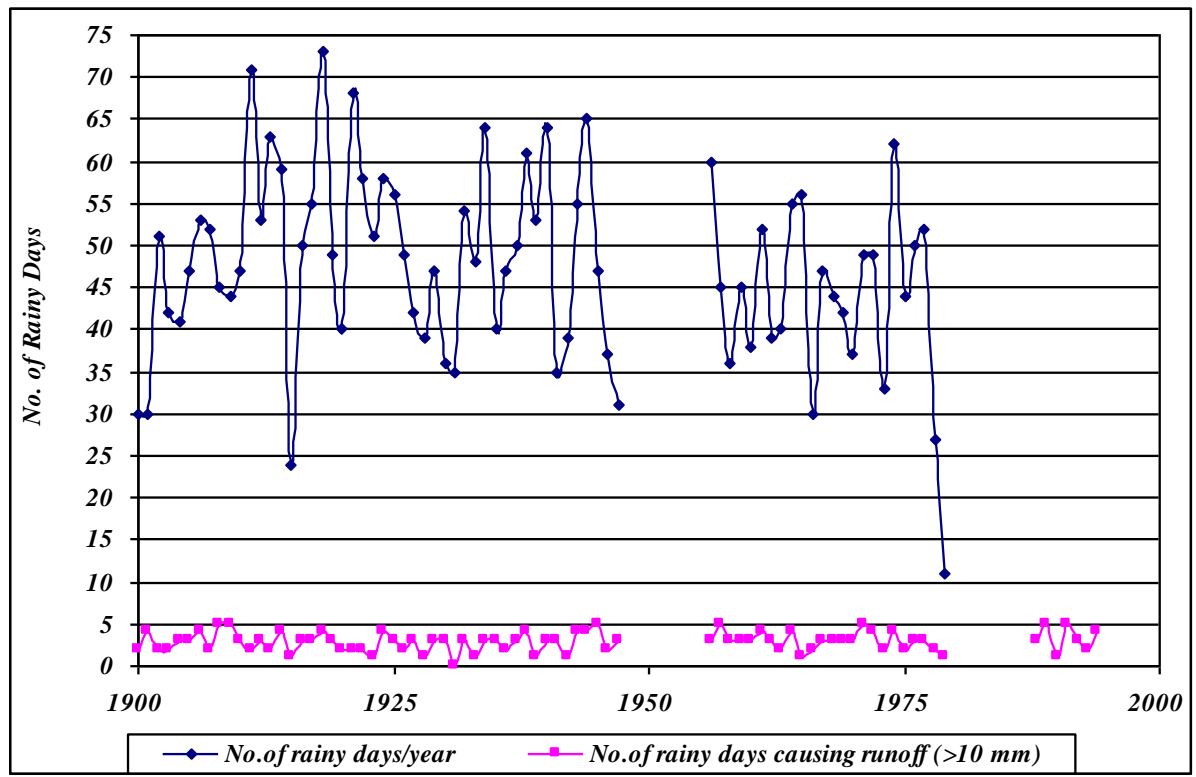

Fig. (8). Count of total rainy days/year and rainy days causing runoff/year for Alexandria station at the NWCZ, Egypt. 


\subsubsection{Evapotranspiration}

In this study, Thornthwaite equation was chosen to calculate the evapotranspiration in the study area (Thornthwaite, 1948).

Where

$$
\mathrm{PET}=16\left[\frac{10 T}{I}\right]^{a}
$$

$\mathrm{PET}=$ Monthly potential evapotranspiration in $\mathrm{mm}$

$\mathrm{T}=$ Monthly mean temperature in ${ }^{\circ} \mathrm{C}$

$a$ = Location dependent coefficient described by the following equation

$$
a=6.75 \times 10^{-7} I^{3}-7.71 \times 10^{-5} I^{2}+1.792 \times 10^{-2} I+0.49239
$$

$I=$ Heat Index described by the following equation (it is constant for a given location)

Where

$$
I=\sum_{j=1}^{12}\left[\frac{T_{j}}{5}\right]^{1.514}
$$

$\mathrm{T} j$ is the mean monthly temperature during month $j\left({ }^{\circ} \mathrm{C}\right)$

The data in table (5), show that the summer season (June to August) has the maximum evapotranspiration $(16.69 \mathrm{~mm})$, while the minimum rate was noticed in winter season (December to February), $2.66 \mathrm{~mm}$.

Table (5). Calculated Potential Evapotranspiration (mm) at the NWCZ, Egypt - Using Thornthwaite Equation, 1948.

\begin{tabular}{|c|c|c|c|c|c|}
\hline Month & El-Sallum & Sidi-Barrani & Matruh & El-Dabaa & Alexandria \\
\hline Jan. & 3.00 & 2.81 & 2.83 & 2.74 & 2.86 \\
\hline Feb. & 3.23 & 2.77 & 2.93 & 2.66 & 3.01 \\
\hline Mar & 4.82 & 4.46 & 4.35 & 4.34 & 4.90 \\
\hline Apr & 6.93 & 6.06 & 6.31 & 6.22 & 7.08 \\
\hline May & 9.88 & 8.58 & 8.77 & 9.07 & 10.02 \\
\hline Jun & 13.47 & 11.50 & 11.84 & 12.39 & 13.63 \\
\hline Jul & 15.67 & 13.95 & 13.90 & 14.64 & 16.18 \\
\hline Aug & 15.08 & 14.34 & 13.96 & 14.67 & 16.69 \\
\hline Sep & 11.77 & 11.70 & 11.59 & 11.93 & 13.45 \\
\hline Oct & 9.66 & 8.93 & 9.38 & 9.20 & 10.62 \\
\hline Nov & 5.93 & 6.07 & 5.91 & 5.95 & 6.47 \\
\hline Dec & 3.30 & 3.44 & 3.22 & 3.25 & 3.43 \\
\hline
\end{tabular}


On bases of the climatic data of the (NWCZ), the Water Deficit and Water Surplus were given, using the relation between the monthly precipitation $(\mathrm{P})$ and monthly potential evapotranspiration (PET) as shown in figures $(9,10)$.

From the figures $(9,10)$, the following are concluded:

i) In winter season (December to February), there is a surplus of water that may satisfy the water requirements of the growing crops.

ii) In March and October, there is a marginal water resources, where groundwater is needed as a supplemental source for irrigation.

iii) In summer and springs seasons (April - October), there is a deficit of water resources, where groundwater is almost the only source for crop irrigation with increasing demand in June, July and August.

iv) The water deficit in the east of Matruh is of considerable amount compared with that of west Matruh.

\subsubsection{Wind Speed and direction}

Data in table (6) give the average wind velocity $(\mathrm{km} / \mathrm{hr})$ of the five selected meteorological stations based on monthly measurements. From this table, the following are noticed:

- The highest average wind speed $(24.9 \mathrm{~km} / \mathrm{hr})$ was recorded in January at Matruh localities, while the lowest wind speed is $11.5 \mathrm{~km} / \mathrm{hr}$ in November at El- Dabaa station.

- The highest average wind speed $(22-22.9 \mathrm{~km} / \mathrm{hr})$ was recorded in the winter season (December - February), while in the summer season it rarely exceeds $18 \mathrm{~km} / \mathrm{hr}$.

- The wind direction in the area, as shown in figures $(11,12)$ indicates that about $75 \%$ of the wind comes from the North and North West in winter season, while 25\% comes from the South and South West, while in summer season, $65 \%$ of the wind blows from the south and the southwest.

- The wind comes from North and Northwest direction in winter season carries rainfall, while that comes from south in summer season causes soil erosion, especially in the plateau territory.

\subsection{Water Resources \\ 1.5.1. Surface Runoff}

To evaluate the rainfall - runoff relationship for the major wadis in the area between Dabaa and El-Sallum, the data of the storm rainfall $(\mathrm{x}, \mathrm{mm})$ versus runoff volume $\left(\mathrm{y}, \mathrm{m}^{3}\right)$, storm rainfall $(\mathrm{x}, \mathrm{mm})$ and runoff depth $\left(y, \mathrm{~m}^{3}\right)$ has been statistically correlated and illustrated graphically in figure (13). 


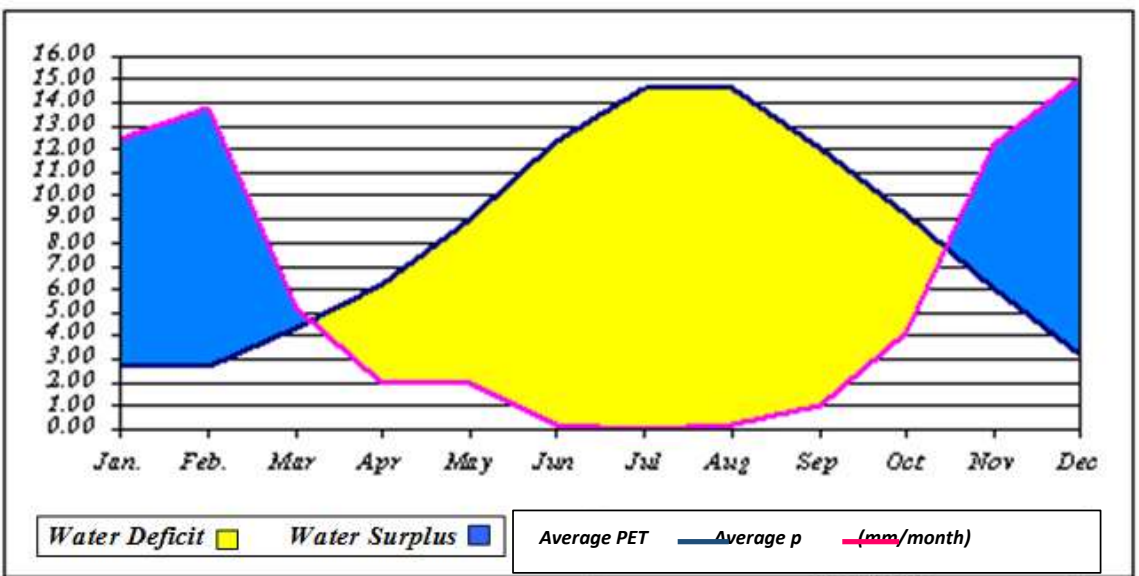

Fig. (9). Relation between water deficit and water surplus at East Matruh area at the NWCZ, Egypt.

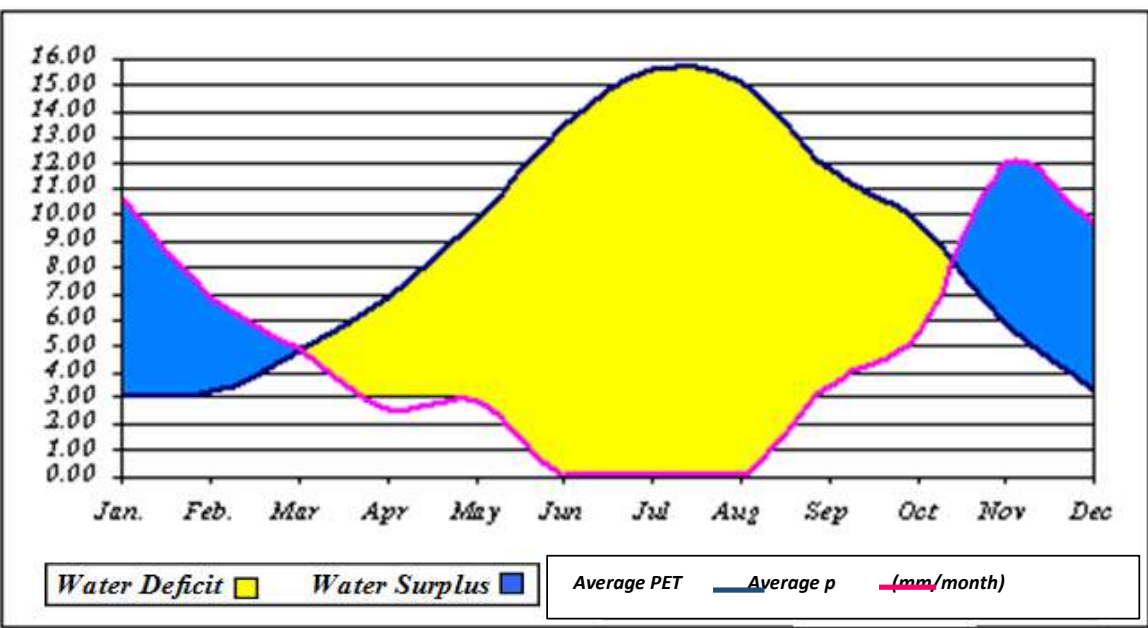

Fig. (10). Relation between water deficit and water surplus at West Matruh area at the NWCZ, Egypt.

Egyptian J. Desert Res., 59, 1-96 (2009) 
Table (6). Average Wind Speed $(\mathrm{km} / \mathrm{hr})$ at the NWCZ, Egypt.

\begin{tabular}{|c|c|c|c|c|c|}
\hline Station & Alexandria & $\begin{array}{c}\text { El } \\
\text { Dabaa }\end{array}$ & Matruh & $\begin{array}{c}\text { Sidi } \\
\text { Barrani }\end{array}$ & $\begin{array}{c}\text { El- } \\
\text { Sallum }\end{array}$ \\
\hline Janth. & 17 & 13.1 & 24.9 & 20.4 & 15.9 \\
\hline Feb. & 17.2 & 14.1 & 23.3 & 20.2 & 14.5 \\
\hline Mar & 18.2 & 15.9 & 22.8 & 21.5 & 14.8 \\
\hline Apr & 16.7 & 16.3 & 22.6 & 20.6 & 13.5 \\
\hline May & 15.4 & 15.8 & 20.0 & 18.2 & 11.9 \\
\hline Jun & 16.5 & 16.3 & 19.3 & 17.0 & 13.7 \\
\hline Jul & 15.9 & 18.0 & 21.4 & 20.0 & 15.4 \\
\hline Aug & 15.7 & 16.5 & 18.7 & 17.2 & 14.1 \\
\hline Sep & 14.4 & 13.5 & 17.8 & 15.7 & 12.0 \\
\hline Oct & 12.6 & 12.8 & 16.3 & 15.7 & 11.9 \\
\hline Nov & 13.0 & 11.5 & 17.4 & 16.5 & 12.8 \\
\hline Dec & 15.9 & 14.5 & 22.0 & 19.8 & 16.5 \\
\hline
\end{tabular}

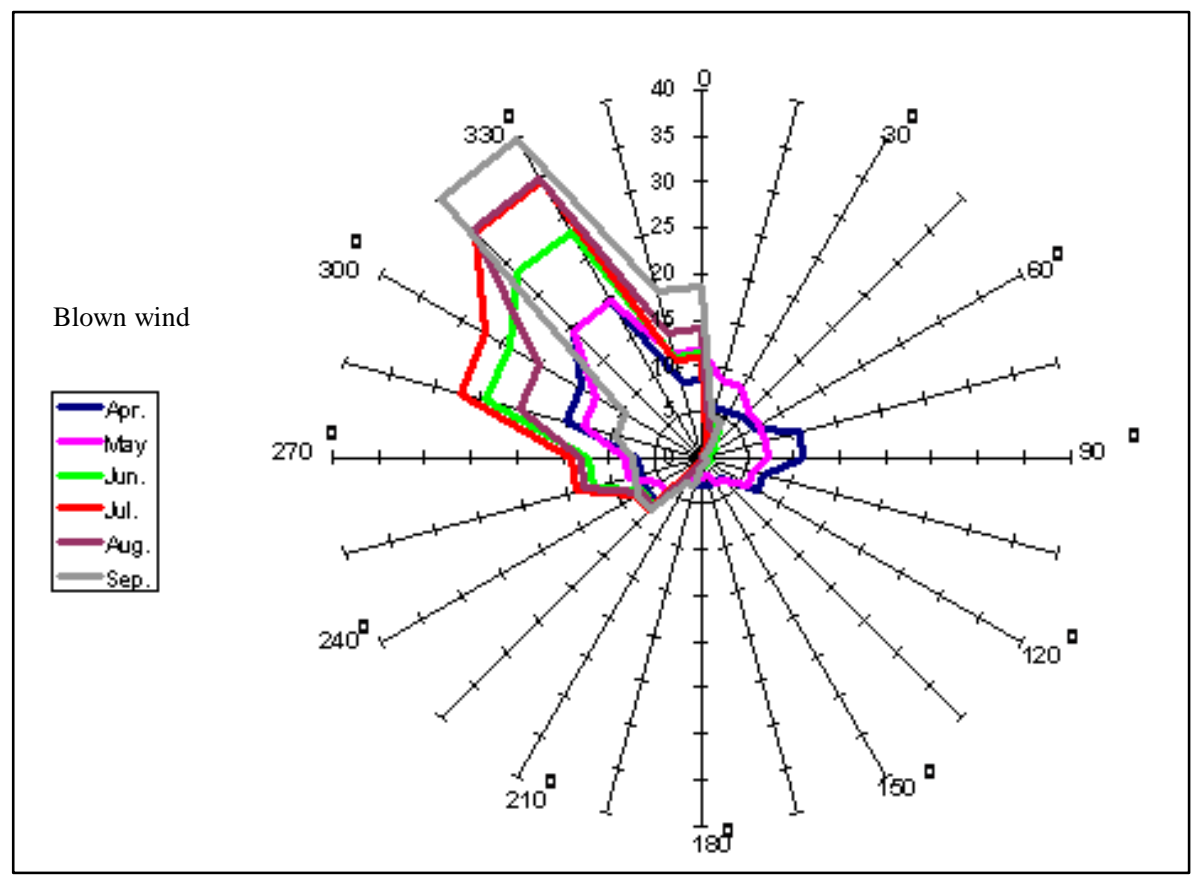

Fig. (11). Rose Diagram of wind direction (winter season) at the NWCZ, Egypt. 


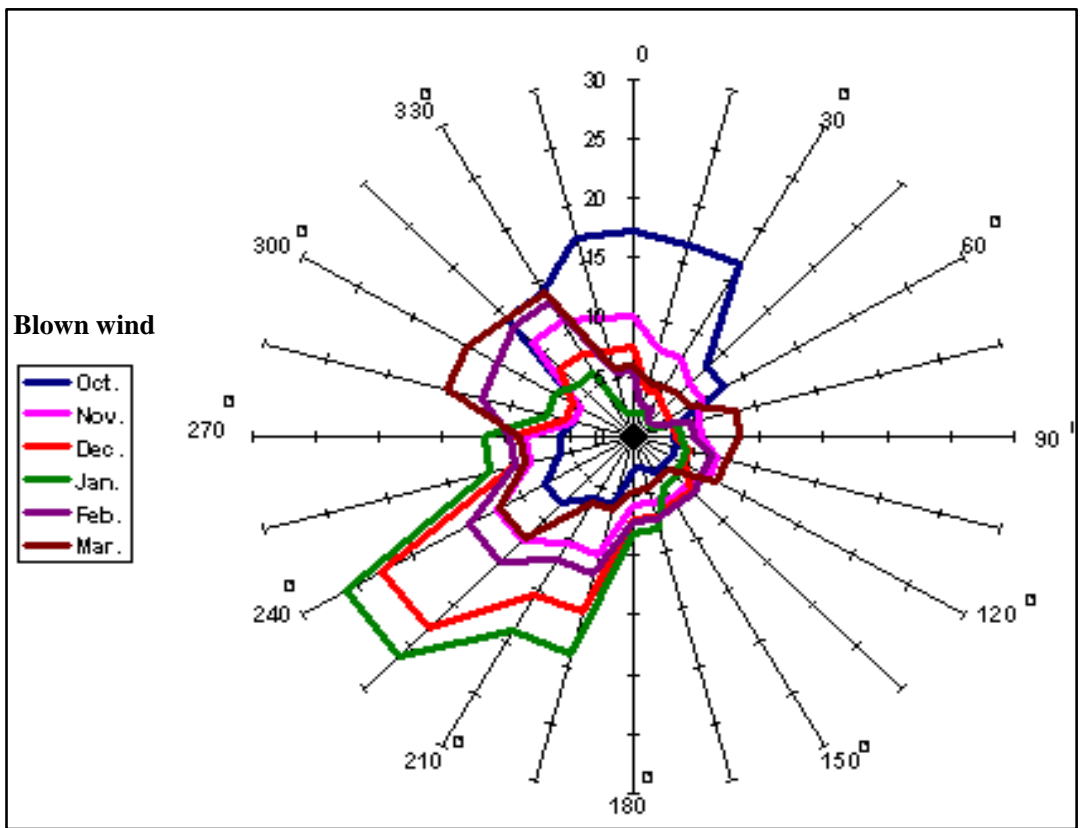

Fig. (12). Rose Diagram of wind direction (summer season) at the NWCZ, Egypt.

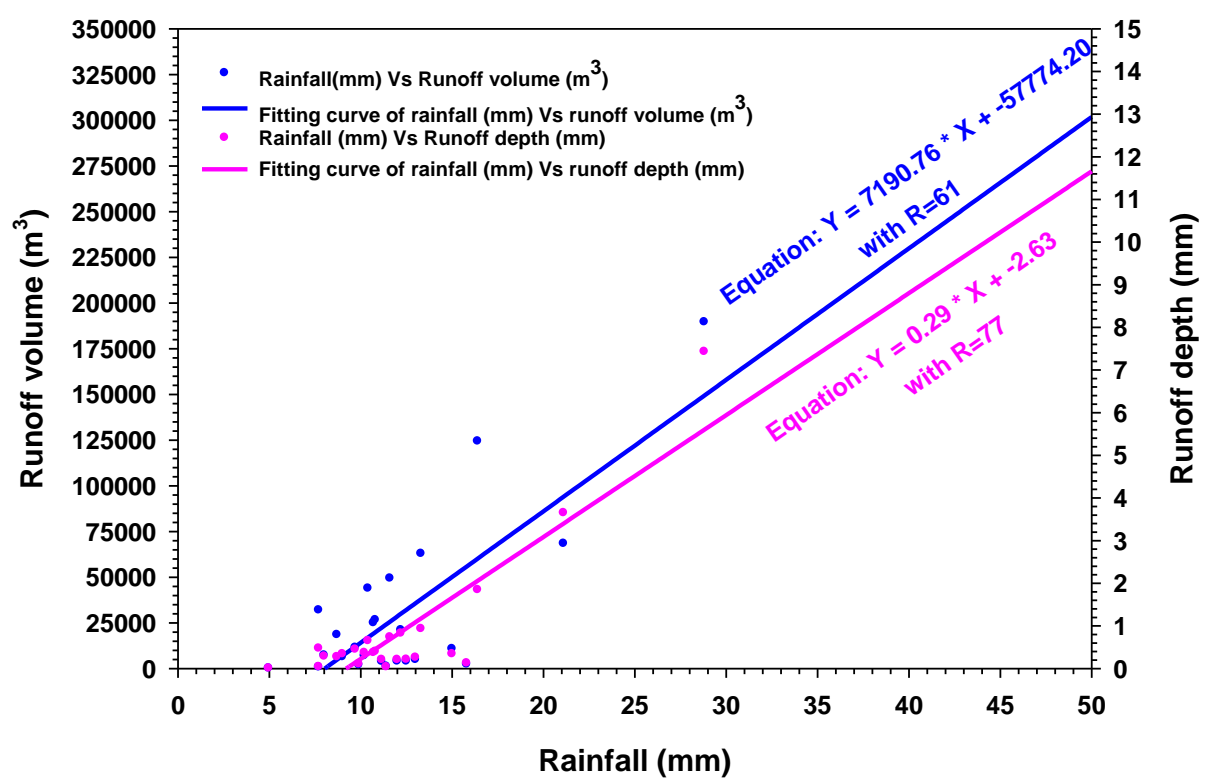

Fig. (13). Rainfall - Runoff relationship for the Wadis from Dabaa to El-Sallum area at the NWCZ, Egypt (Zaki, 2000).

Egyptian J. Desert Res., 59, 1-96 (2009) 
The following can be concluded:

- There is a linear relationship between the amount of rainfall ( $\mathrm{mm})$ and each of runoff volume $\left(\mathrm{m}^{3}\right)$ and runoff depth $(\mathrm{mm})$ as shown from the equation given in the figure.

- In case of a rainfall storm of an amount of $10 \mathrm{~mm}$, the corresponding specific surface runoff (overland flow) will be equal to about $270 \mathrm{~m}^{3} / \mathrm{km}^{2}$. However, the rainfall storm of $20 \mathrm{~mm}$ will result a specific surface runoff (overland flow) of about $3150 \mathrm{~m}^{3} / \mathrm{km}^{2}$.

- The average specific surface runoff in this area has been estimated by UNSCO (1995) to be $1588 \mathrm{~m}^{3} / \mathrm{km}^{2}$. This value is quite matching with the calculated values. It corresponds to a rainfall storm of about 15 $\mathrm{mm}$, which is very common in the study area.

\subsubsection{Groundwater Analysis}

In general, groundwater aquifers could be distinguished into two groups, namely:

a) Quaternary aquifer (Pleistocene), which is formed of disintegrated calcareous deposits that extend parallel to the sea shore along the whole region from Burg El-Arab to El-Sallum. This aquifer is characterized by its ability to be charged from seasonal rainfall water due to its porosity and higher permeability and in most cases its groundwater is fresh to brackish.

b) Fractured limestone aquifer (mid. Miocene), which covering entirely Marmarica plateau), was not exploited until the year 2008 but the prevailing aridity during the last years necessitates its use as a supplementary source for irrigation purposes.

A survey and an evaluation of 131 wells dissecting the Quaternary and mid Miocene aquifers were carried out. These wells are distributed along the Northwestern Coastal Zone from El-Sallum to El-Dabaa and extend southwards to about $40 \mathrm{~km}$, where some tens of wells reaching an elevation of about $150 \mathrm{~m}$ a.s.l. were recorded.

The groundwater levels in accordance with sea water levels were worked out and recorded, (Figure 14). The groundwater level in the region is either above sea level ( $80 \%$ of wells) or below sea level ( $20 \%$ of wells).

It is also apparent that most wells having water level below sea water are located within the coastal area (Sidi Barrani - West Marsa El-Asy) beside some inland wells, far from the sea shore mostly in the coastal depressions. It is also noticed that saline groundwater is generally concentrated in areas having groundwater level below sea level but the moderately saline groundwater is usually confined to areas having groundwater level higher than sea water one. 


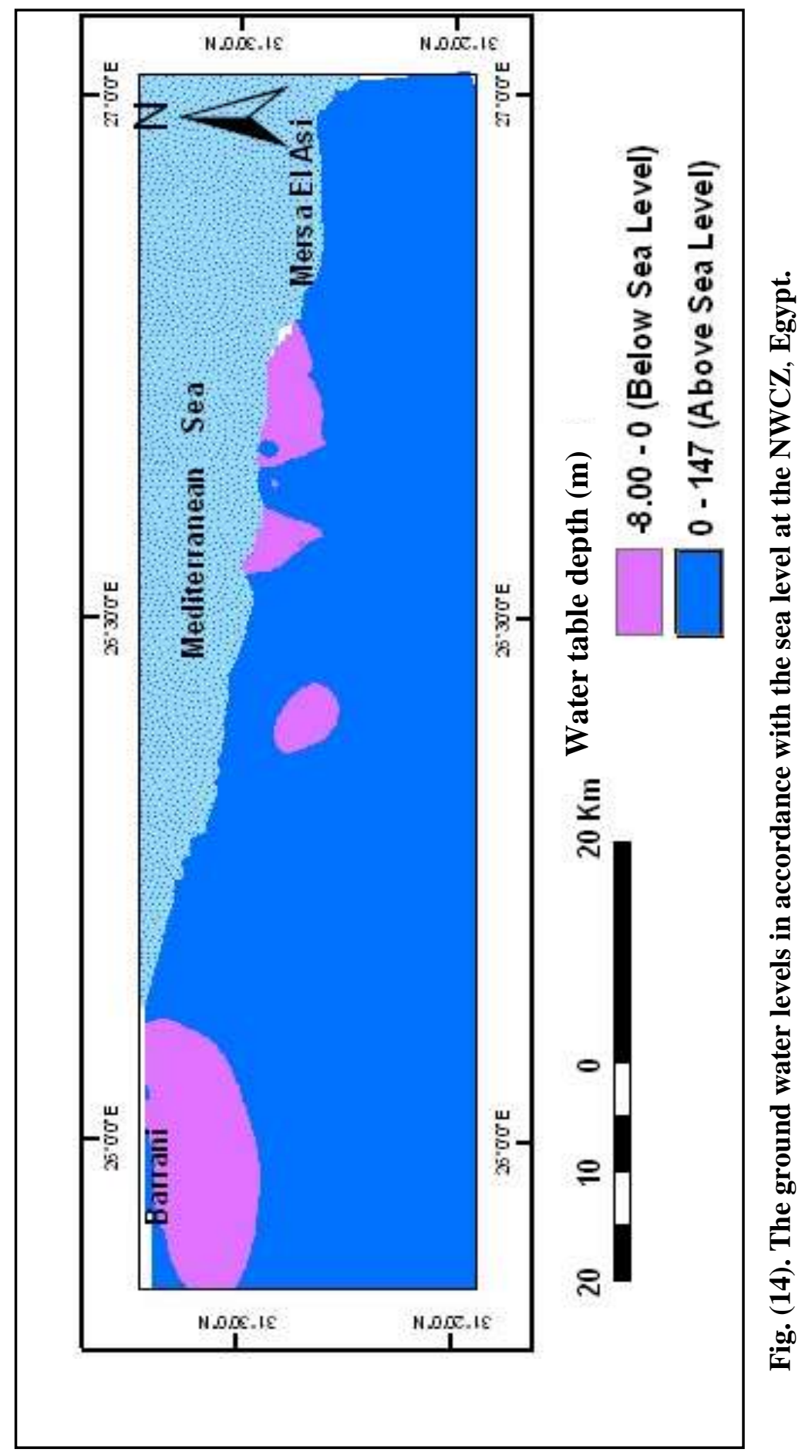

Egyptian J. Desert Res., 59, 1-96 (2009) 
Considering the recorded groundwater salinity of the aquifers related to the Quaternary and Tertiary, data revealed three salinity ranges or groups, (Figures 15, 16) as follows:

i. Group 1, includes water attaining less than $5000 \mu \mathrm{S} \mathrm{cm} \mathrm{c}^{-1}$ which represents about 5\% of wells east Matruh while rises up to about $50 \%$ west Matruh especially in Barrani area. This controversy should be considered in a detailed study for initiating future developmental approaches for combating desertification.

ii. Group 2, includes wells having water salinity ranges between 5000 and $10000 \mu \mathrm{Scm}^{-1}$, this group represents more than $50 \%$ of wells east Matruh and 30\% of wells west Matruh to Sidi Barrani

iii. Group 3, includes wells having water salinity more than $10000 \mu \mathrm{Scm}^{-1}$, which form about $20 \%$ of wells west Matruh to Sidi Barrani, while the rest of wells that their salinity $>10000 \mu \mathrm{Scm}^{-1}$ are at to the east of Barrani.

It worth to mention that groundwater having salinity of about 700 $\mu \mathrm{Scm}^{-1}$ and suitable for drinking is found in both Ras El-Hekma and Sedi Shebib, $112 \mathrm{~km}$ east Matruh, south the main road, this case is currently investigated to find its cause and distribution pattern in the concerned areas.

\subsection{Natural Vegetation and Agricultural Crops}

Natural vegetation is the most affected ecological elements by desertification. It can be considered the first indicator of desertification degree. Natural plant cover is considered as a renewable natural resource. Its floristic composition depends upon the natural conditions, biotic and management factors. Occurrence of plant communities clearly points to the dominant ecological conditions including climatic, geomorphologic and other effective conditions. Data in table (7) show the areas with different plant cover in five sectors at the NWCZ extending from Fuka in the east to El-Sallum westward, while that in table (8), show the percentage ratios of each vegetation type in each sector of the transected area in addition to the total vegetation area relative to the total area (MDCMR, 2009).

Taking into consideration that the area of study is extend to 2.7 million feddan to cover most of the vegetation types. This area is distributed on five sectors, from east to west; Ras El-Hekma, Mersa Matruh, El-Negila, East Sidi Barrani and West Sidi Barrani.

The plant cover can be discriminated into seven types:

1. Lightly covered rangelands.

2. Moderately covered rangelands.

3. Densely covered rangelands.

4. Fruit trees (Cultivated olive, figs, grape, ..... etc.)

5. Sandy and rocky plants.

6. Salt marshes plants. 
7. Crops (mainly barley and wheat).

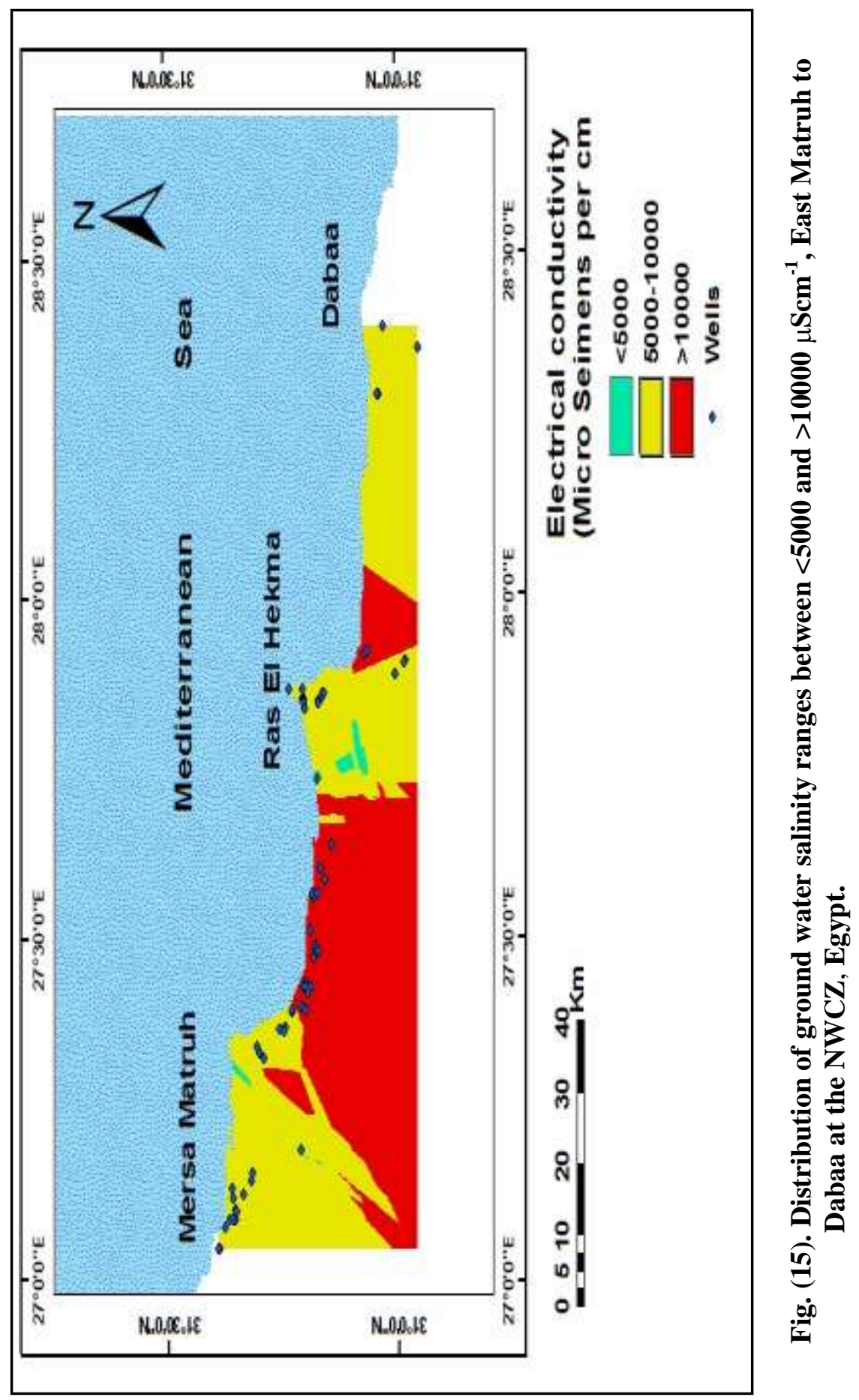

Egyptian J. Desert Res., 59, 1-96 (2009) 


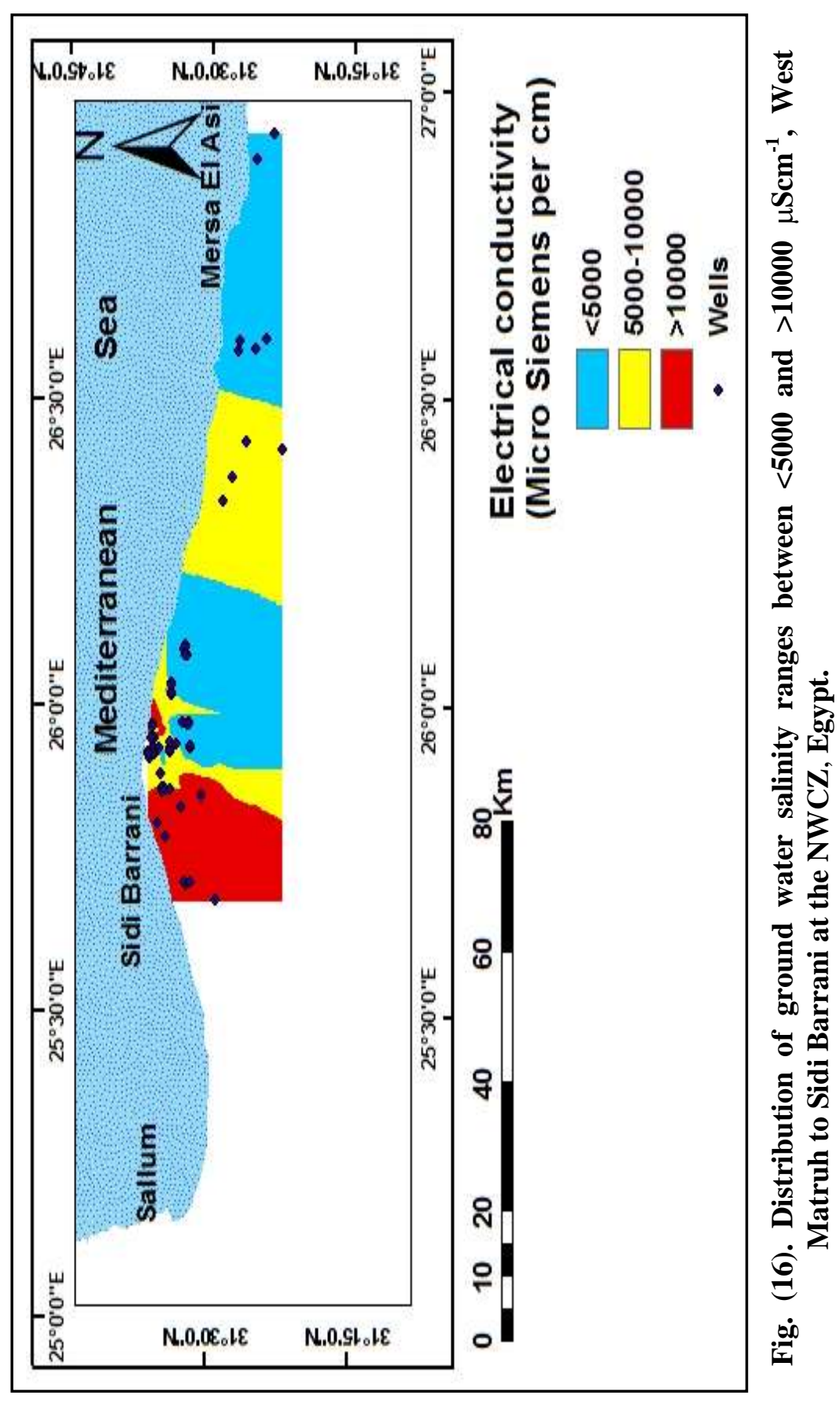

Egyptian J. Desert Res., 59, 1-96 (2009) 
Table (7). Areas in feddan of the vegetation types Distributed at the NWCZ, Egypt.

\begin{tabular}{|c|c|c|c|c|c|c|c|}
\hline Class name & $\begin{array}{c}\text { Ras } \\
\text { El- Hekma }\end{array}$ & $\begin{array}{c}\text { Mersa } \\
\text { Matruh }\end{array}$ & Negila & $\begin{array}{c}\text { East } \\
\text { Barrani }\end{array}$ & $\begin{array}{c}\text { West } \\
\text { Barrani }\end{array}$ & Total & $\begin{array}{c}\text { Total } \\
(\%)\end{array}$ \\
\hline Unclassified & 16426 & 63737 & 81171 & 1853 & 6582 & 169769 & 6.2 \\
\hline Light Range & 99694 & 262620 & 411085 & 22119 & 337368 & 1132886 & 41.3 \\
\hline Moderate Range & 49152 & 118544 & 271640 & 209774 & 292994 & 942104 & 34.3 \\
\hline Dense Range & 7740 & 56919 & 45791 & 57914 & 21254 & 189618 & 6.9 \\
\hline Fruit trees & 7649 & 10798 & 7424 & 51203 & 21606 & 98680 & 3.6 \\
\hline Sand\& Rock plants & 33018 & 21397 & 1156 & 851 & 8002 & 64424 & 2.3 \\
\hline Salt Marshes plants & 157 & 2221 & 748 & 1121 & 14803 & 19050 & 0.7 \\
\hline Crops & 10198 & 33859 & 37876 & 25339 & 20852 & 128124 & 4.7 \\
\hline Total & 224034 & 570095 & 856891 & 370174 & 723461 & 2744655 & 100 \\
\hline
\end{tabular}

Table (8). Percentage of Vegetation Area at the NWCZ, Egypt.

\begin{tabular}{|c|c|c|c|c|c|c|}
\hline Class name & $\begin{array}{c}\text { Ras } \\
\text { El-Hekma }\end{array}$ & $\begin{array}{c}\text { Mersa } \\
\text { Matruh }\end{array}$ & Negila & $\begin{array}{c}\text { East } \\
\text { Barrani }\end{array}$ & $\begin{array}{c}\text { West } \\
\text { Barrani }\end{array}$ & Total (\%) \\
\hline Unclassified & 7.3 & 11.2 & 9.5 & 0.5 & 0.9 & 6.2 \\
\hline Light Range & 44.5 & 46.1 & 48.0 & 6.0 & 46.6 & 41.3 \\
\hline Moderate Range & 21.9 & 20.8 & 31.7 & 56.7 & 40.5 & 34.3 \\
\hline Dense Range & 3.5 & 10.0 & 5.3 & 15.6 & 2.9 & 6.9 \\
\hline Fruit trees & 3.4 & 1.9 & 0.9 & 13.8 & 3.0 & 3.6 \\
\hline Sand\& Rock plants & 14.7 & 3.8 & 0.1 & 0.2 & 1.1 & 2.3 \\
\hline Salt Marshes plants & 0.1 & 0.4 & 0.1 & 0.3 & 2.0 & 0.7 \\
\hline Crops & 4.6 & 5.9 & 4.4 & 6.8 & 2.9 & 4.7 \\
\hline Total & 100 & 100 & 100 & 100 & 100 & 100 \\
\hline
\end{tabular}

From the data in tables 7 and 8, the following can be concluded:

- There are some areas that were not studied or classified and occupy nearly 170 thousand feddans.

- Most common areas of the coast are covered with light ranges, which represent approximately $41.3 \%$ of the total sectors. Such ranges are highly represented in all sectors $(44.5-48.0 \%)$. East Sidi Barrani is an exceptional case where the light ranges represent (6.0\%).

- Moderate Ranges represent about 34.3\% (942, 104 feddan) of the total area, where the highest percentage was recorded in East Sidi Barrani, $(56.7 \%)$ of the total sector area, followed by West Barrani sector $(40.5 \%)$. This may be attributed to the occurrence of most area in contour lines to the north of the other sectors where the rainfall is 
higher. The less dominant moderate ranges is occurred at El-Negila sector $(31.7 \%)$, where the least dominant one is at Matruh sector $(20.8 \%)$.

- Area covered with dense ranges is about 190,000 feddans, representing only $6.9 \%$ of the total sectors' areas. The highest percentage was recorded also at East Sidi Barrani sector followed by Matruh sector. The lowest percentage was recorded at West Sidi Barrani.

- Fruit trees (olives, figs ...etc.) occupied about 36,000 feddans which representing about $3.6 \%$ of the total sectors' areas. Half (50\%) of these areas are occurred at East Sidi Barrani sector (13.8\%) followed by Ras El-Hekma (3.4\%). The smallest area lies in West Sidi Barrarni sector $(2.9 \%)$. On the level of the total area of the sectors, crops are cultivated on $2.3 \%$ of the total sectors 'areas.

- Sand and Rock plants represent about 2.3\% of the total sectors' areas. Most of these plants are existed at Ras El-Hekma sector (14.7\%).

- Salt marshes exist along the coast, though occupy relatively lower areas compared to the other plant cover, they represent $0.7 \%$ of the total sectors 'areas with their higher percentage (2\%) is occurred at West Sidi Barrani.

- The NWCZ is the richest phytogeographical region of Egypt. The number of recorded species is about 1054 (khedr, 2006), though drought spells in addition to the unwise exploitation and overgrazing resulted in the deterioration of natural plant cover and the disappearance of many endemic and rare species (Heneidy, 2002).

Accordingly, the plant cover type differs from an area to another with variations in available moisture content (water resources) and soil type. In some areas or sites, fruit trees (fig, olive and grape), can be cultivated whereas others are suitable for crops (barley and wheat). In other areas (most common) range plants can be exploited. Other range plants cover sandy and rocky areas and even sand dunes and dry salt marshes.

\section{2- USE OF REMOTE SENSING AND (GIS) IN MAPPING DESERTIFICATION SENSITIVITY AREAS}

The integration of Remote Sensing and Geographic Information System (GIS) is one of the most valuable tools for assessing and monitoring the natural resources degradation as well as the man-made activities which are the main factor causing desertification (anthropogenic factor).

Developing a model to define and quantitatively assesses the desertification sensitivity in the desert areas will help in understanding aspects of desertification and support the decision makers to establish the 
successful sustainable development. Through this model, the quantitative evaluation of the desertification sensitivity and then mapping of the environmentally sensitive areas (ESAs) to desertification can be satisfactorily conducted.

\subsection{Image processing and analysis}

Image processing and analysis can be defined as the "act of examining images for the purpose of identifying objects and judging their significance". Image analyst study the remotely sensed data and attempt through logical process in detecting, identifying, classifying, measuring and evaluating the significance of physical and cultural objects, their patterns and spatial relationship.

In the present work a number of 9 scenes of SPOT 4 satellite images were used to study the natural resources as well as the desertification process along the study area. The date of the images was 18/11/2008. The paths (Raw No. and Column No.) of these images are:

\begin{tabular}{|c|c|c|c|c|c|c|c|c|c|}
\hline Raw No. & 99 & 100 & 101 & 102 & 103 & 104 & 105 & 106 & 107 \\
\hline Column No. & 287 & 287 & 287 & 287 & 287 & 288 & 288 & 288 & 288 \\
\hline
\end{tabular}

Erdas Imagine Software Ver.9.2 was used to make the different image processing and analysis.

Digital image processing is a collection of techniques for the manipulation of digital images by computers. The raw data received from the imaging sensors on the satellite platforms contain flaws and deficiencies. To overcome these flaws and deficiencies in order to get the originality of the data, it needs to undergo several steps of processing. This will vary from one image to another depending on the type of image format, initial condition of the image, the information of interest and the composition of the image scene. Digital image processing undergoes three general steps:

- Pre-processing: passes through atmospheric, radiometric and geometric (rectification) corrections.

- Enhancement: consists of two techniques (spectral and multi-spectral).

- Information extraction: is the last step towards the final output of the image analysis and is represented by unsupervised and supervised image classification.

\subsection{Geographic Information Systems (GIS) Applications}

Through the present work the ARC GIS Software Version 9.2 was applied to create the different GIS maps. The Spot 4 images, the meteorological data, topographic maps, geological maps and field data were used to create the different thematic for desertification sensitivity through the GIS applications. These maps include:

Base map

A number of 17 topographic maps of scale 1:100,000 and the subset of Spot 4 image of the study area were used to create a base map including

Egyptian J. Desert Res., 59, 1-96 (2009) 
the different features through creating GIS layers for these features (cities, roads, urban areas, touristic areas and shore line). Fig. (17) shows the base map of the study area.

\section{Digital Elevation Model (DEM)}

The existing Digital Elevation Model (DEM) of 30m high resolution was used to show the different landforms along the study area, Fig. (18). Moreover, the following thematic maps of the (NWCZ) were detected:

- Climate Quality Index Map (CQI)

- Runoff Quality Index Map (RQI)

- Ground water Quality Index MAP (GQI),

- Soil taxonomy Map,

- Soil Quality Index Map (SQI),

- Erosion Quality Index MAP (EQI),

- Vegetation Quality Index MAP(VQI),

- Environmentally Sensitive Areas (ESAs) to Desertification Map.

\section{3- QUALITY MEASUREMENT OF THE ENVIRONMENTALLY SENSITIVE AREAS TO DESERTIFICATION}

The environmentally sensitive areas to desertification of the NWCZ, were detected using the arithmetic model adopted by Kosmas et al. (1999), (Figure 19) taking into account the local circumstances that identify the applied quality indices. In this accord, seven indices were used to assess desertification sensitivity index (DSI) and mapping the environmentally sensitive areas (ESAs) at the NWCZ. These indices are:

- Climate Quality Index (CQI)

- Run-off Quality Index (RQI)

- Groundwater Quality Index (GQI)

- Soil Quality Index (SQI)

- Erosion Quality Index (EQI)

- Vegetation Quality Index (VQI)

- Management Quality Index (MQI)

From the assessment results of each previous quality, one can get the value of Desertification Sensitivity Index (DSI) and classify the study zone into areas having different degrees of the sensitivity through application of the following equation:

$$
\mathrm{DSI}=(\mathrm{CQI} * \mathrm{RQI} * \mathrm{GQI} * \mathrm{SQI} * \mathrm{EQI} * \mathrm{VQI} * \mathrm{MQI})^{1 / 7}
$$

The following is the conceptual model of the NWCZ indices, (Figure 20) which is compiled by the Desert Research Center team work after Kosmas et al. (1999).

The qualities under consideration are calculated providing a measure of the inherent quality of the physical environment and the man-induced stress of desertification as follows: 


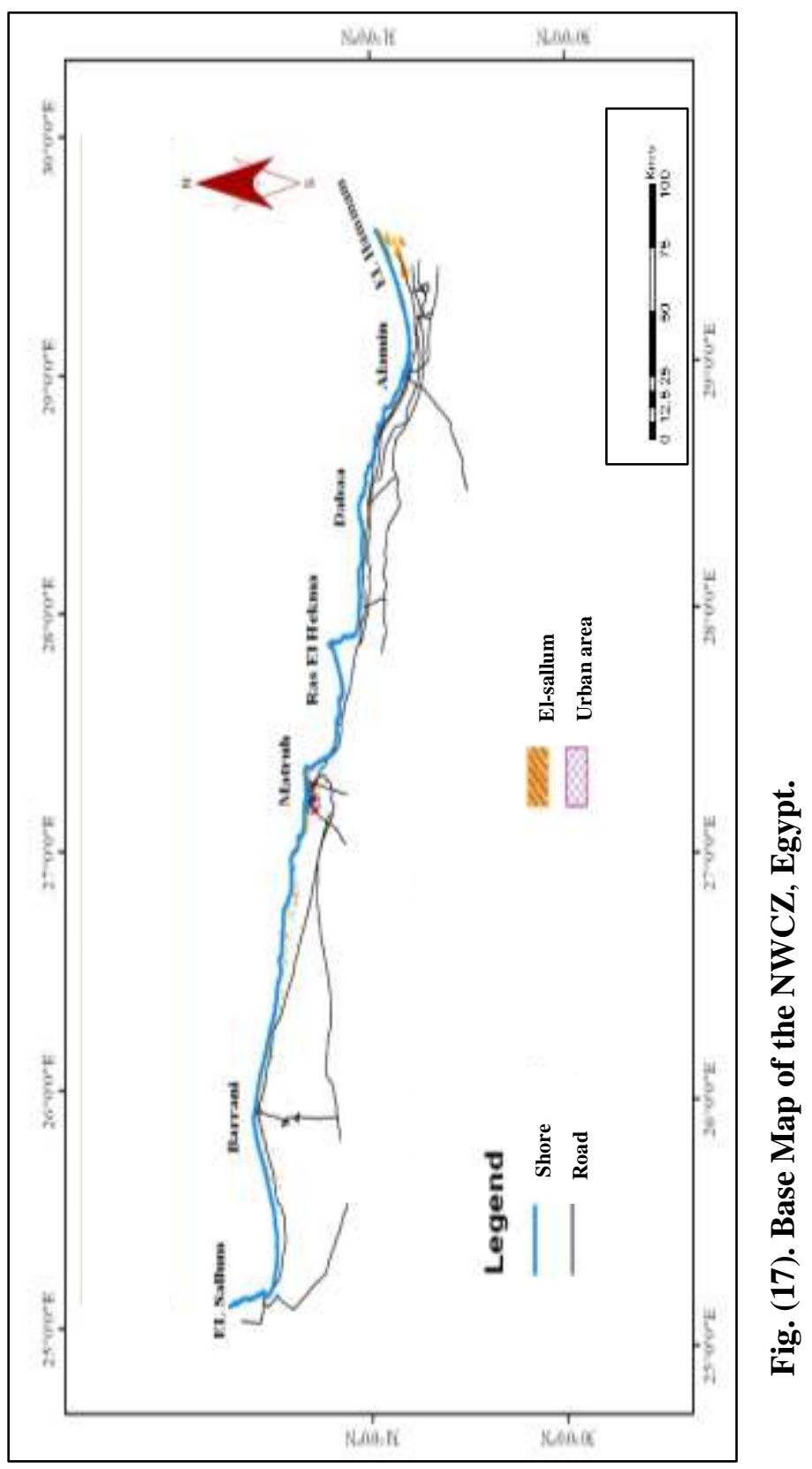

Egyptian J. Desert Res., 59, 1-96 (2009) 


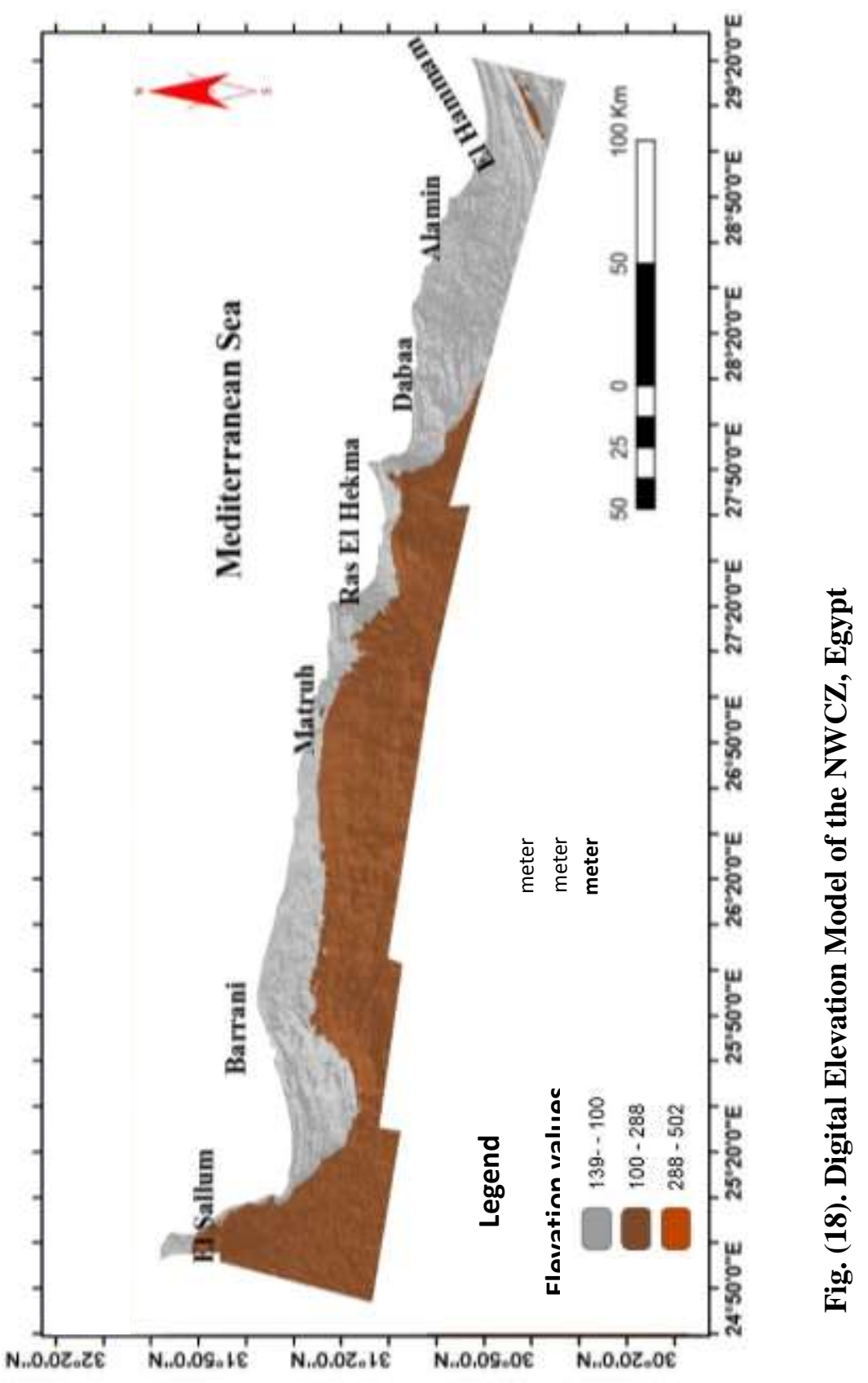

Egyptian J. Desert Res., 59, 1-96 (2009) 


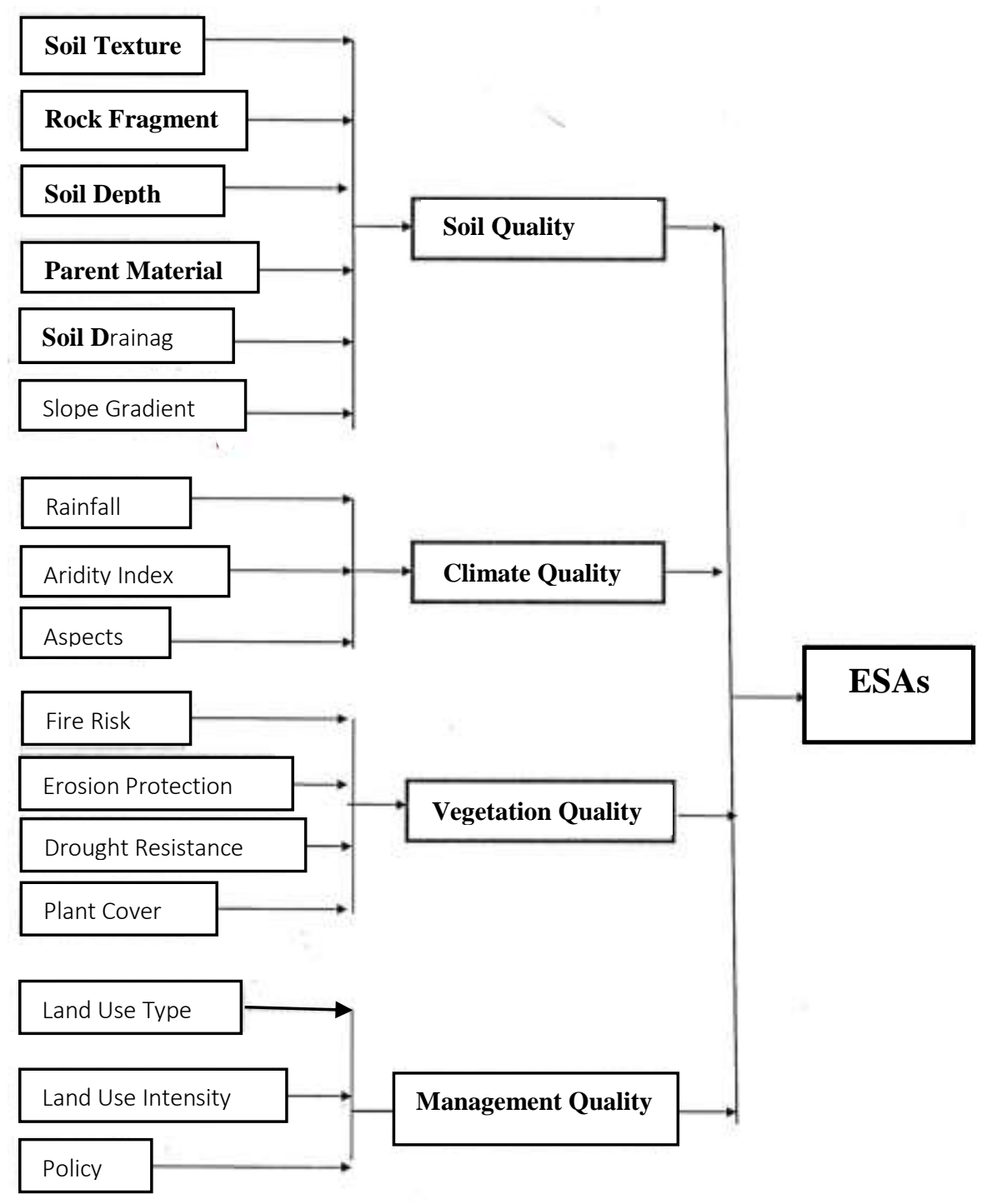

Fig. (19). The conceptual model of calculating indices after Kosmas et al. (1999).

Egyptian J. Desert Res., 59, 1-96 (2009) 


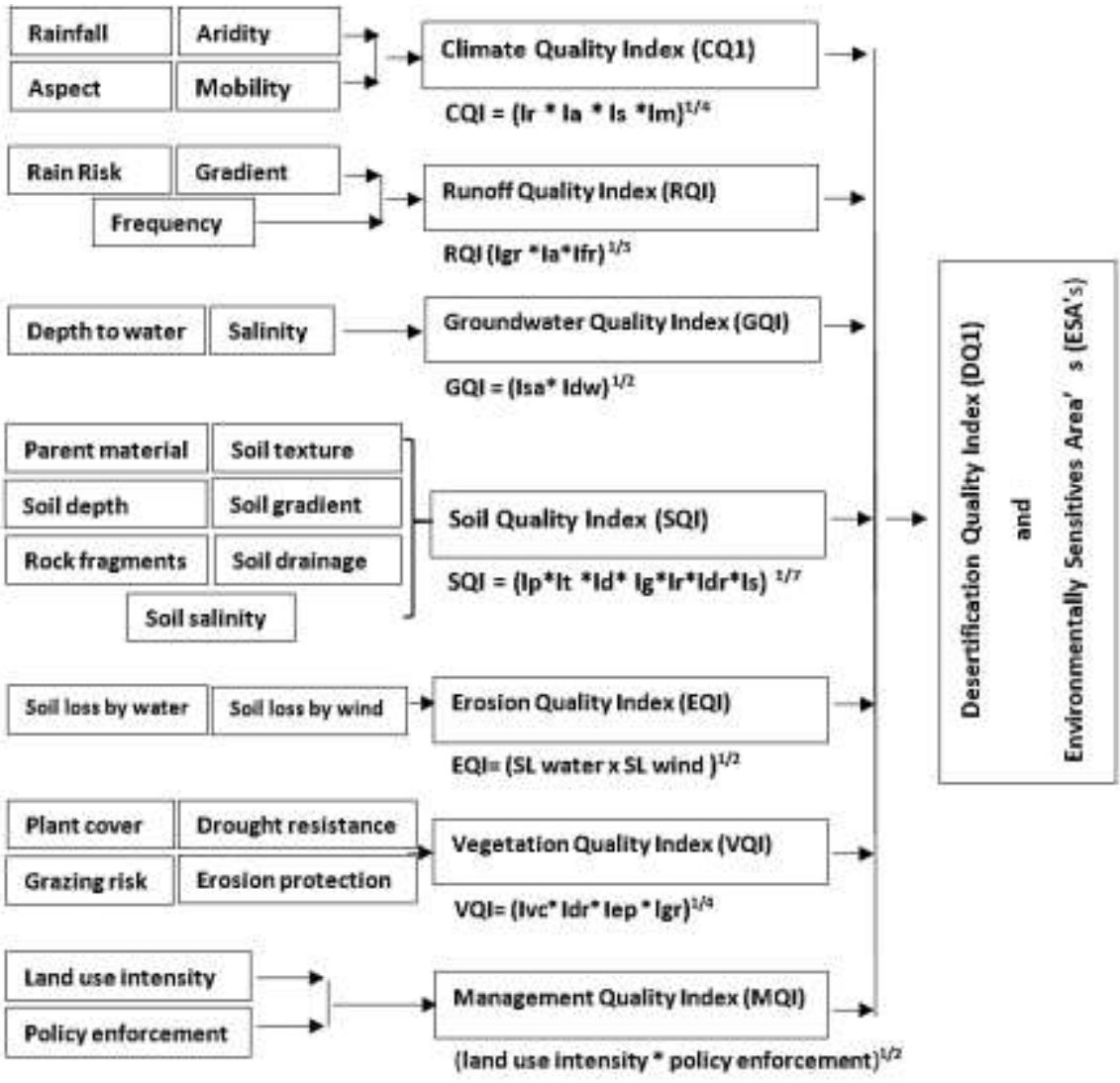

Fig. (20). The conceptual model of calculating indices of the NWCZ, Egypt.

\subsection{Climate Quality Index (CQI)}

The climate Quality Index was calculated using the following items:

i) Rainfall index(Ir),

ii) Aridity index(Ia),

iii) Aspect index(Is),

iv) Mobility index(Im).

$$
\mathrm{CQI}=\left((\mathrm{Ir})^{*}(\mathrm{Ia})^{*}(\mathrm{Is})^{*}(\mathrm{Im})\right)^{1 / 4}
$$




\subsubsection{Rainfall index (Ir)}

The rainfall index is divided into three classes (Kosmos et-al, 1999) as shown in the table (9).

The average annual Rainfall $(\mathrm{mm})$ was calculated for every 25 years from the collected climatic data as shown in table (10). From the data that are shown this table, it was noticed that the average annual rainfall equal to145.5 mm/year, which means that this region belongs to class (3) and the rainfall index equal (4) as sensitivity index to desertification.

\subsubsection{Aridity Index (Ia)}

The aridity index was calculated based on the United Nations Environment Program (UNEP, 1992). This equation was based on the average annual precipitation and potential evapotranspiration

Where:

$$
\mathrm{Ia}=(P / P E T)
$$

$\mathrm{P} \quad$ is the average annual precipitation $(\mathrm{mm})$

PET is the potential evapotranspiration $(\mathrm{mm})$

The climate was classified according to UNEP as shown in table (11), while the results of the study area are shown in table (12).

In conclusion, the calculated values of the aridity Index in the North Western Coastal zone using the UNEP equation (1992) indicate that The North Western Coastal zone lies in one category of aridity, namely arid.

\subsubsection{Aspect index (Is)}

Aspect index means the effect of winds on plant growth or surface erosion. In the NWCZ, the wind blows in winter and spring from N. and NW to SE. According to Kosmas et al. (1999) wind aspect is measured from the collected climatic data and they concluded that the winds blowing from SWSE are hot winds and have the high rate of evaporation and, in turn, soil dryness which leads to its deterioration. The opposite is true when the wind direction is NW-NE. In this context, the NW-NE winds take the value (1) as sensitivity index to desertification, meanwhile, the SW-SE winds take the value (2). The study revealed that at the NWCZ, the wind aspect is NW, therefore it takes the value (1) as sensitivity index to desertification.

Table (9). Annual precipitation, its classes and indices.

\begin{tabular}{|c|c|c|}
\hline Class & $\begin{array}{c}\text { Average Annual } \\
\text { Rainfall(mm) }\end{array}$ & Index \\
\hline 1 & $>650$ & 1.0 \\
\hline 2 & $280-650$ & 2 \\
\hline 3 & $<280$ & 4 \\
\hline
\end{tabular}


Table (10). Average annual rainfall (mm) at the NWCZ, Egypt.

\begin{tabular}{|c|c|c|c|c|c|}
\hline Station & $\mathbf{1 9 0 0 - 1 9 2 5}$ & $\mathbf{1 9 2 6 - 1 9 5 0}$ & $\mathbf{1 9 5 1 - 1 9 7 5}$ & $\mathbf{1 9 7 6 - 2 0 0 0}$ & Average \\
\hline El-Dabaa & 121.7 & 132.8 & 117.7 & 265.6 & 159.4 \\
Matruh & 169.7 & 156.5 & 130.8 & 147.3 & 151.1 \\
Barrani & 173.4 & 146.7 & 155.0 & 191.5 & 166.7 \\
El-Sallum & 104.9 & 115.2 & 95.4 & 103.7 & 104.8 \\
\hline \multicolumn{5}{|c|}{ Mean average } & 145.5 \\
\hline
\end{tabular}

Table (11). Climatic classification according to UNEP (1992).

\begin{tabular}{|c|c|c|}
\hline Classification & Aridity Index & Global land area \\
\hline Hyper- arid & AI $<\mathbf{0 . 0 5}$ & $7.5 \%$ \\
\hline Arid & $0.05<$ AI $<\mathbf{0 . 2 0}$ & $12.1 \%$ \\
\hline Semi-arid & $\mathbf{0 . 2 0}<$ AI $<\mathbf{0 . 5 0}$ & $\mathbf{1 7 . 7 \%}$ \\
\hline Dry sub humid & $\mathbf{0 . 5 0}<$ AI $<\mathbf{0 . 6 5}$ & $\mathbf{9 . 9 \%}$ \\
\hline
\end{tabular}

Table (12). The calculated aridity index at the NWCZ, Egypt.

\begin{tabular}{|c|c|}
\hline Location & Aridity index \\
\hline El- Dabaa & 0.066 \\
\hline Matruh & 0.175 \\
\hline Barrani & 0.089 \\
\hline El-Sallum & 0.112 \\
\hline
\end{tabular}

\subsubsection{Mobility Index (Im)}

\section{Aeolian sand deposits}

Aeolian sand deposits represent one of the environmental conditions that hinder the development operations in the new reclaimed areas.

Aeolian deposits in the NWCZ represent the main land features and the mobile sand dunes and shifting sand are the major constrains for the socio-economic development activities in this area. These activities include land reclamation, new settlements as well as high ways. 
Annual rates and direction of aeolian deposits movement using drift potential (DP), mobility index (Im) and aeolian sand deposits index could be calculated as follows:

The direction and relative amount of sand migration (sand drift) were calculated using the equations given by Fryberger (1979)

Where

$$
\mathrm{Q}=\mathrm{v}^{2}\left(\mathrm{v}-\mathrm{v}_{\mathrm{t}}\right) \mathrm{t}
$$

$\mathrm{Q}=$ proportional amount of sand $\operatorname{drift}(\mathrm{VU})$.

$\mathrm{v}=$ average wind velocity $(\mathrm{m} / \mathrm{s})$.

$\mathrm{v}_{\mathrm{t}}=$ impact threshold velocity $(\mathrm{m} / \mathrm{s})$.

$\mathrm{t}=$ time of wind blowing (frequency percentage of wind \%).

The values derived from this equation refer to:

a- Drift potential (DP) refer to the relative amount of sand drift potential at station for a period of time and it is numerically expressed in vector units (VU).

b- Resultant drifts potential (RDP) and Resultant Drift Direction (RDD) refer to the magnitude and direction of the vector resultants of drift potentials from the 12 compass directions.

Fryberger (1979) classified the energy of surface winds in arid regions into three classes based on the average annual drift potential:

Low-energy wind environment $\quad$ DP $<200 \mathrm{VU}$

Intermediate-energy wind environment DP 200-399 VU

High-energy wind environment $\quad$ DP $>400 \mathrm{VU}$

In the present work, the sand drifts potential formula of Fryberger, 1979 , is used by applying the average effective-wind speed. These measurements were taken at Dabaa, Matrouh, Barrani and El-Sallum meteorological stations (1968-2009). Weighting factor is the term used to represent the values of the relative rates of winds of different average velocities, which can move sand. The weighting factors are calculated by substituting the wind velocity values (average of wind speed velocity) by the weighting formula.

The calculated weighting factors for the relative rate of transported sand are given in table (13). These values can be divided by 100 to reduce the weighting factor size for convenience in plotting of sand roses, representing the potential sand drift from the 12 directions of the compass. The lengths of sand rose arms are proportional to the sand drift potential from a given direction as computed in vector units). These sand roses represent the annual data at each station (Figures 21-24). 
Table (13). Determination of weighting factors for relative rate of sand transport.

\begin{tabular}{|c|c|c|c|c|}
\hline $\begin{array}{c}\text { Velocity } \\
\text { category } \\
\text { (knots) }\end{array}$ & $\begin{array}{c}\text { Mean velocity of } \\
\text { the wind(knots) } \\
(\mathbf{v})\end{array}$ & $\mathbf{v}^{\mathbf{2}}$ & $(\mathbf{v}-\mathbf{v t})$ & $\begin{array}{c}\text { Weighting Factor } \\
\mathbf{2}(\mathbf{v}-\mathbf{v} \mathbf{t}) / \mathbf{1 0 0}\end{array}$ \\
\hline $7-10$ & 8.5 & 72.25 & 0.7 & 0.5 \\
\hline$>10-16$ & 13.5 & 82.25 & 5.7 & 10.4 \\
\hline$>16-21$ & 19 & 361.0 & 11.2 & 40.4 \\
\hline$>21-27$ & 24.5 & 600.25 & 16.7 & 100.2 \\
\hline$>27-33$ & 30.5 & 930.25 & 22.7 & 211.2 \\
\hline
\end{tabular}

$V_{t}=7.8$ knots

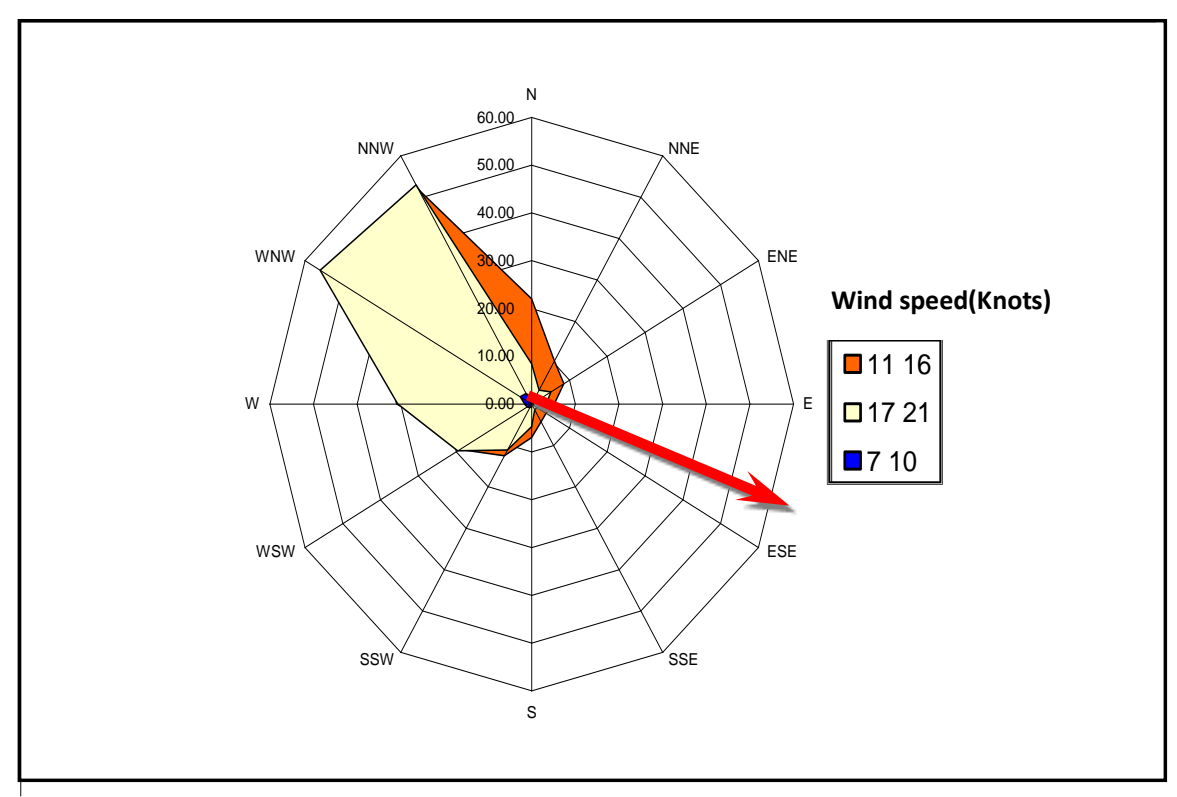

Fig. (21). Annual sand rose of El Dabaa station at the NWCZ, Egypt. 


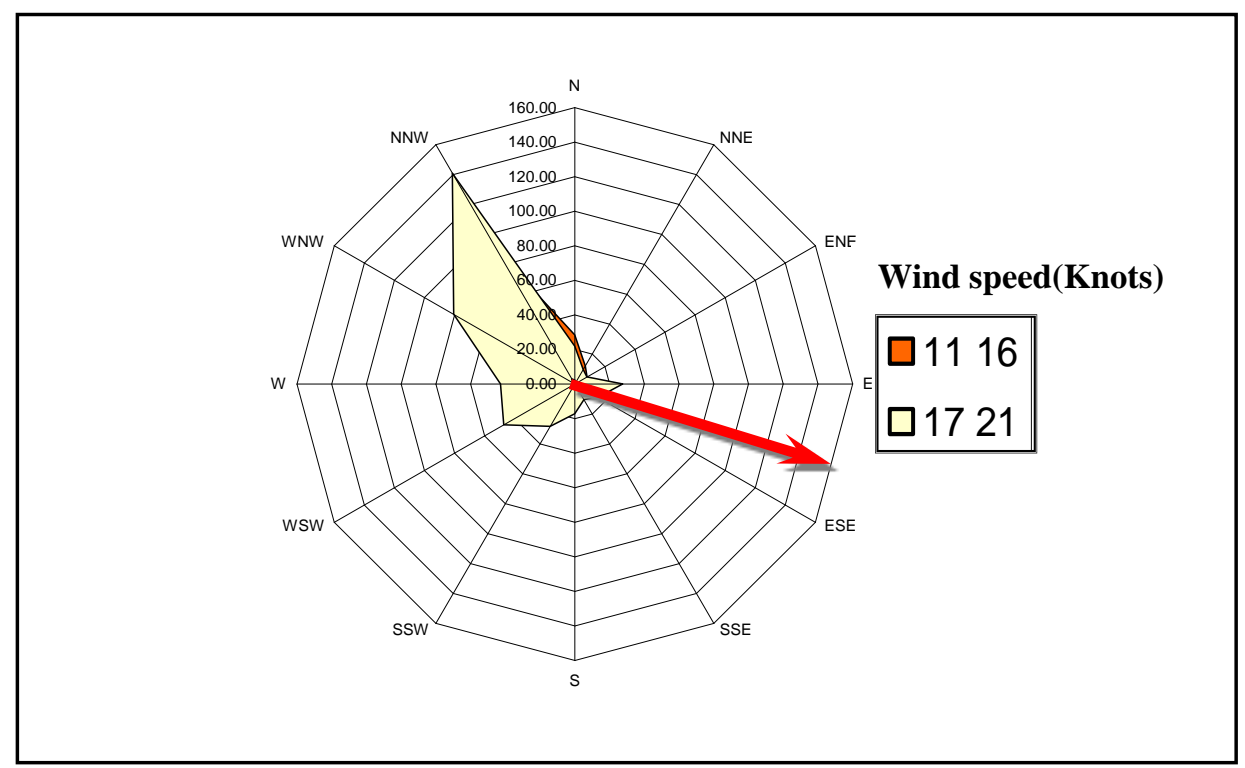

Fig. (22). Annual sand rose of Matruh station at the NWCZ, Egypt

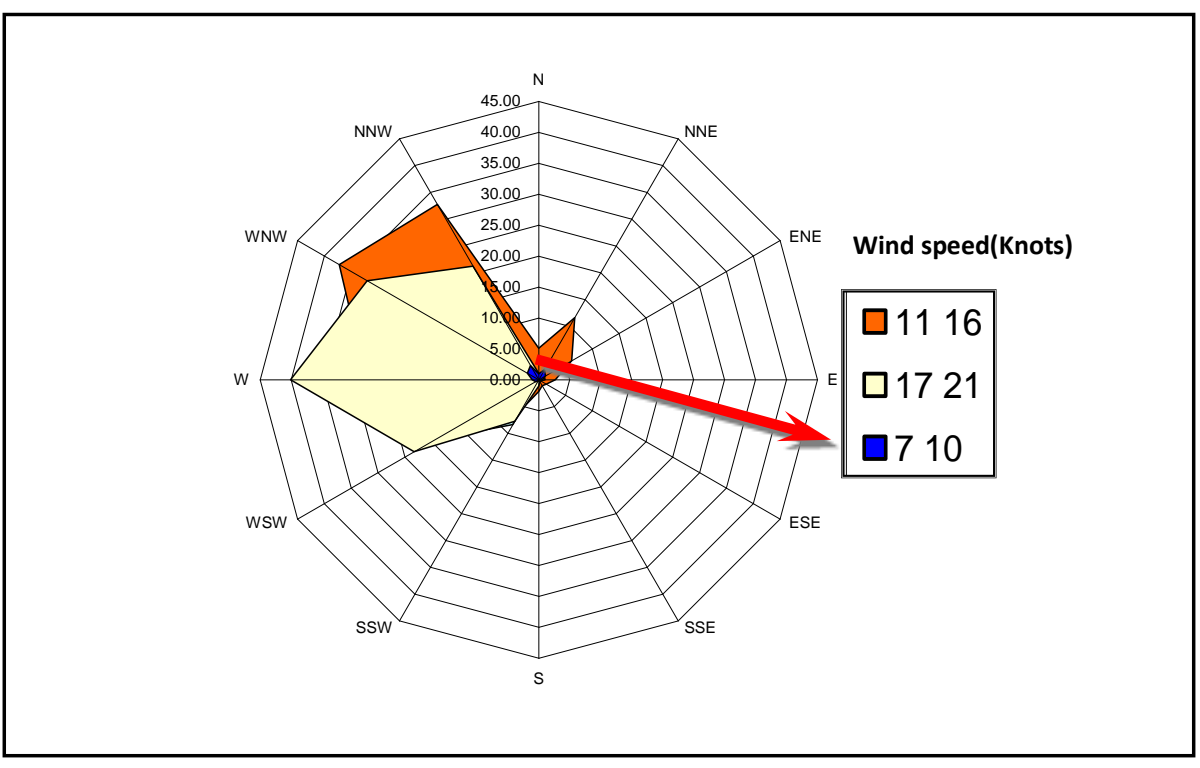

Fig. (23). Annual sand rose of Barrani station at the NWCZ, Egypt.

Egyptian J. Desert Res., 59, 1-96 (2009) 


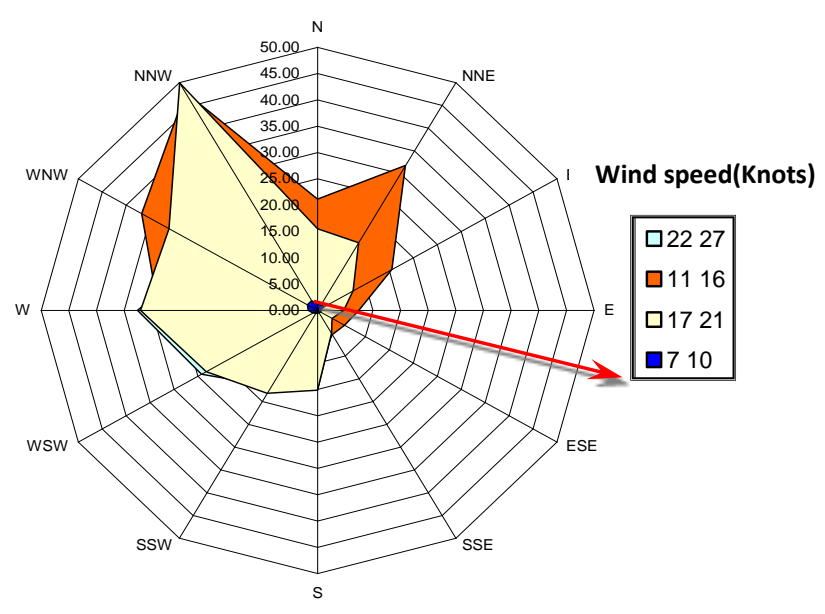

Fig. (24). Annual sand rose of El-Sallum station at the NWCZ, Egypt.

Based on the results obtained in table (14), we find that the study area has intermediate-energy wind environment based on the classification of Fryberger (1979), and the movement of aeolian deposits is dominantly from north-northwest to south - southeast.

Table (14). Sand drifts potential and its direction at the NWCZ, Egypt.

\begin{tabular}{|c|c|c|c|}
\hline Location & $\begin{array}{c}\text { Resultant Drift } \\
\text { potential RDP } \\
(\text { VU) }\end{array}$ & $\begin{array}{c}\text { Annual movement of } \\
\text { sand quantity }\left(\mathrm{m}^{3} / \mathrm{km}\right)\end{array}$ & $\begin{array}{c}\text { Movement } \\
\text { direction }\left(^{\circ}\right)\end{array}$ \\
\hline El Dabaa & 389.57 & 27269.9 & 296.0 \\
\hline Matrouh & 472.10 & 33047.0 & 297.4 \\
\hline Barrani & 271.24 & 18986.8 & 286.1 \\
\hline El Sallum & 284.43 & 19910.0 & 288.2 \\
\hline
\end{tabular}

Mobility index (Im)

A dune mobility index, Im, which can be related to wind energy $(\mathrm{m} / \mathrm{s})$ and effective precipitation $(\mathrm{mm})$, can be calculated as following (Pye and Tsoar, 1990):

$$
\operatorname{Im}=w /(P / P E T)
$$

Where $\mathrm{w}$ is the percentage of the time wind is blowing above the threshold for sand transport (taken to be $4.0 \mathrm{~m} / \mathrm{s}$ ), $\mathrm{P}$ is the annual rainfall $(\mathrm{mm})$, and PET is the annual potential evapotranspiration $(\mathrm{mm})$. 
Critical values of Im have been identified for different degrees of dune activity (Table 15).

Table (15). Critical values of Im.

\begin{tabular}{|l|c|c|}
\hline Description & Mobility quality & Mobility Index \\
\hline Non active & $<50$ & 1.0 \\
\hline Medium active & $50-100$ & 1.3 \\
\hline Active & $100-200$ & 1.6 \\
\hline Very active & $>200$ & 2.0 \\
\hline
\end{tabular}

Through previous relationship the mobility index (Im) was calculated to areas of El Dabaa, Matruh, Barrani and El-Sallum (Table 16).

Based on the previous classifications and the obtained results, the northwestern coastal zone has highly active dune.

Table (16). Mobility index of the NWCZ, Egypt.

\begin{tabular}{|c|c|c|c|c|}
\hline Location & $\begin{array}{c}\text { Aridity } \\
\text { index }\end{array}$ & $\begin{array}{c}\text { Effective wind } \\
\text { \% }\end{array}$ & $\begin{array}{c}\text { Mobility } \\
\text { Quality }\end{array}$ & $\begin{array}{c}\text { Mobility } \\
\text { Index }\end{array}$ \\
\hline El- Dabaa & 0.066 & 56.2 & 851.5 & 2 \\
\hline Matruh & 0.175 & 66.0 & 377.1 & 2 \\
\hline Barrani & 0.089 & 41.9 & 470.8 & 2 \\
\hline El-Sallum & 0.112 & 58.2 & 529.1 & 2 \\
\hline
\end{tabular}

The data obtained show that Sisi-Barrani and El-Sallum areas are the most areas hazardously affected by the aeolian sand encroachment, as they lay under the influence of Quaternary sediments which are characterized by fragile and intensive human use especially in rain fed areas. These activities make them move under the influence of wind from the northern and western directions. These conditions require establishing green belts and windbreaks to protect the infrastructure and population activities from sand encroachment.

\subsubsection{Calculation of the climate quality index (CQI)}

To determine the value of climate quality index, the values of climate elements were applied in the arithmetic model as follows and the climate quality index is shown in table (17).

$$
\mathrm{CQI}=(\text { Rainfall index } * \text { Aridity index } * \text { Aspect index } * \text { Mobility index })^{1 / 4}
$$

The obtained values of CQI $(0.852-1.088)$ belong to class (1) that means the climatic quality in the NWCZ has high quality as illustrated in table (18). 
Table (17). Climate quality index at the NWCZ, Egypt.

\begin{tabular}{|c|c|c|c|c|c|}
\hline Location & $\begin{array}{c}\text { Rainfall } \\
\text { index }\end{array}$ & $\begin{array}{c}\text { Aridity } \\
\text { index }\end{array}$ & $\begin{array}{c}\text { Aspect } \\
\text { index }\end{array}$ & $\begin{array}{c}\text { Mobility } \\
\text { Index }\end{array}$ & CQI \\
\hline El- Dabaa & 4 & 0.066 & 1 & 2 & 0.852 \\
\hline Matruh & 4 & 0.175 & 1 & 2 & 1.088 \\
\hline Barrani & 4 & 0.089 & 1 & 2 & 0.919 \\
\hline El-Sallum & 4 & 0.112 & 1 & 2 & 0.973 \\
\hline
\end{tabular}

Table (18). Corresponding index to climate.

\begin{tabular}{|c|c|c|}
\hline Class & Description & Range \\
\hline 1 & High quality & $<1.15$ \\
\hline 2 & Moderate & $1.15-1.81$ \\
\hline 3 & Low & $>1.81$ \\
\hline
\end{tabular}

\subsection{Runoff Quality Index (RQI)}

The runoff is created from the quantity of rainfall reaching $>10 \mathrm{~mm}$ /days. In the area, in question (NWCZ) the main aerial resources are runoff, so it is relevant to add RQI to the indices group mentioned in the Kosmas et al. model (1999). The study of RQI revealed that the runoff phenomenon affects through a number of factors; rain risk, frequency and gradient, (Tables 19-21).

Table (19). Rain Risk Index (Ir).

\begin{tabular}{|c|c|c|c|}
\hline Class & Description & $\begin{array}{c}\text { Annual maximum daily } \\
\text { rainfall (mm/day) }\end{array}$ & Index \\
\hline 1 & Low & $<10$ & 1.0 \\
\hline 2 & Moderate & $10-20$ & 1.7 \\
\hline 3 & High & $>20$ & 2.0 \\
\hline
\end{tabular}

Table (20). Rain Frequency Index (Ifr).

\begin{tabular}{|c|c|c|c|}
\hline Class & Description & Range of rainy storm & Index \\
\hline 1 & Low & $<2$ & 1.2 \\
\hline 2 & Moderate & $2-5$ & 1.7 \\
\hline 3 & High & $>5$ & 2.0 \\
\hline
\end{tabular}

Table (21). Gradient (basin slope) Index (Igr).

\begin{tabular}{|c|c|c|c|}
\hline Class & Description & Basin slope (\%) & Index \\
\hline 1 & Low & Flat to slight $(<2)$ & 1.0 \\
\hline 2 & Moderate & Sloping $(2-5)$ & 1.6 \\
\hline 3 & High & Steep $(>5)$ & 2.0 \\
\hline
\end{tabular}



equation:

The RQI evaluation was conducted by calculating it by the following

$\mathrm{RQI}=(\text { Rain risk index } * \text { Rain frequency index } * \text { Gradient index })^{1 / 3}$

To identify the type of (RQI), table (22) shows the classes and their indices range.

Table (22). Runoff Quality Index.

\begin{tabular}{|c|c|c|}
\hline Class & Description & Range \\
\hline 1 & High quality & $<1.23$ \\
\hline 2 & Moderate quality & $1.23-1.67$ \\
\hline 3 & Low quality & $>1.67$ \\
\hline
\end{tabular}

As to the results of RQI at the NWCZ, it could be summed up from the obtained results in table (23) and figure (25).

Table (23). Runoff Quality Index values at the NCWZ, Egypt.

\begin{tabular}{|c|c|c|c|c|c|}
\hline \multirow{2}{*}{ Region } & \multicolumn{3}{|c|}{ Runoff Indices } & \multicolumn{2}{c|}{ Runoff Quality } \\
\cline { 2 - 6 } & Rain risk & Frequency & Gradient & RQI & description \\
\hline Dabaa- Matruh & 2.0 & 1.7 & 1.6 & 1.75 & Low \\
\hline Matruh - Barrani & 1.7 & 1.7 & 1.6 & 1.66 & Moderate \\
\hline Barrani-El-Sallum & 1.7 & 1.2 & 1.6 & 1.48 & Moderate \\
\hline
\end{tabular}

\subsection{Groundwater Quality Index (GQI)}

Groundwater is considered the second source of water at the NWCZ. The previous studies on the groundwater resources revealed that the water salinity might lead to deterioration of the soils. In addition, water depth at some localities was found at very deep depth.

Based on the above two important factors, it is necessary to add GQI among the system of (ESAs). Data in tables (24 and 25) show the classes of salinity Levels and water depth.

The groundwater index at NWCZ is calculated and evaluated in some localities according to the suggested arithmetic equation as follows:

$\mathrm{GQI}=(\text { Water Salinity Index } * \text { Water Depth Index })^{1 / 2}$

From the data in tables $(24,25)$, it could be stated that the salinity values ranged from 5000 to $10000 \mu \mathrm{Scm}^{-1}$ and the surface water depth varied from 25-50 m depth. The GQI results of the selected sites at the NCWZ are presented in table (26) and fig. (26). 


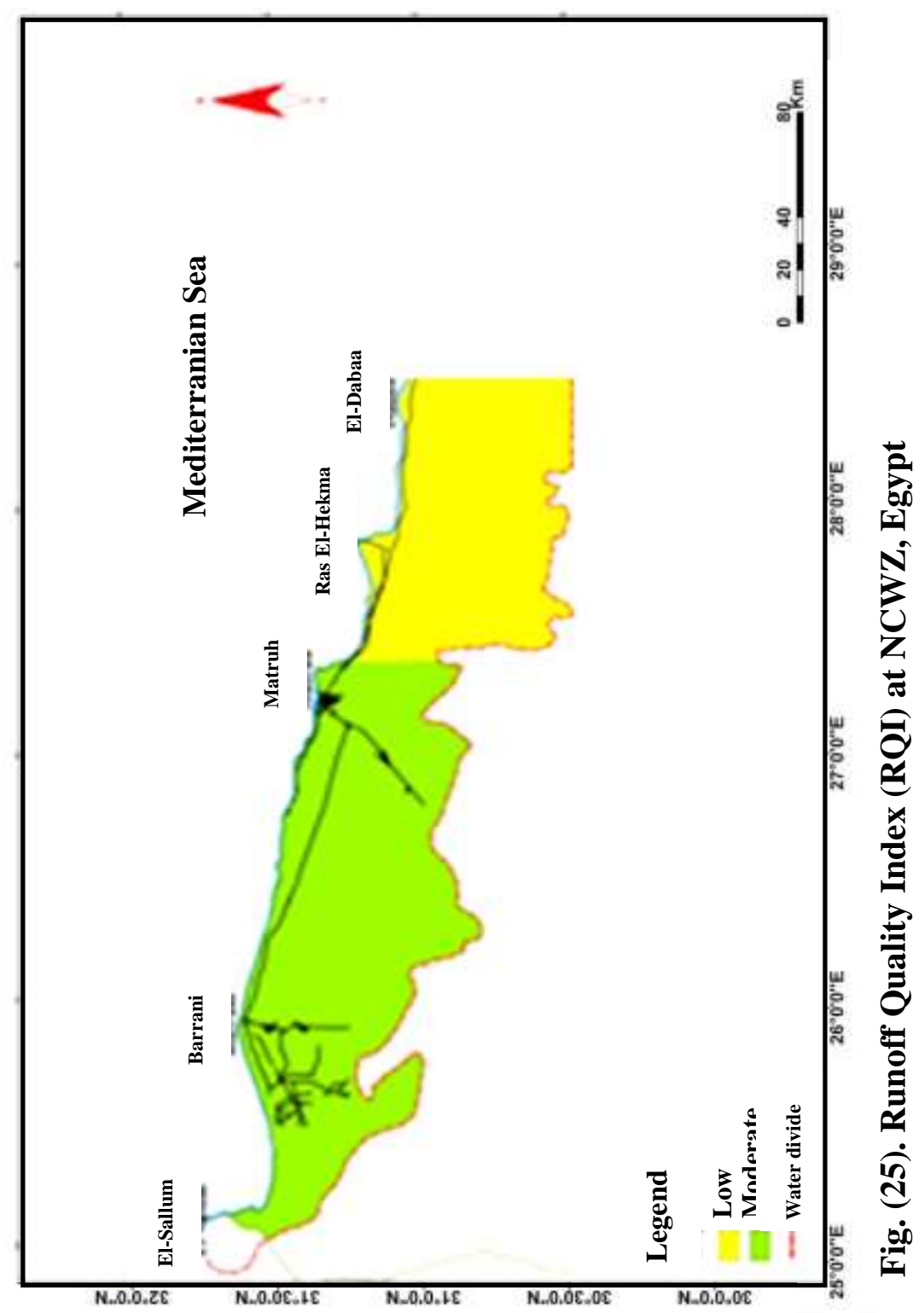

Egyptian J. Desert Res., 59, 1-96 (2009) 
Table (24). Groundwater salinity and the corresponding index.

\begin{tabular}{|c|c|c|c|}
\hline Class & Description & Salinity (ppm) & Index \\
\hline 1 & Low & $<5000$ & 1.0 \\
\hline 2 & Moderate & $5000-10000$ & 1.5 \\
\hline 3 & High & $>10000$ & 2.0 \\
\hline
\end{tabular}

Table (25). Water depth and the corresponding index.

\begin{tabular}{|c|c|c|c|}
\hline Class & Description & Water depth (m) & Index \\
\hline 1 & Shallow & $<25$ & 1.0 \\
\hline 2 & Moderate & $25-50$ & 1.6 \\
\hline 3 & Deep & $>50$ & 2.0 \\
\hline
\end{tabular}

Table (26). Groundwater salinity and depth indices the corresponding groundwater quality index at the NWCZ, Egypt.

\begin{tabular}{|c|c|c|c|c|}
\hline \multirow{2}{*}{ Region } & \multicolumn{2}{|c|}{ Index Values } & \multicolumn{2}{c|}{ GQI } \\
\cline { 2 - 5 } & Water Salinity & Water depth & values & Description \\
\hline Dabaa -Matruh & 1.5 & 1.0 & 1.22 & Moderate \\
\hline Matruh-Barrani & 1.5 & 1.0 & 1.22 & Moderate \\
\hline Barrani-El-Sallum & 2.0 & 1.6 & 1.79 & Low \\
\hline
\end{tabular}

\subsection{Soil Quality Index (SQI)}

\subsubsection{Soil Characteristics and Classification}

In the current work, soil attributes (parent material, soil texture, effective soil depth, slope gradient, rock fragments on the surface, soil drainage and soil salinity) as well as the taxonomic units on the level of subgroup were characterized depending on the pertinent soil studies achieved by Hammad (1968), El-Shazly (1978) and Ahmed (1983).

The soil taxonomic units, their areas and the associated landforms at the NWCZ are given in table (27) and figure (27). 


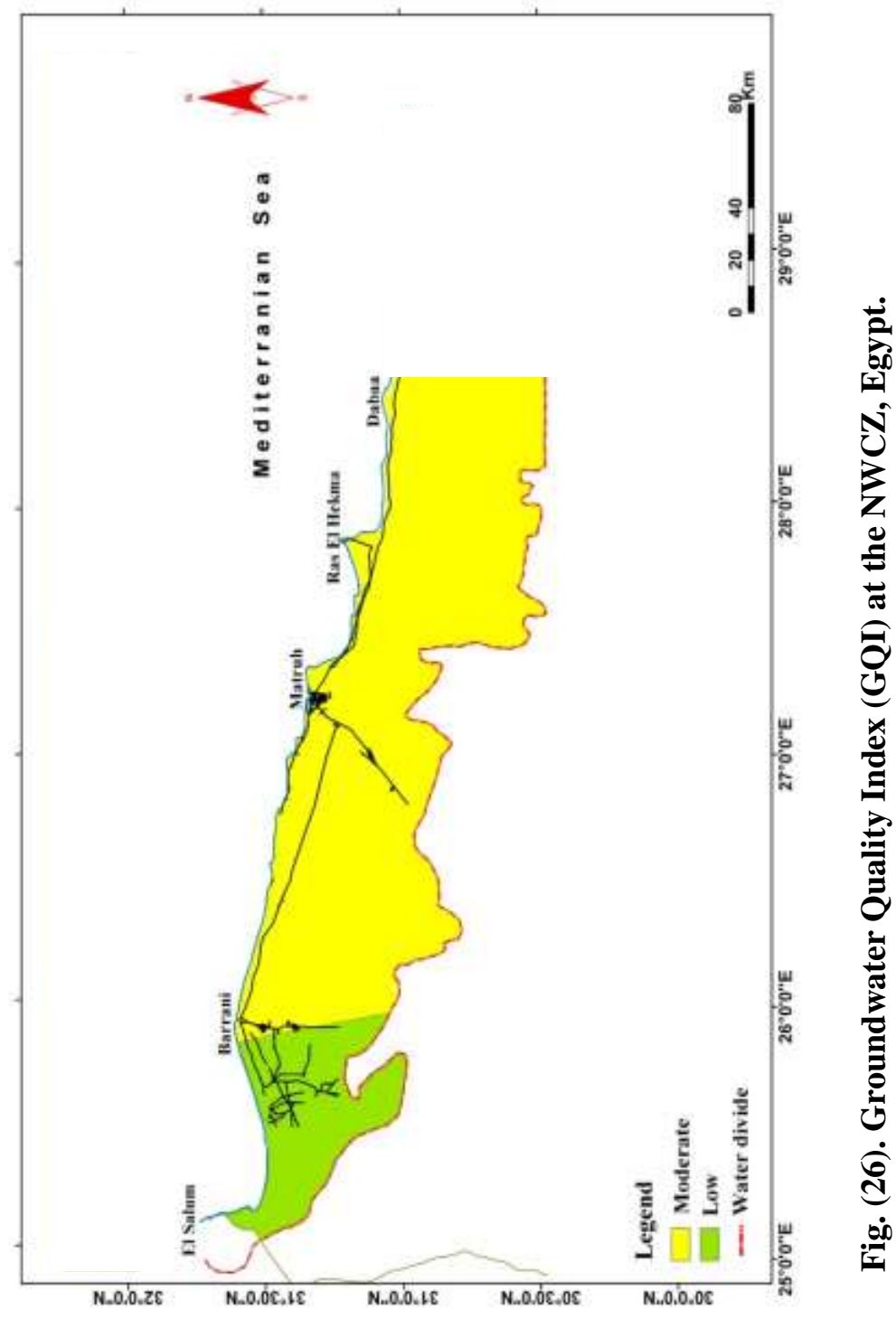

Egyptian J. Desert Res., 59, 1-96 (2009) 
Table (27). Soil taxonomic units, their areas and the associated Landforms at the NWCZ, Egypt.

\begin{tabular}{|c|c|c|c|}
\hline Landforms & Soil taxonomic units & $\begin{array}{c}\text { Area } \\
\text { (thousand } \\
\text { feddan) }\end{array}$ & $\%$ \\
\hline $\begin{array}{c}\text { Interdunal depression \& wadi } \\
\text { floor ended with soil fans }\end{array}$ & Typic Calcids & 785.5 & 32.73 \\
\hline Depositional plains & Lithic Torriorthents & 766 & 31.92 \\
\hline $\begin{array}{c}\text { Structural plateau } \\
\text { with undulating surface and } \\
\text { low slopes }\end{array}$ & Lithic Torripsamments & 229 & 9.54 \\
\hline Lagoonal depression & Gypsic Aquisalids & 26 & 1.08 \\
\hline Beach ridges & Oolitic Calcipsamments & 22 & 0.92 \\
\hline Tnland ridges and escarpments & Miscellaneous & 16.5 & 0.69 \\
\hline Total & & 2400 & 100 \\
\hline
\end{tabular}

From the table's data and map, it is obviously clear that the dominant taxonomic unit in the NWCZ is the Typic Calcids (about 785.5 thousand feddan), which represents $32.73 \%$ of the total area. It is characterized by an almost flat to slightly undulating to undulating topography with surface slope ranging from 0.2 to $2 \%$, soil drainage is good, its surface is covered by native vegetation of different types and densities beside some areas planted with fig and olive trees and/or cultivated with field crops (wheat and barley). Gravels and pebbles are also found in scattered patches on the surface with small quantities. The soils are deep $(>100 \mathrm{~cm})$, soil texture is sandy loam (SL) to sandy clay loam (SCL) with sub-angular blocky to blocky structure, soil reaction $(\mathrm{pH})$ is slightly to moderately alkaline (7.5-8) and soil salinity does not exceed $9.6 \mathrm{dSm}^{-1}$.

The soils are calcareous in nature where $\mathrm{CaCO}_{3}$ content reached $48.3 \%$ in the interdunal depressions and $57.6 \%$ in the wadi floor and fans. Organic matter content does not exceed $0.4 \%$ and sometimes gypsum is found in the eastern part of the area (El Gharbaniat), where it forms about $20.02 \%$ of the soil components in the interdunal depression. 


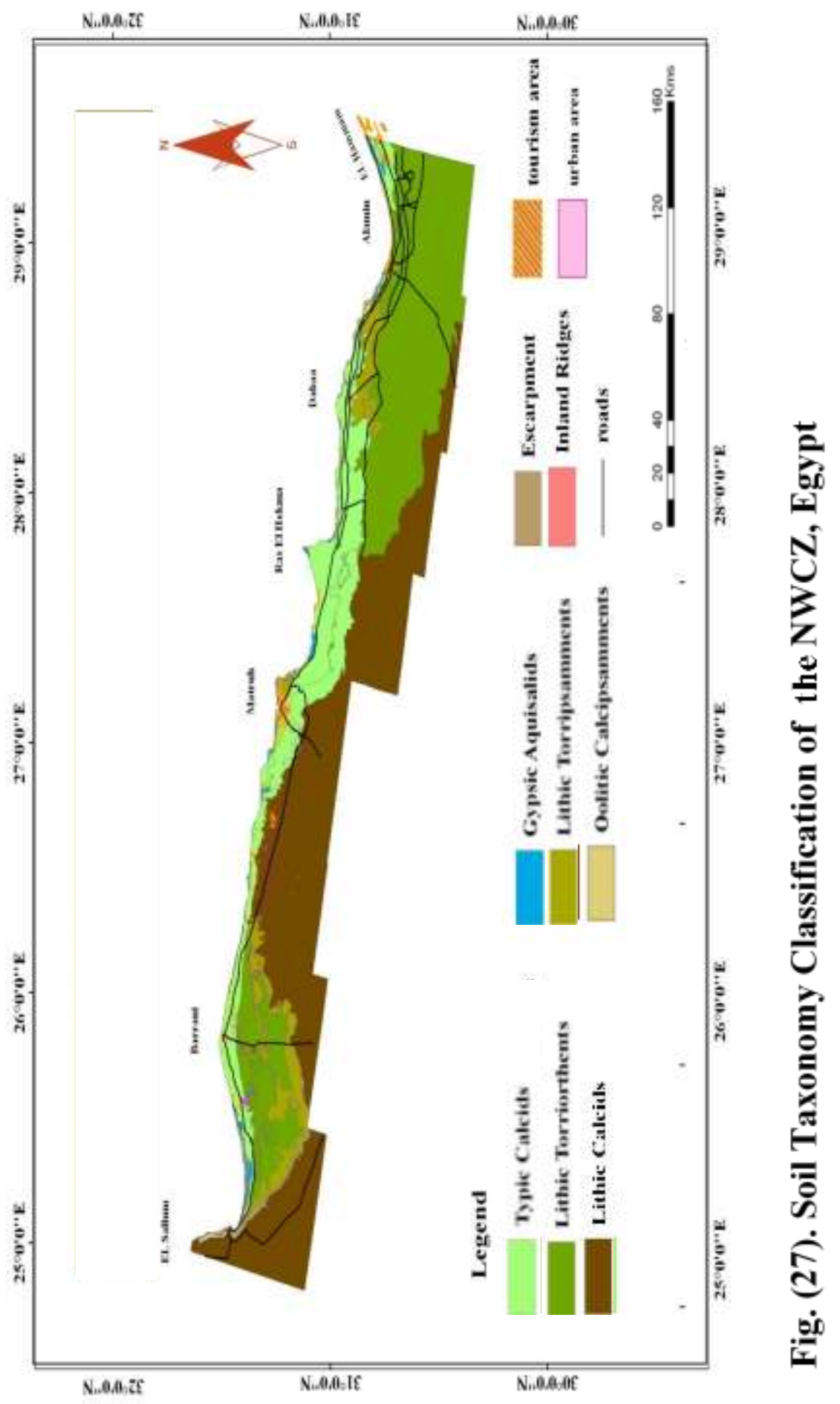

Egyptian J. Desert Res., 59, 1-96 (2009) 
Regarding the subgroup Lithic Torriorthents, it covers a significant area (about 766 thousand feddan), $31.92 \%$ of the total area. This soils subgroup is found in scattered sites south of the coastal plain with flat to slightly undulating topography and almost flat surface slope (1-2\%), the soil surface is covered with rock fragments of different sizes, and natural vegetation is also observed beside grown field crops (barley). The soils are shallow $(30-50 \mathrm{~cm})$, soil texture is gravelly SL to loamy sand (LS), slightly saline (3.4-4.2 $\left.\mathrm{dSm}^{-1}\right)$, lime content (37.6-48.3\%), organic matter content (0.18-0.38\%) and soil reaction is slightly to moderately alkaline (7.6-8.2).

Concerning the soils of the subgroup Lithic Calcids, these soils represent the structural plateau (about 555 thousand feddan), and cover $23.12 \%$ of the total area, they are characterized by rough and undulating topography with surface slope $(>15 \%)$. The soils are very shallow $(<30 \mathrm{~cm})$, so the soil drainage is very poor. The soil surface is covered with gravels and rock fragments with various sizes also with natural vegetation which exists in communities. Soil texture ranges from LS to SCL with massive to blocky structures. The soils contain lime (19.7-44.1\%), salts $\left(2.7-15 \mathrm{dSm}^{-1}\right)$, soil reaction is slightly to moderately alkaline (7.7-8.2) and organic matter $(<0.84 \%)$.

As to the soils of the subgroups Lithic Torripsamments, Gypsic Aquisalids and Oolitic Calcipsamments, they occupied small areas of about 229,26 and 22 thousand feddan that represents $9.4 \%, 1.08 \%$ and $0.92 \%$, of the total area, respectively.

The characteristics of these soil groups could be summed up in the following:

- Lithic Torripsamments: These soils are found in the extreme south of El Dabaa area where the sand sheets and g soils of quartzitic sand are dominant. The soils are shallow $(30-50 \mathrm{~cm})$ with almost flat topography in case of sandy sheets or undulating in the quartzitic sand with slopes depending on the type of surface topography. The soils surface is covered with gravels and stones of different sizes, also with some wild plants spots. They are of coarse - textured (sandy) with single grain structure, salt affected $\left(8-13.3 \mathrm{dSm}^{-1}\right)$, soil reaction (7.47.8), lime content (7.8-9.0\%) and very low organic matter $<0.1 \%$ of the soil components.

- Gypsic Aquisalids: This soils group is dominating along the coastal strip as sabkhas or salt marshes with flat topography and elevation less than or at the same level of the sea, the surface is covered with halophytes or with thick crust of salt origin and black organic matter. The soils suffer from water logging and consequently the soil depth differs between shallow and moderately deep (30-50 and/or 50-100), the soil texture is LS-SL with massive structure, lime content (< $34.9 \%$ ), soil reaction is slightly to moderately alkaline where $\mathrm{pH}$ values are ranging from 7.5-8.1, the soil is extremely saline where salt 
content is up to $103.2 \mathrm{dSm}^{-1}$ and gypsum content ranged from 8.9 to $25.5 \%$.

- Oolitic Calcipsamments: This soils group is hilly, stretching in narrow discontinuous strips parallel to the seacoast; its surface is covered with natural plants or fig trees. It is deep $(>100 \mathrm{~cm})$ with undulating surface topography and sloping gradient (5-10\%), nearly salt-free or slightly saline $\left(<4.7 \mathrm{dSm}^{-1}\right)$, contains very high lime content $(85-98 \%)$, soil reaction is slightly alkaline as $\mathrm{pH}$ values (7.4-7.8) and organic matter content is very low $(<0.3 \%)$.

- The inland ridges and the escarpments of the plateau have an area of about 16500 feddan which represents $0.6 \%$ of the total area of the NWCZ.

In light of the above mentioned, the main obstacles which impact negatively on the productivity of these soils and accelerate their deterioration could be summed up into the following:

- Rough topography: representing the soils associated with the coastal hills.

- Shallow soil profile: representing the soils of the sabkhas, sandy sheets, quartzitic sand of undulating surface and the dissected rocky surface of the plateau.

- Coarse - textured soils: representing the soils of the sandy sheets and the quartzitic sand of undulating surface.

- Poor soil drainage: representing the soils of the sabkhas, sandy sheets and dissected rocky surface of the plateau.

- Excess salt content: representing the soils of the sabkhas, sandy sheets, quartzitic sand of undulating surface and the dissected rocky surface of the plateau.

\subsubsection{Parameters used for assessment of soil quality}

Soil is a dominant factor of the terrestrial ecosystems especially in arid and semi-arid conditions, particularly through its effect on biomass production. Soil quality indicators for mapping of (ESAs) can be related to water availability and erosion resistance. This quality can be evaluated by using simple soil properties such as: parent material, soil depth, soil texture, slope gradient, rock fragments cover, soil drainage and soil salinity. The use of these properties for defining and mapping of ESAs requires the definition of distinct classes with respect to degree of land protection from desertification.

Data in tables (28 - 34) show the classes and assigned weighing indices for the various parameters used for assessment of soil quality in the NWCZ, after Kosmas et al 1999. 
The above mentioned soil properties will be discussed as follows:

\section{a. Parent material index (Ip)}

It is noted according to its cohesion and resistance to water and wind erosion. Lithologically, (deduced from the geological maps), parent materials could be grouped into two classes as outlined below, (Table 28).

- Friable parent materials; aeolian deposits, alluvial deposits, lagoonal deposits and littoral deposits, these parent materials are susceptible to desertification and are signed with (1) as desertification sensitivity index. This group covers about $66.65 \%$ of the total study area.

- Coherent parent materials; dolomitic lime and non-friable sand stones, which are resistance to desertification and are signed with (1.7) as desertification sensitivity index, it covers about $33.35 \%$ of the total study area.

Table (28). Parent material degree with the associated areas and index at the NWCZ, Egypt

\begin{tabular}{|c|c|c|c|c|}
\hline Class & Parent material type & $\begin{array}{c}\text { Area } \\
\text { (Thousand } \\
\text { feddan) }\end{array}$ & $\underset{\%}{\text { Area }}$ & $\begin{array}{c}\text { Index } \\
(\text { Ip) }\end{array}$ \\
\hline \multirow[b]{2}{*}{1} & Aeolian deposits, littoral deposits, & \multirow[b]{2}{*}{1599.5} & \multirow[b]{2}{*}{66.65} & \multirow[b]{2}{*}{1} \\
\hline & $\begin{array}{l}\text { Lagoonal deposits, Alluvial } \\
\text { deposits, }\end{array}$ & & & \\
\hline 2 & $\begin{array}{l}\text { Limestone, sandstone, dolomatic } \\
\text { lime }\end{array}$ & 800.5 & 33.35 & 1.7 \\
\hline
\end{tabular}

\section{b. Effective soil depth index (Id)}

The soils' depth is directly related to the capacity of soil water storage; this parameter could be evaluated from the pedological maps that often do not clarified it directly. The soil depth is identified to parent rocks or soil water level, in this context the deep soils have less ability to be susceptible to desertification and vice versa, (Table 29). From the data in this table, it is quite clear that the deep soils $(>100 \mathrm{~cm})$ represent $34.19 \%$ of the total NWCZ area, where the moderately deep soils $(50-100 \mathrm{~cm})$, shallow soils (50$100 \mathrm{~cm})$ and very shallow soils $(<30 \mathrm{~cm})$ cover $0.27 \%, 34.59 \%$ and 30.32 of the total area of NWCZ, respectively. 
Table (29). Effective soil depth degrees with the associated areas and index at the NWCZ, Egypt.

\begin{tabular}{|c|l|c|c|c|}
\hline Classes & \multicolumn{1}{|c|}{$\begin{array}{c}\text { Effective soil depth } \\
(\mathbf{c m})\end{array}$} & $\begin{array}{c}\text { Area } \\
\text { (Thousand } \\
\text { feddan) }\end{array}$ & $\begin{array}{c}\text { Area } \\
(\boldsymbol{\%})\end{array}$ & $\begin{array}{c}\text { Index } \\
(\text { Id) }\end{array}$ \\
\hline 1 & Deep $>100 \mathrm{~cm}$ & 820.5 & 34.19 & 1.0 \\
\hline 2 & Mod. Deep $50-100 \mathrm{~cm}$ & 6.5 & 0.27 & 2.0 \\
\hline 3 & Shallow $30-50 \mathrm{~cm}$ & 828.75 & 34.59 & 3.0 \\
\hline 4 & Very shallow $<30 \mathrm{~cm}$ & 727.75 & 30.32 & 4.0 \\
\hline
\end{tabular}

\section{c. Soil texture index (It)}

Soil texture is related to erodibility, water retention capacity, crusting and aggregation stability. Soils high in silt content (SL) tend to have large available water holding capacity. On the opposite, sands have the smallest available water holding capacity and tend to be more prone to drought than clayey soils because they retain less water at field capacity and the water retained is consumed more rapidly by growing plants. According to water holding capacity, the soils are grouped into two classes, (Table 30).

Data in the table show the types, areas and their percentages of soil textural classes at the NWCZ. Accordingly, the texture group taken the value (1) as indicator to desertification sensitivity covers about $79.36 \%$ of the total area, meanwhile, the group taken the value (2) covers about $19.95 \%$ of the total area.

Table (30). Soil texture degrees with the associated areas and index at the NWCZ, Egypt.

\begin{tabular}{|c|l|c|c|c|}
\hline Classes & \multicolumn{1}{|c|}{ Soil texture } & $\begin{array}{c}\text { Area } \\
\text { (Thousand } \\
\text { feddan) }\end{array}$ & $\begin{array}{c}\text { Area } \\
\mathbf{( \% )}\end{array}$ & $\begin{array}{c}\text { Index } \\
\text { (It) }\end{array}$ \\
\hline 1 & $\begin{array}{l}\text { Sandy Clay Loam (SCL), Sand } \\
\text { Loam (SL), Loamy Sand (LS) }\end{array}$ & 1904.61 & 79.36 & 1.0 \\
\hline 2 & Sand (S) & 478.87 & 19.95 & 2.0 \\
\hline
\end{tabular}

\section{d. Slope gradient index (Isg)}

Slope gradient plays a paramount part in the stability of the soils. It acts directly on the amount of water determined according to the gravity of water erosion. From the topographic and digital elevation model (DEM) maps, slope gradient is classified into three classes according to its effect on soil erosion, (Table 31). Data in the table reveals that the slope gradient of 
the studied area is classified into; almost flat, gently sloping and sloping to moderately steep forming $36.52 \%, 61.87 \%$ and $0.92 \%$ of the total area, respectively.

Table (31). Soil slope degrees with the associated Areas and index at the NWCZ, Egypt.

\begin{tabular}{|c|l|c|c|c|}
\hline Classes & \multicolumn{1}{|c|}{ Slope gradient } & $\begin{array}{c}\text { Area } \\
\text { (Thousand feddan) }\end{array}$ & $\begin{array}{c}\text { Area } \\
(\boldsymbol{\%})\end{array}$ & $\begin{array}{c}\text { Index } \\
\text { (Is) }\end{array}$ \\
\hline 1 & Flat to gentle & 876.5 & 36.52 & 1.1 \\
\hline 2 & Gentle to sloping & 1485 & 61.87 & 1.2 \\
\hline 3 & Sloping to mod. Steep & 22 & 0.92 & 1.5 \\
\hline
\end{tabular}

\section{e. Rock fragments on the surface index (Ir)}

Rock fragments present on the surface are classified into three classes according to their capacity to conserve soil water and protect the soils from erosion, (Table 32). From the data in table, it is clear that the surface rock fragments are classified according to their quantities and percentage into three classes where the percentages of the surface cover are classified to $>$ $60 \%, 20-60 \%$ and $<20 \%$ and cover $23.12 \%, 33.75 \%$ and $42.44 \%$ of the total area, respectively.

Table (32). Rock fragments on the surface degrees with the associated areas and index at the NWCZ, Egypt

\begin{tabular}{|c|l|c|c|c|c|}
\hline Classes & Rock fragments & $\begin{array}{c}\text { Cover } \\
(\%)\end{array}$ & $\begin{array}{c}\text { Area } \\
\text { (Thousand } \\
\text { feddan) }\end{array}$ & $\begin{array}{c}\text { Area } \\
(\boldsymbol{\%})\end{array}$ & $\begin{array}{c}\text { Index } \\
(\mathbf{I r})\end{array}$ \\
\hline 1 & Very stony & $>60$ & 555 & 23.12 & 1.0 \\
\hline 2 & Stony & $20-60$ & 810 & 33.75 & 1.3 \\
\hline 3 & $\begin{array}{l}\text { Bare to Slightly } \\
\text { stony }\end{array}$ & $<20$ & 1018.5 & 42.44 & 2.0 \\
\hline
\end{tabular}

\section{f. Soil drainage index (Isd)}

Soil drainage has a negative relationship with soil depth, soil texture through entire layers of soil profiles, salt accumulation in the soils and occurrence of consolidated layer or not which, in turn, effect on (ESAs). The soil drainage in the studied area, (Table33), was good, imperfect and poor and cover areas represent $33.65 \%, 21.58 \%$ and $44.08 \%$ of the total area, respectively. 
Table (33). Soil drainage degrees with the associated Areas and index at the NWCZ, Egypt.

\begin{tabular}{|c|l|c|c|c|}
\hline Classes & Soil drainage & $\begin{array}{c}\text { Area } \\
\text { (Thousand feddan) }\end{array}$ & $\begin{array}{c}\text { Area } \\
(\mathbf{\%})\end{array}$ & $\begin{array}{c}\text { Index } \\
(\mathbf{I g})\end{array}$ \\
\hline 1 & Well drained & 807.5 & 33.65 & 1.0 \\
\hline 2 & Imperfectly drained & 518.0 & 21.58 & 1.2 \\
\hline 3 & Poorly drained & 1058 & 44.08 & 2.0 \\
\hline
\end{tabular}

\section{g. Soil Salinity index (Isa)}

This parameter was added to the model because it has a potential effect on the soil deterioration in the studied area. The salt content varied from slightly saline $\left(2-4 \mathrm{dSm}^{-1}\right)$, moderately saline $\left(4-8 \mathrm{dSm}^{-1}\right)$, saline (8-16 $\left.\mathrm{dSm}^{-1}\right)$ and extremely saline $\left(>16 \mathrm{dSm}^{-1}\right)$ which represent $31.92 \% ; 32.65 \%$, 32.66 and $1.08 \%$ of the total area, respectively.

The criteria affecting the soil salinity are related to the depth of groundwater table and drainage condition which are mainly responsible for salt accumulation. Data in table (34) show the distribution of salinity where $32.66 \%$ of the total area is saline meanwhile $31.92 \%$ and $33.65 \%$ are slightly saline and moderately saline, respectively.

Table (34). Soil salinity degrees with the associated Areas and index at the NWCZ, Egypt.

\begin{tabular}{|c|c|c|c|c|}
\hline Classes & $\begin{array}{c}\text { Soil salinity } \\
(\mathbf{d S} / \mathbf{m})\end{array}$ & $\begin{array}{c}\text { Area } \\
\text { (Thousand feddan) }\end{array}$ & $\begin{array}{c}\text { Area } \\
(\boldsymbol{\%})\end{array}$ & $\begin{array}{c}\text { Index } \\
(\text { Isa) }\end{array}$ \\
\hline 1 & Slight 2-4 & 766 & 31.92 & 1.2 \\
\hline 2 & Moderate 4-8 & 807.5 & 33.65 & 1.5 \\
\hline 3 & Saline 8-16 & 784 & 32.66 & 1.8 \\
\hline 4 & Very saline >16 & 26 & 1.08 & 2.0 \\
\hline
\end{tabular}

\subsubsection{Calculation of Soil Quality Index (SQI)}

Applying the arithmetic model of the soil quality index, taking into account the soil indices, the soil quality index (SQI) is calculated as follows:

$$
\mathrm{SQI}=(\mathrm{Ip} * \mathrm{Id} * \mathrm{II} * \mathrm{Isg} * \mathrm{Ir} * \mathrm{Isd} * \mathrm{Isa})^{1 / 7}
$$

Quality of the different soil properties was calculated for each soil taxonomic units to identify soil quality index in NWCZ (Tables 35 and 36) as the first step to get the sensitivity index to desertification. 


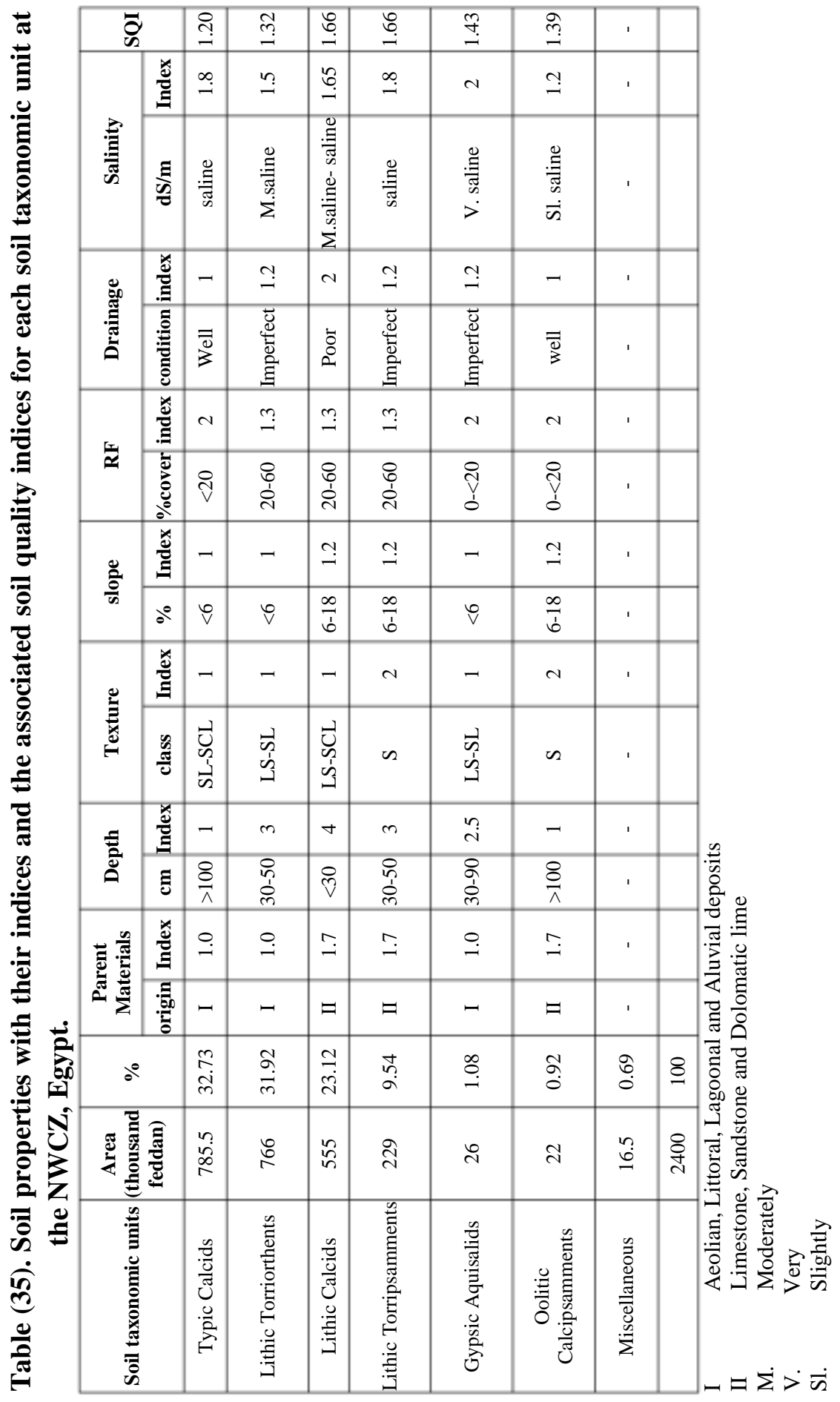

Egyptian J. Desert Res., 59, 1-96 (2009) 
Table (36). Soil taxonomic units and their soil quality Index (SQI) at the NWCZ, Egypt.

\begin{tabular}{|c|c|c|}
\hline \multirow{2}{*}{ Soil taxonomic units } & \multicolumn{2}{|c|}{ Soil quality } \\
\cline { 2 - 3 } & Index & Description \\
\hline Typic Calcids & 1.20 & Moderat \\
\hline Lithic Torriorthents & 1.32 & Moderat \\
\hline Lithic Calcids & 1.66 & Low quality \\
\hline Lithic Torripsamments & 1.66 & Low quality \\
\hline Gypsic Aquisalids & 1.43 & Moderat \\
\hline Oolitic Calcipsamments & 1.39 & Moderat \\
\hline
\end{tabular}

From the data in tables $(35,36)$, it is clear that the highest values of SQI were associated with the taxonomic units Lithic calcids and Lithic Torripsamments, whereas the lowest value is associated with the taxonomic units Typic Calcids and Lithic Torriorthent. Based on the previous quality values, soil quality index of the NWCZ was pointed out in table (37), and the data in this table reveal that the area which has moderate soil quality index (1.13-1.45) cover about $66.65 \%$ of the study area. Meanwhile, the area which has low soil quality index (>1.45) cover about $32.66 \%$, (Figure 28 ).

Table (37). Soil Quality Index of the NWCZ, Egypt.

\begin{tabular}{|c|c|c|c|c|c|}
\hline Class & Score & Description & $\begin{array}{c}\text { Area } \\
\text { (Thousand } \\
\text { feddan) }\end{array}$ & $\begin{array}{c}\text { Area } \\
\%\end{array}$ & $\begin{array}{c}\text { Index } \\
\text { (SQI) }\end{array}$ \\
\hline 1 & $<1.13$ & High quality & - & - & 1.0 \\
\hline 2 & $\begin{array}{c}1.13- \\
1.45\end{array}$ & Mod. quality & 1599.5 & 66.65 & 1.33 \\
\hline 3 & $>1.45$ & Low quality & 784 & 32.66 & 1.66 \\
\hline & & Miscellaneous & 16.5 & 0.69 & - \\
\hline
\end{tabular}

\subsection{Erosion Quality Index(EQI)}

Soil erosion by water and wind is one of the main factors of desertification in the North-Western Coastal Zone (NWCZ), because of the undulating topography, the lack of the soil structure, light soil texture, the sparsity of vegetative cover at some localities, the torrential character of rains and strong wind. As a result, different areas in the NWCZ reached the 


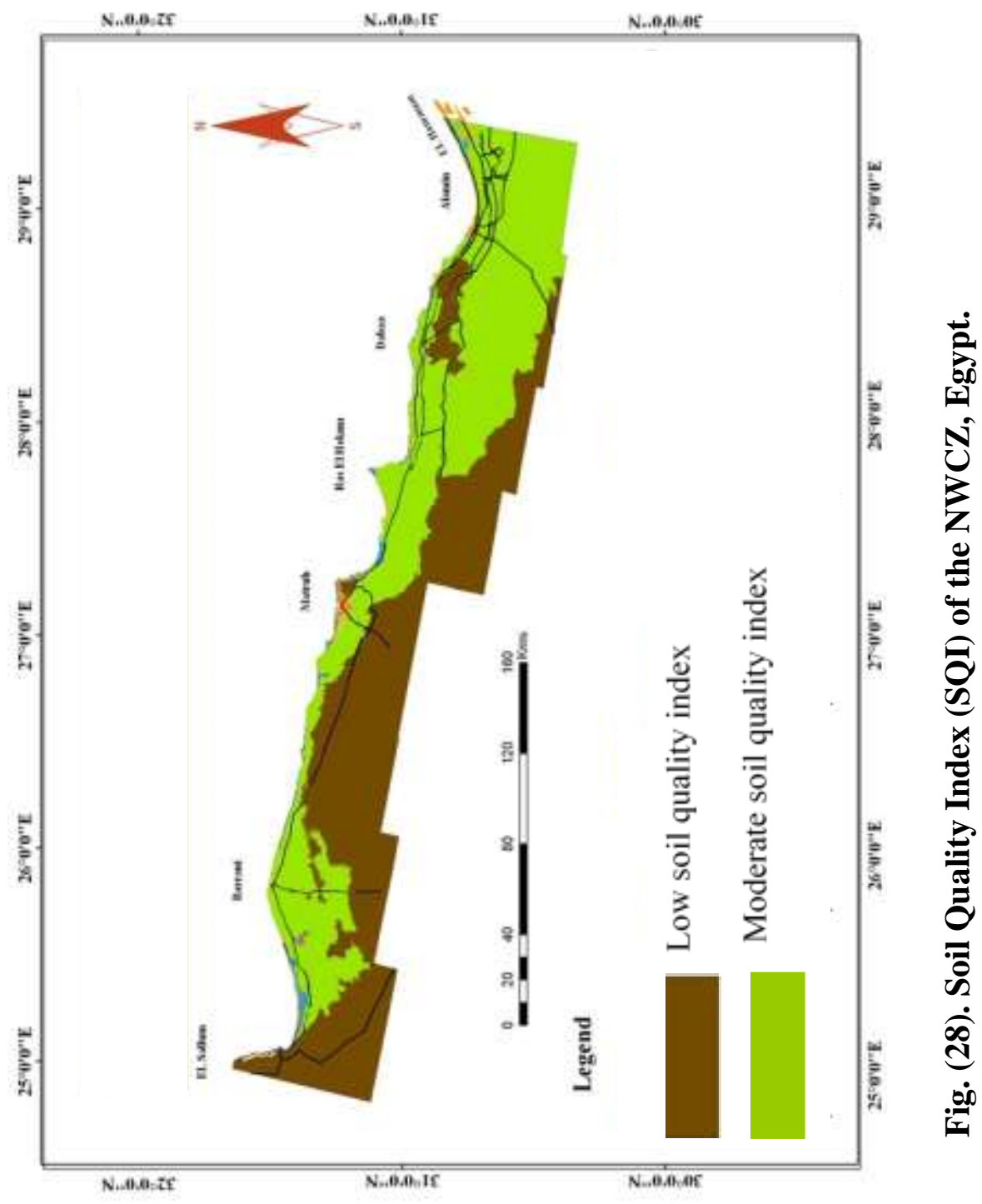

Egyptian J. Desert Res., 59, 1-96 (2009) 
irreversible state of desertification. The loss of fertile surface soil layer, resulting from soil erosion by water or wind, is considered among the process of desertification. Moreover, shallow and very shallow soil depths dominate and accelerated soil erosion hazards.

In part of the NWCZ, wind and water erosion has reached a stage of irreversibility. With a very slow rate of soil formation, any soil loss of more than $1 \mathrm{Mg} \mathrm{ha}^{-1} \mathrm{yr}^{-1}$ can be considered as irreversible within a time span of 50-100 years (Morgan, 1995)

Assessment of soil erosion rate may be based on various methods. One of these is an assessment of factor or combined factors, which affect on rate. Hereafter is the assessment of the factors affecting water and wind erosion rate under the NWCZ condition. These factors for water erosion include rainfall erosivity, soil erodibility and slope, where in case of wind erosion these factors include climate erosivity factors, soil erodibility, soil surface roughness and field length (Morgan, 1995 and LaL \& Elliot, 1994).

\subsubsection{Soil Erosion by Water}

A set of factors (indicators) related to water erosion process were evaluated at the NWCZ, these include rainfall erosivity, soil erodibility and slope factors (driving force indicators). Data of various meteorological stations along the NWCZ sectors [(Burg El Arab - El- Dabaa), (El Dabaa Um El- Rakhm), (Um El- Rakhm - Sidi Barrani) and (Sidi Barrani - El Sallum)] were selected to assess the above mentioned factors (Figure 29).

\section{i). Rainfall Erosivity (R)}

Rainfall data which included rate, period of storm and rainy days were collected from different meteorological stations along the NWCZ (Figure 29) for a five year period (1999-2004). For each storm, the rainfall erosivity index is the product of the kinetic energy of the storm at the maximum 30min. rainfall intensity of that storm $\left(\mathrm{EI}_{30}\right)$. These values of all storms that are occurring in a given year are added to give an annual erosivity index for each location. This index $(\mathrm{R})$ for each area is estimated using following equations, according to Sen Roy and Singh, (2002):

$$
\begin{gathered}
\mathrm{R}=\mathrm{EI}_{30,} \\
\mathrm{E}=11.87+8.73 \log \mathrm{I}_{30}
\end{gathered}
$$

Where: $\mathrm{R}=$ Rainfall erosivity index $\left(\mathrm{MJ} \mathrm{mm} \mathrm{ha}{ }^{-1} \mathrm{~h}^{-1}\right)$, $\mathrm{E}=$ kinetic energy $\left(\mathrm{Jm}^{-2}\right)$, and $\mathrm{I}_{30}=$ Maximum $30 \mathrm{~min}$. rainfall intensity $\left(\mathrm{mm} \mathrm{h}^{-1}\right)$.

When all data of rainfall are not available, the equation of Lal and Elliot (1994) can be used to calculate the rainfall erosivity as follows:

$$
\mathrm{R}=\left(\mathrm{P}_{\mathrm{m}}\right)^{2} / \mathrm{P}_{\mathrm{A}}
$$

Where: $P_{m}=$ monthly average rainfall $(\mathrm{mm})$, and

$\mathrm{P}_{\mathrm{A}}=$ yearly average rainfall $(\mathrm{mm})$. 


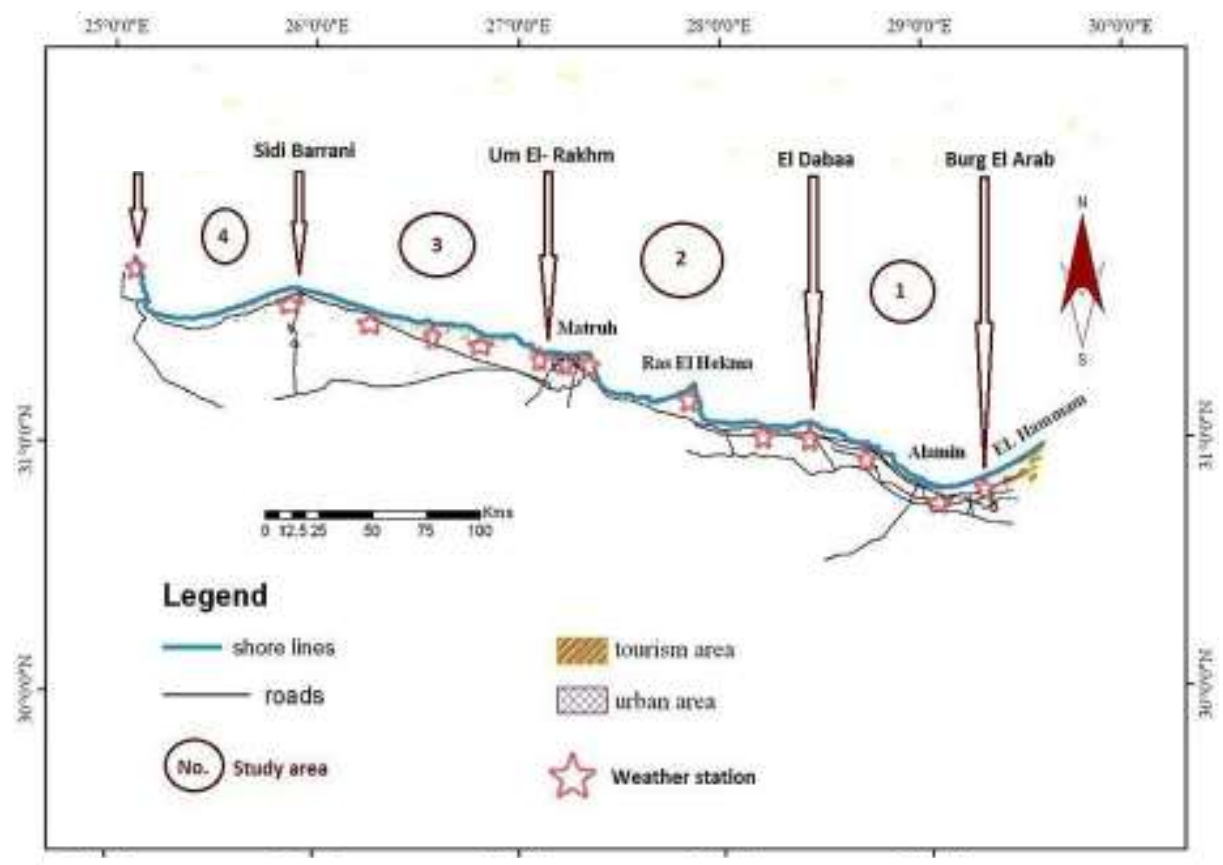

Fig. (29). Location of the meteorological stations at the NWCZ, Egypt.

The values of $(\mathrm{R})$ for the four concerned areas are given in table (38). It is clear that the highest value was obtained in Um El Rakhm-Sidi Barrani area while, the lowest one was associated with Burg El Arab-ElDabaa and Sidi Barrani-El-Sallum. In addition, the $(\mathrm{R})$ values are greater than 20 and lower than $100 \mathrm{MJ} \mathrm{mm} \mathrm{ha}^{-1} \mathrm{~h}^{-1}$ in all areas. Generally, the low values were obtained in the east and west of NWCZ; however, the relatively high values were obtained in the middle areas. According to Lal and Elliot (1994), the studied areas along NWCZ are characterized by low rainfall erosivity index. Moreover, the rainfall in the region is characterized by high intensity rainfall storms of varying duration that occur from time to time over almost all areas of the NWCZ. Soil dryness and sparse vegetation cover as well as the shallow and very shallow soil depth increased water erosion hazards particularly in the areas between El Dabaa and Sidi Barrani. 
Table (38). Average annual Rainfall erosivity index (R) in the NWCZ, Egypt.

\begin{tabular}{|c|c|}
\hline Area & $\begin{array}{r}\text { average Annual Rainfall erosivity (R) } \\
\text { MJ mm ha }{ }^{-1} \mathrm{~h}^{-1}\end{array}$ \\
\hline Burg El Arab-El Dabaa & 27.0 \\
El Dabaa-Um El Rakhm & 31.6 \\
Um El Rakhm -Sidi Barrani & 35.2 \\
Sidi Barrani-El-Sallum & 27.3 \\
\hline
\end{tabular}

Concerning the distribution of rainfall erosivity in north-south direction along the east-west direction, figure (30) shows that (R) values decreased with increasing the distance from seacoast. At El-Dabaa location, being $49.41 \mathrm{MJ} \mathrm{mm} \mathrm{ha}^{-1} \mathrm{~h}^{-1}$ near the coast and decreased to $13.6 \mathrm{MJ} \mathrm{mm} \mathrm{ha}^{-1}$ $\mathrm{h}^{-1}$ at Burg El Arab (25 km from the sea coast). Consequently, the hazards of water erosion increase near the coast and decrease along north-south direction.

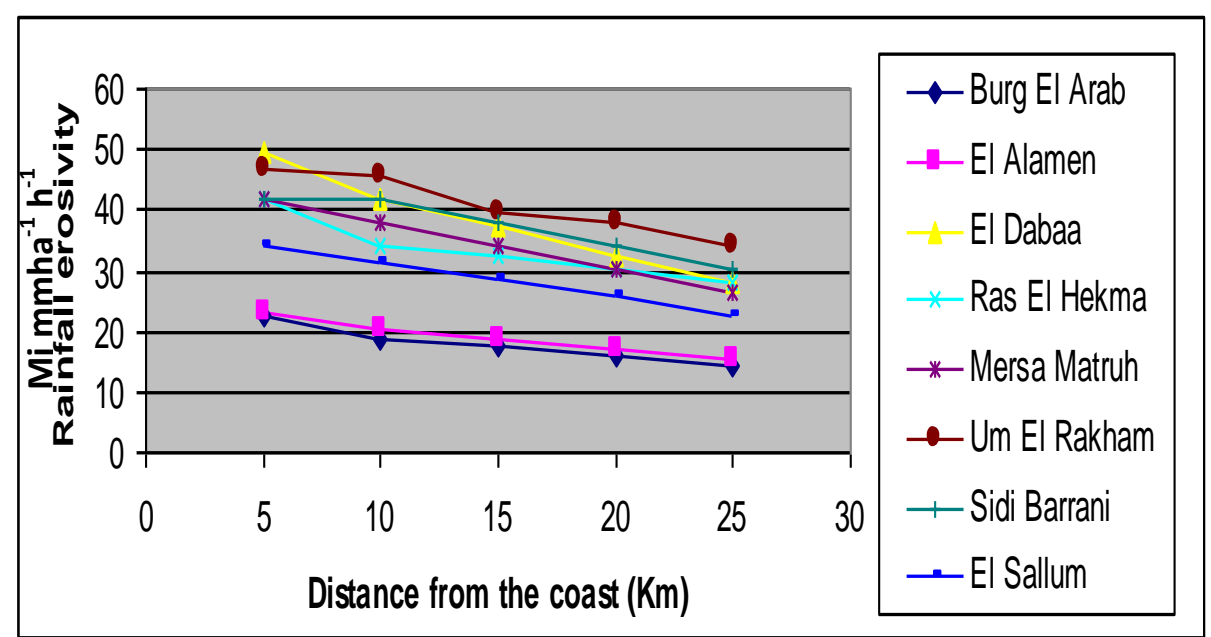

Fig. (30). The relationship between rainfall erosivity index $(\mathbf{R})$ and distance from sea coast along the NWCZ, Egypt.

\section{ii). Soil Erodibility Index (Water)}

Soil erodibility defines the resistance of the soil to both detachment and transport. Soil erodibility varies with soil texture, aggregate stability, shear strength, infiltration capacity and organic and chemical contents. Soils of the NWCZ are characterized by high percent of calcium carbonate in silt and fine sand particle sizes, low organic matter content and coarse texture. Soil erodibility values of the above mentioned areas were obtained from the 
nomograph proposed by Wischmeier and Smith (1978). The average values of soil erodibility that are given in table (39), show that they range from 0.22 to $0.27 \mathrm{Mg}$ ha h MJ $\mathrm{mm}^{-1} \mathrm{ha}^{-1}$ indicating that the studied areas along the NWCZ of Egypt occupy high soil erodibility class $(>0.2$ to $<0.4)$ according to Rousseva et al. (2012). However, soil erodibility values of some other sites of Um El Rakham - Sidi Barrani area reached $0.43 \mathrm{Mg}$ ha h $\mathrm{MJ}^{-1} \mathrm{~mm}^{-1}$ $\mathrm{ha}^{-1}$.

Table (39) Average soil erodibility by water at the NWCZ, Egypt

\begin{tabular}{|l|c|}
\hline \multicolumn{1}{|c|}{ Area } & $\begin{array}{c}\text { Average soil erodibility } \\
\left(\mathrm{Mg} \mathrm{ha} \mathrm{h} \mathrm{MJ}^{-1} \mathrm{~mm}^{-1} \mathrm{ha}^{-1}\right)\end{array}$ \\
\hline Burg El Arab-ElDabaa & 0.23 \\
El Dabaa-Um El Rakham & 0.22 \\
Um El Rakham -Sidi Barrani & 0.27 \\
Sidi Barrani-El Sallum & 0.22 \\
\hline
\end{tabular}

\section{iii) Topography Index-slope (LS)}

Water erosion would normally be expected to increase with the increases in slope steepness (S) and slope length (L) as a resulting in respective increase in velocity and volume of surface runoff. Consequently, LS is one of the effective factors of water erosion, that is calculated according to Morgan (1995) using the following equation:

$$
\mathrm{LS}=\left(\mathrm{L}^{1 / 2} / 22.13\right)\left(0.065+0.045 \mathrm{~S}+0.0065 \mathrm{~S}^{2}\right)
$$

Where $\mathrm{L}=$ slope Length $(\mathrm{m})$, and $\mathrm{S}=$ field slope steepness $(\%)$.

Calculation of slope factor (S) based on the slope steepness.

- For slopes shorter than $4 \mathrm{~m}$,

$$
\mathrm{S}=3.0\left(\operatorname{Sin} \theta^{\circ}\right)^{0.8}+0.56
$$

Where $\theta^{\circ}=$ Field slope steepness in degrees $=\tan ^{-1}(\mathrm{~S} / 100)$.

- For slopes longer than $4 \mathrm{~m}$ and $\mathrm{S}<9$ percent,

$$
\mathrm{S}=10.8 \operatorname{Sin} \theta^{\circ}+0.03
$$

- For slopes longer than $4 \mathrm{~m}$ and $\mathrm{S} \geq 9$ percent,

$$
\mathrm{S}=16.8 \operatorname{Sin} \theta^{\circ}-0.05
$$

The slope length was measured from the point where surface flow originated to the outlet channel or to a point down slope where deposition begins. The topography index (LS) of the four areas was calculated according to Morgan (1995) at three slopes percent (3\%, 5\% and 9\%). LS reached $0.44,0.88$, and 2.14 , respectively. Therefore, $\mathrm{LS}$ values are constant at certain slope steepness and slope length and such value varies according to the differences in either slope steepness or slope length. Further 
discussion on LS factor will be introduced in the part of the soil loss indicator.

\section{iv) Soil Loss by Water Erosion}

Soil loss is the onsite hazard of water erosion. It is considered one of the appropriate indicators for water erosion hazards. Two methods were used to obtain the soil loss values in the four areas at the NWCZ. The first one measured soil loss in the field by bounded runoff plots of known area, slope steepness, slope length and soil type from which both runoff and soil loss are monitored (USDA, 1995).

Bounded runoff plots of $22.1 \mathrm{~m}$ long and $2 \mathrm{~m}$ wide were used. At the downslope end, a collecting trough covered with a lid was positioned to prevent the direct entry of rainfall, from which sediment and runoff were channeled into collecting tanks. The runoff water and eroded soil were measured after each rainfall storm. In addition, Universal soil loss equation (USLE) as described by Wischmeir and Smith (1978) which includes the factors affecting water erosion process as input parameter was used. Such equation is:

Where:

\section{$\mathrm{A}=\mathrm{RKLSCP}$}

$$
\begin{aligned}
& \mathrm{A}=\text { average annual soil loss in } \mathrm{Mg} \mathrm{ha}^{-1} \mathrm{yr}^{-1} \\
& \mathrm{R}=\text { rainfall erosivity index }\left(\mathrm{MJ} \mathrm{mm} \mathrm{ha} \mathrm{hm}^{-1} \mathrm{~h}^{-1} \mathrm{yr}^{-1}\right), \\
& \mathrm{K}=\text { soil erodibility factor }\left(\mathrm{Mg} \mathrm{ha} \mathrm{h} \mathrm{MJ} \mathrm{Mm}^{-1} \mathrm{~mm}^{-1} \mathrm{ha}^{-1}\right), \\
& \mathrm{LS}=\text { topography factor (dimensionless) } \\
& \mathrm{C}=\text { cover management factor (dimensionless), and } \\
& \mathrm{P}=\text { conservation practice factor (dimensionless). }
\end{aligned}
$$

The values of soil loss of different locations in the four areas varied in LS factor are given in table (40). It is clear that the values differ widely between 2.8 and $18.75 \mathrm{Mg} \mathrm{ha}^{-1} \mathrm{yr}^{-1}$. These values indicate that the level of water erosion rate ranged between slight to moderate according to Salter (1984). In all areas, soil loss values increase with increasing LS factors.

\subsubsection{Soil Erosion by Wind}

At the NWCZ, wind erosion plays an important role in land degradation and desertification. The causative factors are the following,

- Low annual rainfall which varies from 100 to $150 \mathrm{~mm}$ where most of the rain falls during November to March.

- Winds blow strongly during winter and early spring with an average speed of about 5.5 to $7.0 \mathrm{~m} / \mathrm{s}$, the wind speed decreases in May and June but July is windy and the end of summer records many calm days. 
- Coarse-textured soils, the lack of soil structure, the sparse vegetation cover, low organic matter content, high content of calcium carbonate, long dry periods (more than 6 months) and the torrential characteristics of the rain.

Table (40). Soil loss $\left(\mathrm{Mg} \mathrm{ha}^{-1} \mathrm{yr}^{-1}\right)$ due to water erosion as affected by $\mathrm{LS}$ factor at the NWCZ, Egypt.

\begin{tabular}{|c|c|c|c|c|}
\hline \multirow{2}{*}{ Area } & \multirow{2}{*}{ Location } & \multicolumn{3}{|c|}{ LS factors } \\
\hline & & 0.81 & 0.44 & 2.14 \\
\hline $\begin{array}{c}\text { Burg El Arab - El } \\
\text { Dabaa }\end{array}$ & $\begin{array}{c}\text { Burg Al Arab } \\
\text { El Alameen } \\
\text { Sidi Abdel Rahman } \\
\text { East El Dabaa }\end{array}$ & $\begin{array}{l}3.3 \\
2.8 \\
4.3\end{array}$ & 6.3 & $\begin{array}{c}15.2 \\
- \\
- \\
4.2\end{array}$ \\
\hline Average & & 3.5 & 6.3 & 9.7 \\
\hline $\begin{array}{c}\text { El Dabaa - Um El } \\
\text { Rakhm }\end{array}$ & $\begin{array}{l}\text { W. Hreqa } \\
\text { W. Hashem } \\
\text { Un El Rakhm } \\
\text { El Qasr }\end{array}$ & $\begin{array}{c}- \\
- \\
3.8 \\
4.0\end{array}$ & $\begin{array}{c}18.75^{*} \\
13.25^{*} \\
7.10 \\
5.3^{*}\end{array}$ & - \\
\hline Average & & 3.9 & 11.1 & - \\
\hline $\begin{array}{c}\text { Um El Rakhm - } \\
\text { Sidi Barrani }\end{array}$ & $\begin{array}{c}\text { W. Habis } \\
\text { El Nekhela } \\
\text { El Mathani } \\
\text { East Sidi Barrani }\end{array}$ & $\begin{array}{l}3.8 \\
4.0 \\
6.7\end{array}$ & $\begin{array}{c}11.5^{*} \\
8.6 \\
8.1\end{array}$ & $\begin{array}{c}- \\
7.8 \\
- \\
11.7\end{array}$ \\
\hline Average & & 4.8 & 9.4 & 9.75 \\
\hline $\begin{array}{l}\text { Sidi Barrani - } \\
\text { El-Sallum }\end{array}$ & $\begin{array}{l}\text { West Sidi Barrani } \\
\text { Sidi Barrani } \\
\text { East El-Sallum } \\
\text { West El-Sallum }\end{array}$ & $\begin{array}{c}- \\
- \\
2.9\end{array}$ & $\begin{array}{c}- \\
5.9 \\
-\end{array}$ & $\begin{array}{c}11.7 \\
- \\
- \\
15.3\end{array}$ \\
\hline Average & & 2.9 & 6.4 & 13.5 \\
\hline
\end{tabular}

*: measured soil loss using bounded runoff plots.

To assess the current status of wind erosion process in the NWCZ, the factors of wind erosion were measured and some of them are used as indicators of wind erosion hazards. The first factor is climatic erosivity factor which can be used as a driving force indicator and it is considered as the main factor controlling the broad pattern of wind erosion. Such factor varies according to wind velocity, temperature, evaporation and rainfall. The second factor is soil erodibility which is related to soil properties. 
Calculation of soil erodibility is based on the percentage of non-erodible soil fraction (aggregates $>0.84 \mathrm{~mm}$ in diameter). Other factors such as soil surface roughness, vegetation cover, field length, shape, and slope gradient of the area affect wind erosion rate.

This part includes climatic erosivity and soil erodibility factors as wind erosion indicators. In addition, soil loss by wind erosion was either measured (Fryrear, 1986) or estimated (Woodruff \& Siddoway, 1965) is included.

\section{i) Climatic Erosivity Factor (C)}

Monthly data that were obtained from El Hammam, El Dabaa, Fuka, Sidi Abdel Rahman, El Qasr, Abu Lahu, and El-Sallum metreological stations to be used for estimating the climatic erosivity index, specifically wind speed and surface soil moisture that is expressed as a percentage of the C factor, that has been assigned by (Lyles et al. 1983). The climatic factors equation is expressed as:

$$
\mathrm{C}=386 \mathrm{U}^{3} /(\mathrm{PE})^{2}
$$

Where:

$\mathrm{C}$ is the annual climatic factor (dimensionless), and

$\mathrm{U}$ is the average annual wind velocity $(\mathrm{m} / \mathrm{s})$ at $9.15 \mathrm{~m}$ from soil surface.

PE is the precipitation-effectiveness index of Thornthwaite (1931), which is calculated using the following equation:

$$
\mathrm{PE}=3.16 \sum\left[\mathrm{P}_{\mathrm{i}} /\left(1.8 \mathrm{~T}_{\mathrm{i}}+22\right)\right]^{10 / 9}
$$

Where: $\mathrm{P}_{\mathrm{i}}$ is monthly precipitation in $\mathrm{mm}$, and

$\mathrm{T}_{\mathrm{i}}$ is the average monthly air temperature in ${ }^{\circ} \mathrm{C}$.

The climatic erosivity factor (C) was calculated for the concerned four areas and the values are given in table (41), which shows that $C$ factor varied from 2.8 to 5.2. These values are greater than 2 , which reveal that the four areas of the NWCZ are subjected to highly erosive climatic conditions. According to Chepil et al. (1963) all areas of the NWCZ are subjected to the hazards of wind erosion at different levels. 
Table (41). Climatic erosivity factor (C) of wind erosion at the NWCZ, Egypt (Sharkawy, 2006).

\begin{tabular}{|c|c|}
\hline Area & Average C factor \\
\hline Burg El Arab - El Dabaa & 2.8 \\
El Dabaa - Um El Rakhm & 4.5 \\
Um El Rakhm -Sidi Barrani & 4.8 \\
Sidi Barrani - El-Sallum & 5.2 \\
\hline
\end{tabular}

\section{ii) Soil Erodibility by Wind (I)}

As mentioned before, NWCZ soils are characterized by coarse texture, low organic carbon content and high percent of calcium carbonate. Some references indicated that decreasing organic carbon less than $3 \%$, increases vulnerability to erodibility by wind erosion.

The soil erodibility factor (I) is related to the percentage of nonerodible surface which is represented by soil aggregates larger than $0.84 \mathrm{~mm}$ in diameter that can be determined by dry sieving method. Soil erodibility of the $(0-5 \mathrm{~cm}$ depth) of several locations in the four areas of NWCZ was determined according to Woodruff and Siddoway (1965) method, which is based on the non-erodible aggregates $(>0.84 \mathrm{~mm}$ in diameter). Soil erodibility index $\left(\mathrm{Mg} \mathrm{ha}^{-1} \mathrm{yr}^{-1}\right)$ is inversely logarithmic correlated with nonerodible soil aggregates (\%). The soil erodibility indices range between 0 and $560 \mathrm{Mg} \mathrm{ha}^{-1} \mathrm{yr}^{-1}$.

Soil erodibility values of the four areas under consideration are given in table (42) and ranging between 168.5 and $207.3 \mathrm{Mg} \mathrm{ha}^{-1} \mathrm{yr}^{-1}$ in the bare soil. These values indicate that the level of soil erodibility by wind erosion is high according to Morgan (1995); consequently, soils of NWCZ have high sensitivity to wind erosion hazards.

Table (42). Soil erodibility by wind erosion at the NWCZ, Egypt.

\begin{tabular}{|c|c|}
\hline Area & $\begin{array}{c}\text { Average soil erodibility by wind erosion } \\
\left(\mathrm{Mg} \mathrm{ha}^{-1} \mathrm{yr}^{-1}\right)\end{array}$ \\
\hline Burg El Arab - El Dabaa & 168.5 \\
El Dabaa - Um El Rakhm & 200.0 \\
Um El Rakhm -Sidi Barrani & 205.3 \\
Sidi Barrani - El-Sallum & 207.3 \\
\hline
\end{tabular}

\section{iii) Soil Loss}

The wind erosion equation has been applied in several locations in the four areas of NWCZ (Figure 29). The equation described by Woodruff and 
Siddoway (1965) calculates potential average annual erosion rates as follows:

Where:

$$
E=f(I, K, C, L, V)
$$

$\mathrm{E}$ is the potential annual soil loss $\left(\mathrm{Mg} \mathrm{ha}^{-1} \mathrm{yr}^{-1}\right)$,

I is the soil erodibility, expressed as potential annual soil loss in $\mathrm{Mg}$ $\mathrm{ha}^{-1} \mathrm{yr}^{-1}$ from a wide, unsheltered isolated field with bare, smooth, level, loose and non-crusted surface,

$\mathrm{K}$ is the surface roughness factor, which is a measure of the effect of ridges made by tillage and planting implements, or other means of creating systemically spaced ridges (dimensionless),

$\mathrm{C}$ is an index of climatic erosivity, specifically wind- speed and surface soil moisture; the factor for any given location is based on long-term climatic data and is expressed as a percentage of the $\mathrm{C}$ factor (dimensionless),

$\mathrm{L}$ is the unsheltered, weighted travel distance (m) along the prevailing wind erosion, and

$\mathrm{V}$ is the equivalent vegetative cover expressed by relating the kind, amount, and orientation of vegetative material to its equivalent in $\mathrm{kg} \mathrm{ha}^{-1}$ of small grain residue.

The values of soil loss are 28.6, 10.6, 19.9, and 36.07 $\mathrm{Mg} \mathrm{ha}^{-1} \mathrm{yr}^{-1}$ for four locations (Burg El Arab - El Dabaa), (El Dabaa - Um El Rakhm), (Um El Rakhm - Sidi Barrani) and (Sidi Barrani - El-Sallum), respectively. According to Salter (1984) and Shrestha (1997), these values indicate that the hazards of soil erosion by wind are moderate to severe, for the soils characterized by shallow depth, coarse texture, and scarcity of natural vegetation. Consequently, wind erosion is the main process of desertification and is considered a major problem for agriculture development the NWCZ.

\subsubsection{Calculation of Erosion Quality Index}

Soil erosion refers to a series of processes leading to soil depletion in site and transportation of sediments elsewhere. It is one of the major processes of desertification and land degradation. Water and wind erosion can be assessed via parameters related to weather, soil erodibility, soil roughness and management including vegetation and the applied soil protective practices.

As for the inclusion of soil erosion, expressed by the total soil loss, as an indicator in assessing the sensitivity of ecosystems for desertification, Kosmas et al (1999) showed that such indicator is involved in the proposed three quality indices, i.e. soil quality index (SQI), climatic quality index, vegetation quality index (VQI). Nevertheless, other investigators e.g. Rose (1998) and Fryrear (2000) showed that there is no direct analogue in wind erosion to rainfall detachment where the saltation flux in wind erosion is 
approximately proportional to wind power, which is not the case for sediment flux in water. They do not have the highly sensitive dependence on surface water content compared to wind erosion.

Moreover, the climatic quality index (CQI) suggested by Kosmas et al. (1999) depended only on the values of annual amount of rainfall (mm) and the potential evapotranspiration, (aridity index), which may be considered improper approximation for expressing the kinetic energy of rainfall and the velocity of the overland mass movement of water erosion.

Average quantities of soil loss by water erosion were measured or estimated using bounded plots or Universal Soil Loss Equation (USLE\}, respectively, whereas quantities of soil loss by wind erosion were measured or estimated using Big Spring Number Eight (BSNE) or Wind Erosion Equation (WEQ), respectively, during the period between the years 2000 and 2010. Water erosion hazard index (WEHI) and wind erosion hazard index $\left(\mathrm{W}_{\mathrm{i}} \mathrm{EHI}\right)$ were calculated using the following equations:

$$
\begin{aligned}
& \mathrm{WEHI}=(\text { Soil loss by water erosion })^{1 / 5} \\
& \mathrm{~W}_{\mathrm{i}} \mathrm{EHI}=(\text { Soil loss by wind erosion })
\end{aligned}
$$

Erosion Hazards Index (EHI) was calculated based on the original model of Mediterranean Desertification and Land Use (MEDALUS) according to Kosmas et al. (2003) by the following equation:

$$
\mathrm{EHI}=\left[(\mathrm{WEHI}) \times\left(\mathrm{W}_{\mathrm{i}} \mathrm{EHI}\right)\right]^{1 / 2}
$$

Data in table (43) show the soil loss and hazard index of soil erosion by water and wind for each selected area. Worthy to mention that the trend classes of erosion hazard index or water erosion hazard index or wind erosion hazard index is Low $(0.8$ to $<1.58)$, Moderate $(\geq 1.58$ to $<1.82)$, and High $(\geq 1.82)$. These classes are opposite of the Erosion Quality Index (EQI), (Table 44).

The values of WEHI and $\mathrm{W}_{\mathrm{i}} \mathrm{EHI}$, (Table 43), were used for assessing the Erosion Quality Index (EQI) according to the following formula;

$$
\mathrm{EQI}=\left(\mathrm{WEHI} \times \mathrm{W}_{\mathrm{i}} \mathrm{EHI}\right)^{1 / 2}
$$


Table (43). Soil loss and hazard index of soil erosion by water and wind for each area at the NWCZ, Egypt.

\begin{tabular}{|c|c|c|c|c|}
\hline Erosion type & \multicolumn{2}{|c|}{ Water erosion } & \multicolumn{2}{c|}{ Wind erosion } \\
\hline Area & $\begin{array}{c}\text { Soil loss } \\
\mathrm{Mg} \mathrm{ha}^{-1} \mathrm{yr}^{-1}\end{array}$ & $\begin{array}{c}\text { Hazard } \\
\text { Index }\end{array}$ & $\begin{array}{c}\text { Soil loss } \\
\mathrm{Mg} \mathrm{ha}^{-1} \mathrm{yr}^{-1}\end{array}$ & Hazard Index \\
\hline Burg El Arab - El Dabaa & 5.40 & 1.40 & 39.90 & 2.10 \\
\hline El-Dabaa -Matruh & 8.90 & 1.54 & 26.60 & 1.93 \\
\hline Matruh - Um El Rakhm & 5.80 & 1.42 & 10.60 & 1.60 \\
\hline Um El Rakhm -Sidi Barrani & 7.20 & 1.48 & 36.07 & 2.04 \\
\hline Sidi Barrani - El-Sallum & 6.70 & 1.46 & 27.80 & 1.94 \\
\hline
\end{tabular}

Table (44). The classes of soil loss and erosion quality index.

\begin{tabular}{|c|c|c|c|}
\hline Class & Description & $\begin{array}{c}\text { Soil loss } \\
\mathbf{M g ~ h a}^{-1} \mathbf{y r}^{-\mathbf{1}}\end{array}$ & Erosion quality index \\
\hline 1 & High quality & $<10$ & 0.8 to $<1.58$ \\
\hline 2 & Moderate quality & $10-20$ & $\geq 1.58$ to $<1.82$ \\
\hline 3 & Low quality & $>20$ & $\geq 1.82$ \\
\hline
\end{tabular}

The obtained values of erosion quality index are given in table (45) and evaluated with the values given in table (44).

Table (45). Soil erosion quality index of the selected areas at the NWCZ, Egypt.

\begin{tabular}{|c|c|c|}
\hline Area & EQI & $\begin{array}{c}\text { Erosion } \\
\text { Quality }\end{array}$ \\
\hline Burg El Arab - El Dabaa & 1.7 & Moderate \\
\hline El-Dabaa - Matrouh & 1.7 & Moderate \\
\hline Matrouh - Um El Rakhm & 0.8 & High \\
\hline Um El Rakhm - Sidi Barrani & 1.7 & Moderate \\
\hline Sidi Barrani - El-Sallum & 1.7 & Moderate \\
\hline
\end{tabular}

Figure (31) represents the layer of soil erosion quality index of the NWCZ. Data in table (45). The figure indicates that the NWCZ is dominated by moderate erosion quality class, where there are, overgrazing, high intensity of some rainfall storm, high wind speed, long dry period and mismanagement practices with weak soil structure and low organic matter content which make the soils of NWCZ are very sensitive to soil erosion either by water or by wind. 


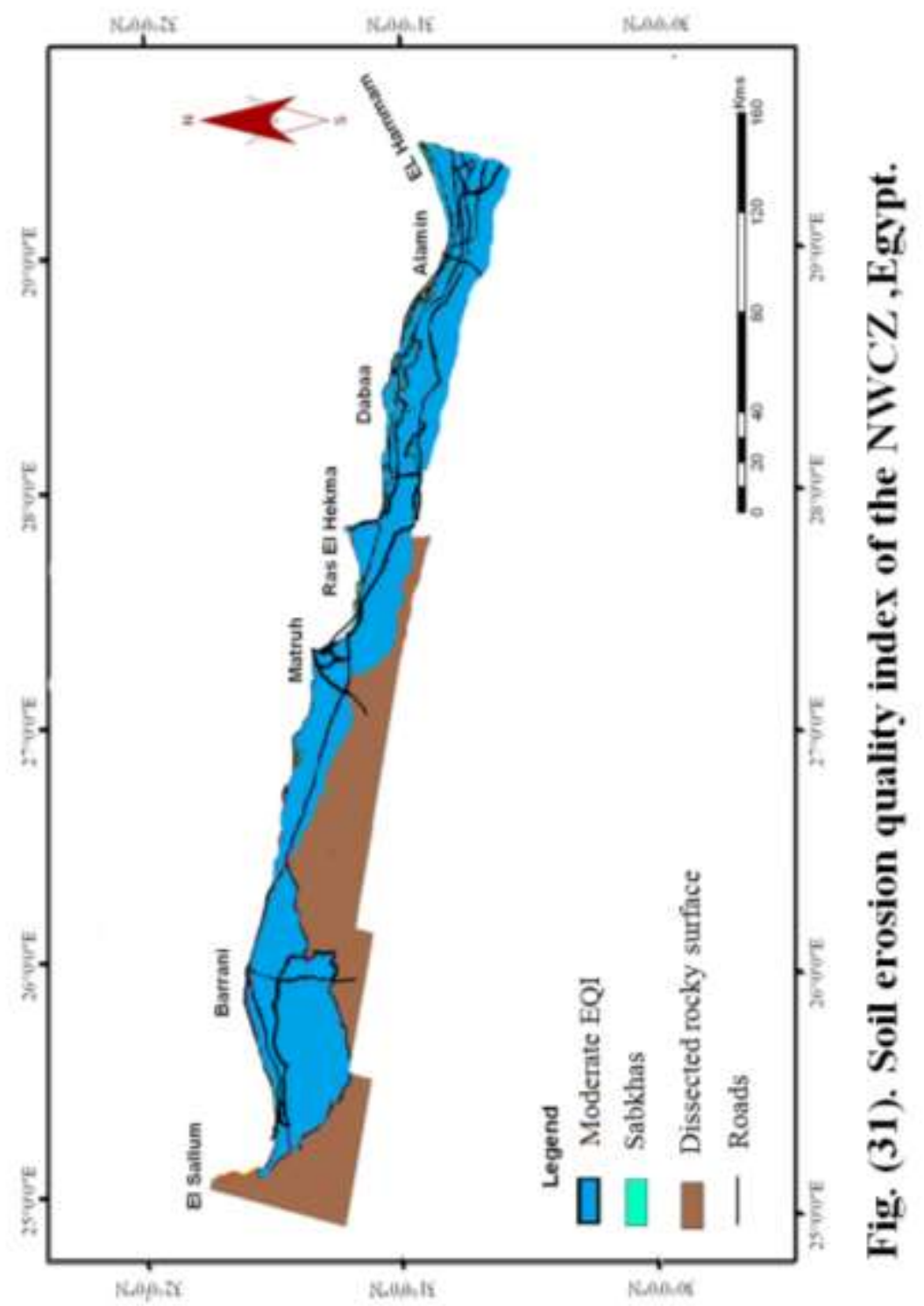

\subsection{Vegetation Quality Index (VQI)}

It is well known that the growth of a given type of plant cover in an area depends upon its climatic setting; (precipitation, evapotranspiration and temperature). Under arid conditions, climatic factors control the degree and rate of erosion by either wind or runoff. It was observed that rainfed areas cultivated with fruit trees or crops are more sensitive to erosion and

Egyptian J. Desert Res., 59, 1-96 (2009) 
desertification. This is attributed to the lack of protection with natural plant cover.

Perennial plants, like olive, grape, fig and almond, which are commonly raised in the coast and which need to prune operation, in addition to annual cultivations in between are subjected to erosion by winds and runoff, while soil loss in areas with perennial cover of trees and natural vegetation, is very limited.

It was observed that cultivation with evergreen trees protect the soil against erosion, compared to those cultivated with annual crops. Natural vegetation is considered as one of the most important factors, which increase the combating of desertification, though overgrazing results in lack of plant cover or decrease it, (grazing risk). The grazing risk is used in the mathematical formula which measures the degree of desertification (Kosmas et al., 1999).

Commonly, ecosystems of the NWC have high ability for drought resistance. Most of the growing plants can resist drought for long periods even when the soil moisture content is lower than the theoretical wilting point. Plant cover types can be grouped in descending order according to their ability to resist drought as follows:

1- Perennial, evergreen trees (olive)

2- Perennial, deciduous trees (fig \& grape).

3- Natural plant covers (range, medicinal and aromatic plants).

4- Annual field crops (barley \& wheat).

Limitation on vegetation quality index (VQI) for desertification mainly depends on the following indicators; ratio of plant cover, drought resistance, types of plant erosion protection, either natural or cultivated, and grazing risk.

Rating values for each of the above-mentioned 4 factors were adapted on basis of OSS (2004) as shown in tables (46-49), these factors were used to calculate vegetation quality index (VQI), as follows:

VQI $=(\text { vegetation cover } * \text { Drought resistance } * \text { Erosion protection } * \text { Grazing risk })^{1 / 4}$

Table (46). The percentage of vegetation cover.

\begin{tabular}{|c|c|c|c|}
\hline Class & Description & Plant cover (\%) & Index \\
\hline 1 & High & $>40 \%$ & 1 \\
\hline 2 & Low & $10-40 \%$ & 1.8 \\
\hline 3 & Very low & $<10 \%$ & 2 \\
\hline
\end{tabular}


Table (47). Types of plant drought resistance.

\begin{tabular}{|c|c|c|c|}
\hline Class & Description & Type of vegetation & Index \\
\hline 1 & Very high & Tamarix nilotica trees and reefs & 1 \\
\hline 2 & High & $\begin{array}{c}\text { Atriplex halimus } \text { and succulent } \\
\text { species }\end{array}$ & 1.2 \\
\hline 3 & Moderate & $\begin{array}{c}\text { Perennial agricultural crops \& } \\
\text { orchards }\end{array}$ & 1.4 \\
\hline 4 & Low & Cereals, grasslands, vines & 1.7 \\
\hline 5 & Very low & Annuals & 2 \\
\hline
\end{tabular}

Table (48). Types of plant erosion protection.

\begin{tabular}{|c|c|c|c|}
\hline Class & Description & Type of vegetation & index \\
\hline 1 & High & Wetlands with trees and shrubs & 1 \\
\hline 2 & Moderate & Evergreen and mound forming shrubs & 1.3 \\
\hline 3 & Low & Perennial agriculture, orchards & 1.6 \\
\hline 4 & Very low & Annuals, agricultural crops & 2 \\
\hline
\end{tabular}

Table (49). Grazing risk.

\begin{tabular}{|c|c|c|c|}
\hline Class & Description & Type of vegetation & index \\
\hline 1 & Very high & Annuals and palatable shrubs & 1 \\
\hline 2 & High & Orchards and evergreen shrubs & 1.3 \\
\hline 3 & Moderate & Grasslands and agriculture fields & 1.6 \\
\hline 4 & Low & Trees, bushes and succulent halophytes & 2 \\
\hline
\end{tabular}

*Vegetation quality index was evaluated as shown in table (50).

Table (50). Evaluation of vegetation quality index.

\begin{tabular}{|c|c|c|}
\hline Class & Description & index \\
\hline 1 & High quality & $<1.6$ \\
\hline 2 & Moderate quality & $1.7-3.7$ \\
\hline 3 & Low quality & $>3.8$ \\
\hline
\end{tabular}

For the indication of plant cover type in the NW coast in correspondence to the limitation on the sensitivity range of the environment for desertification, six transects were studied, starting from north 
(Mediterranean) to southward with lengths of $10-15 \mathrm{~km}$, beginning from Burg El Arab eastward to Sidi Barrani in the west. These include; Burg El Arab, El Dabaa, Ras El-Hekma, Matruh, El Nigela and Sidi Barrani. Classification of these transects was carried out using satellite images (Spot 4) with different classes representing vegetation in six sites of each transect.

Condensed field work has been carried out in the period May - June, 2010 using GPS to indicate the following:

1- Vegetation cover ratio.

2- Drought resistant plants

3- Plant species which tolerate erosion.

4- Grazing risk.

In the following, a description of the studied transects and the corresponding (VQI) is given starting from Burg El-Arab in the east to Sidi Barrani in the west (Tables 51 - 56) and (Figure 32):

\section{a- Burg El-Arab transect}

This transect is distinguished by apparent variability in plant habitat and plant species in addition to high ratio of plant cover, compared to other transects.

Data in table (51) indicate that there is a variation in natural plant cover at this transect, where at site 1, the dominant is Thymelaea hirsuta and at site 2, Tamarix nilotica dominates. At site 3, Ficus carica dominates other cultivations, where the other three sites $(4,5 \& 6)$ are newly reclaimed lands cultivated with crops beside the existence of wild plants.

Vegetation quality index ranged from low quality (1.65-1.87) at sites 1 and 4 to moderate quality (1.19-1.34) at other sites (2,3,5 and 6).

\section{b- El-Dabaa Transect}

Data in table (52) indicate that the natural plant cover at site 1 , is dominated by Thymus capitatus where at Site 4, Olea europaea is the dominant.At site 5, the dominance is to Thymelaea hirsuta.

Vegetation quality index value was moderate at site $4,(1.41)$ whereas at sites 1 and 5, VQI were low and (1.41-1.53).

\section{c- Ras El-Hekma Transect}

Results that are given in table (53) indicate that the dominant plants were Asphodelus ramosus, Suaeda futicosa, Salsola tetrandra, Ficus carica, Thymelaea hirsuta and Olea europaea, at sites 1,2,3,4,5 and 6, respectively, whereas sites 4 and 6 represent areas prepared for cultivation or already cultivated.

Vegetation quality index values were low at all sites and ranged between 1.59 and 1.89 , except at site 3 and Olea europaea, is moderate (1.1.29).

\section{d- Mersa Matruh Transect}

Data in table (54) indicate that the dominant plant cover was Haloxylon scoparia at sites 2,4 and 6 where the dominant ones at sites 3 and 
5 were Haloxylon salicornicum and Thymalaea hirsute, respectively. Values of vegetation quality index were low and ranged between 1.76 and 1.89.

e- El-Nigela Transect

Sites 1,2 and 6 of this transect were dominated by Thymelaea hirsuta. (Table 55) where sites 4 and 5 were dominated by Haloxylon scoparia, but as for site 3 the dominancy was to Atriplex nummularia. Values of vegetation quality index is low (1.41-1.89).

\section{f- Sidi Barrani Transect}

The dominant plant cover at sites 3, 4, 5 is Haloxylon scoparia (Table 56). Where Olea europaea and Thymalaea hirsuta were the dominant at sites 2 and 6 . Values of vegetation quality index ranged between 1.41 to 1.89 which is low.

Egyptian J. Desert Res., 59, 1-96 (2009) 


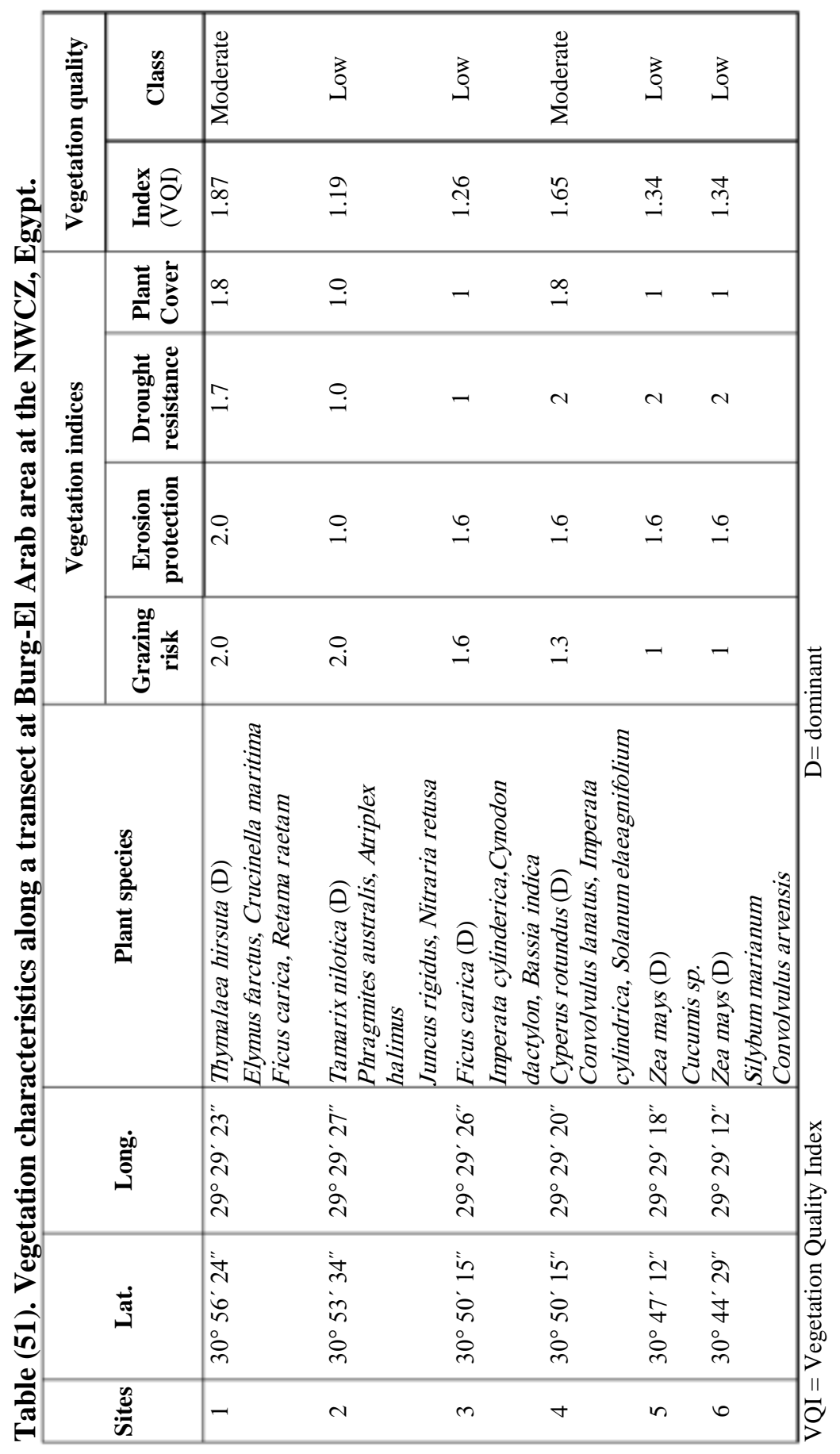

Egyptian J. Desert Res., 59, 1-96 (2009) 


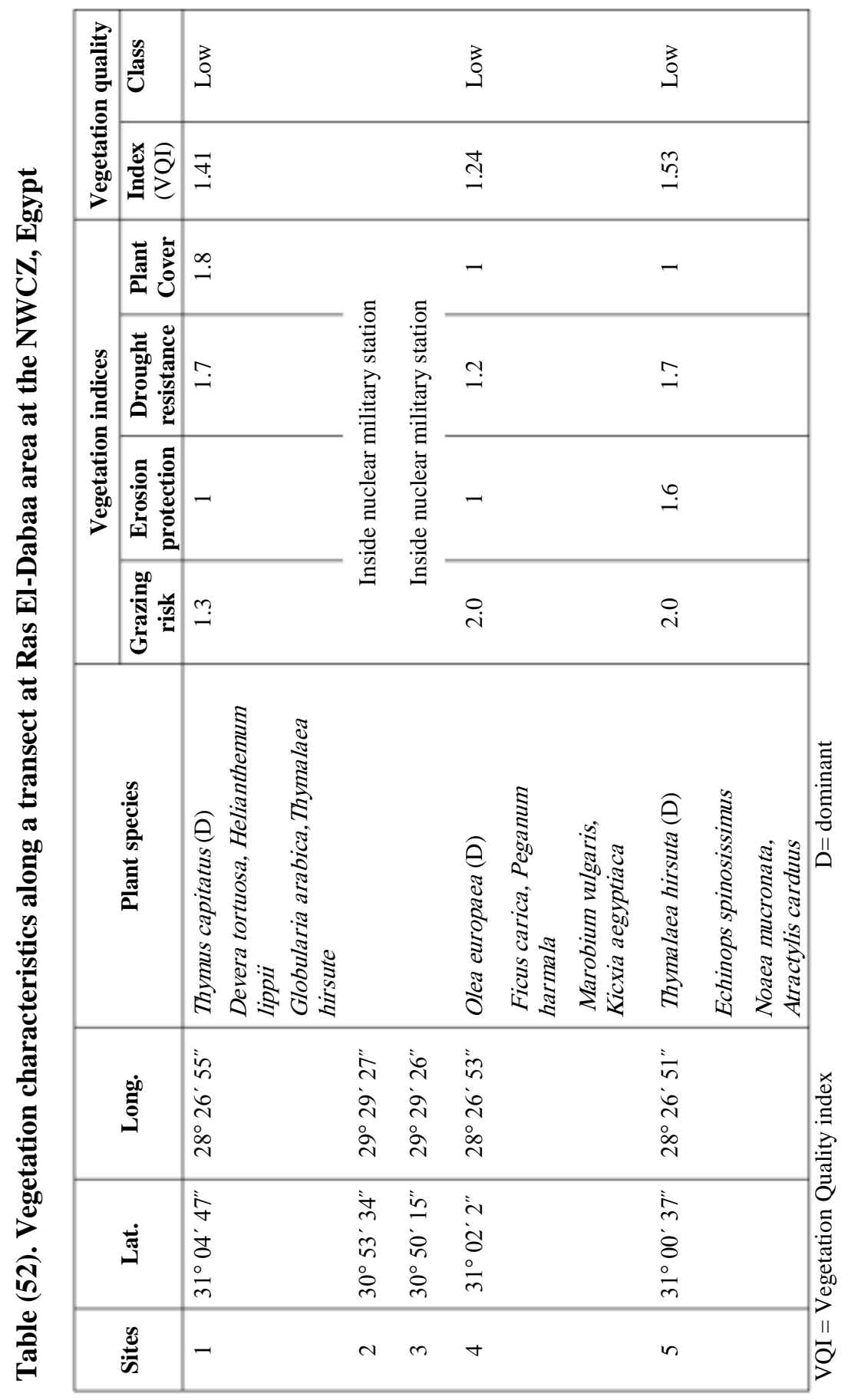

Egyptian J. Desert Res., 59, 1-96 (2009) 


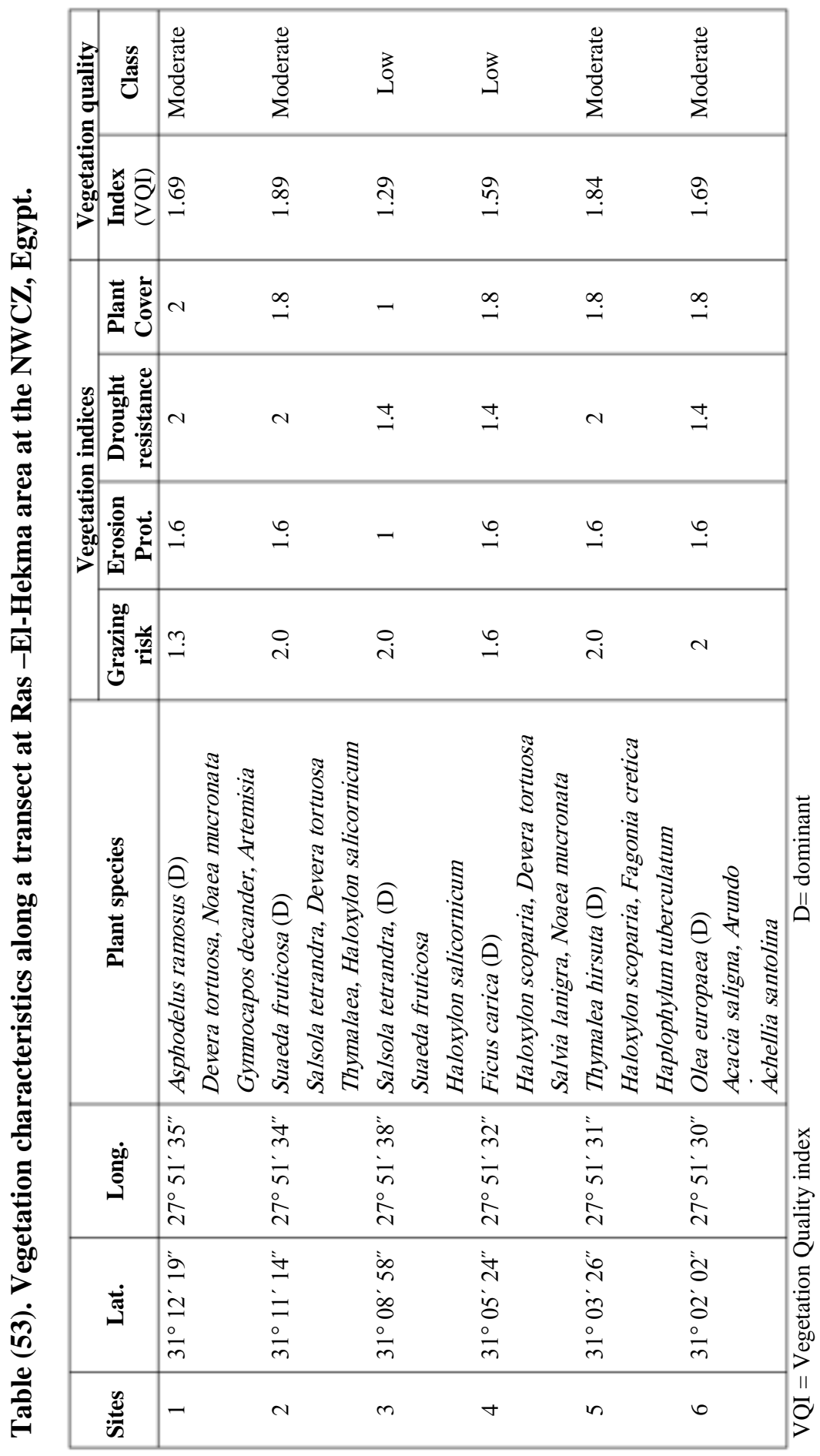

Egyptian J. Desert Res., 59, 1-96 (2009) 


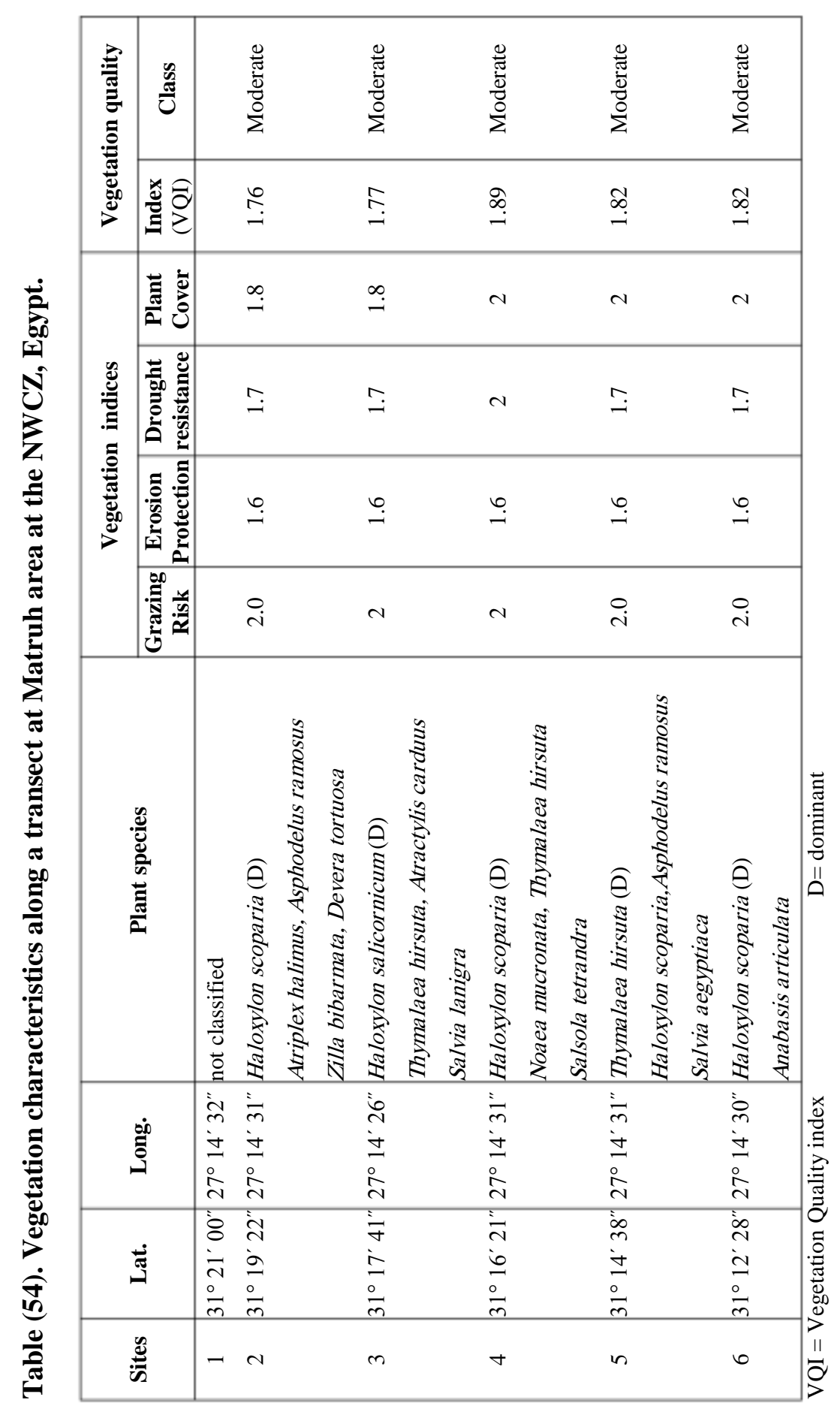

Egyptian J. Desert Res., 59, 1-96 (2009) 


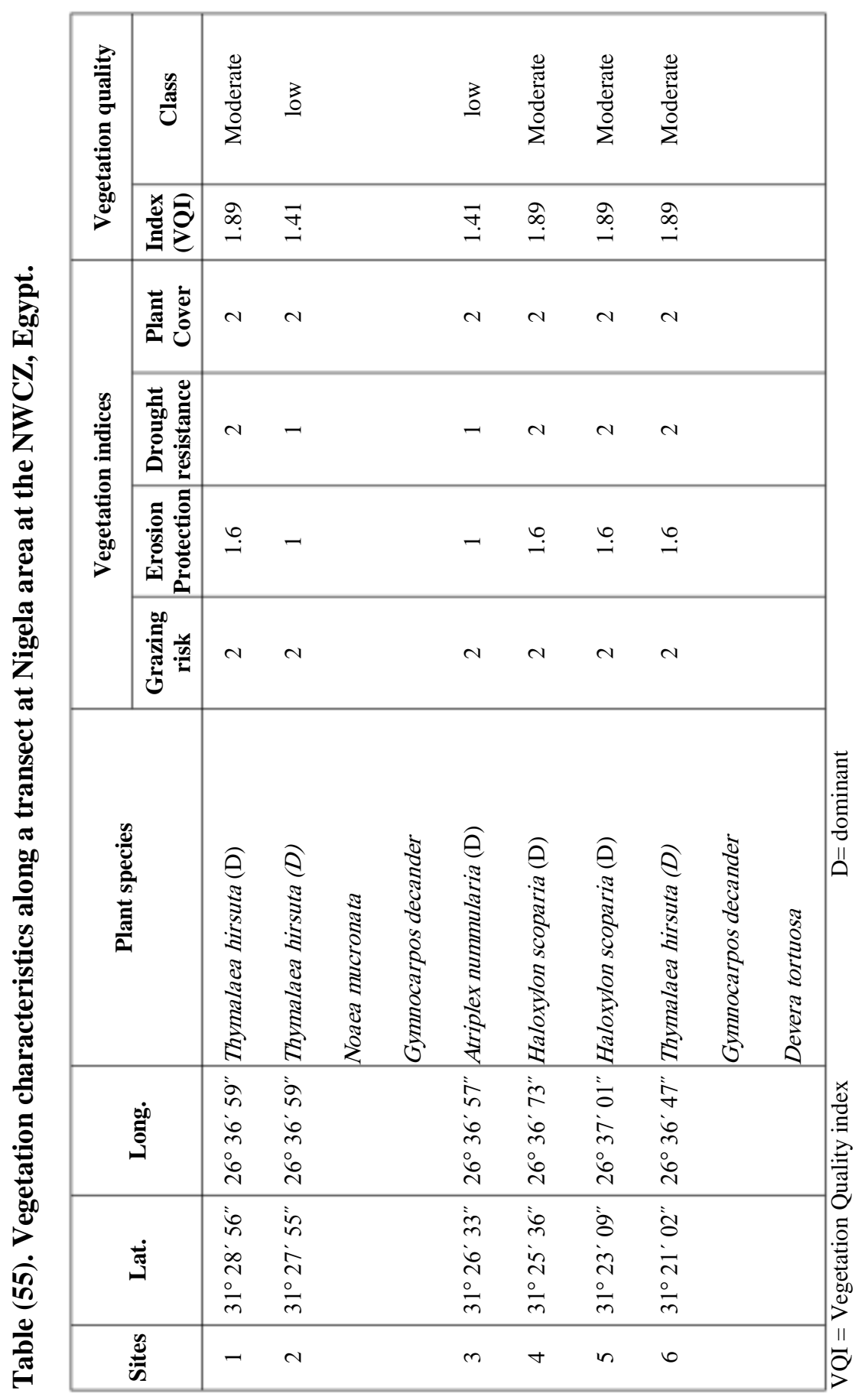

Egyptian J. Desert Res., 59, 1-96 (2009) 


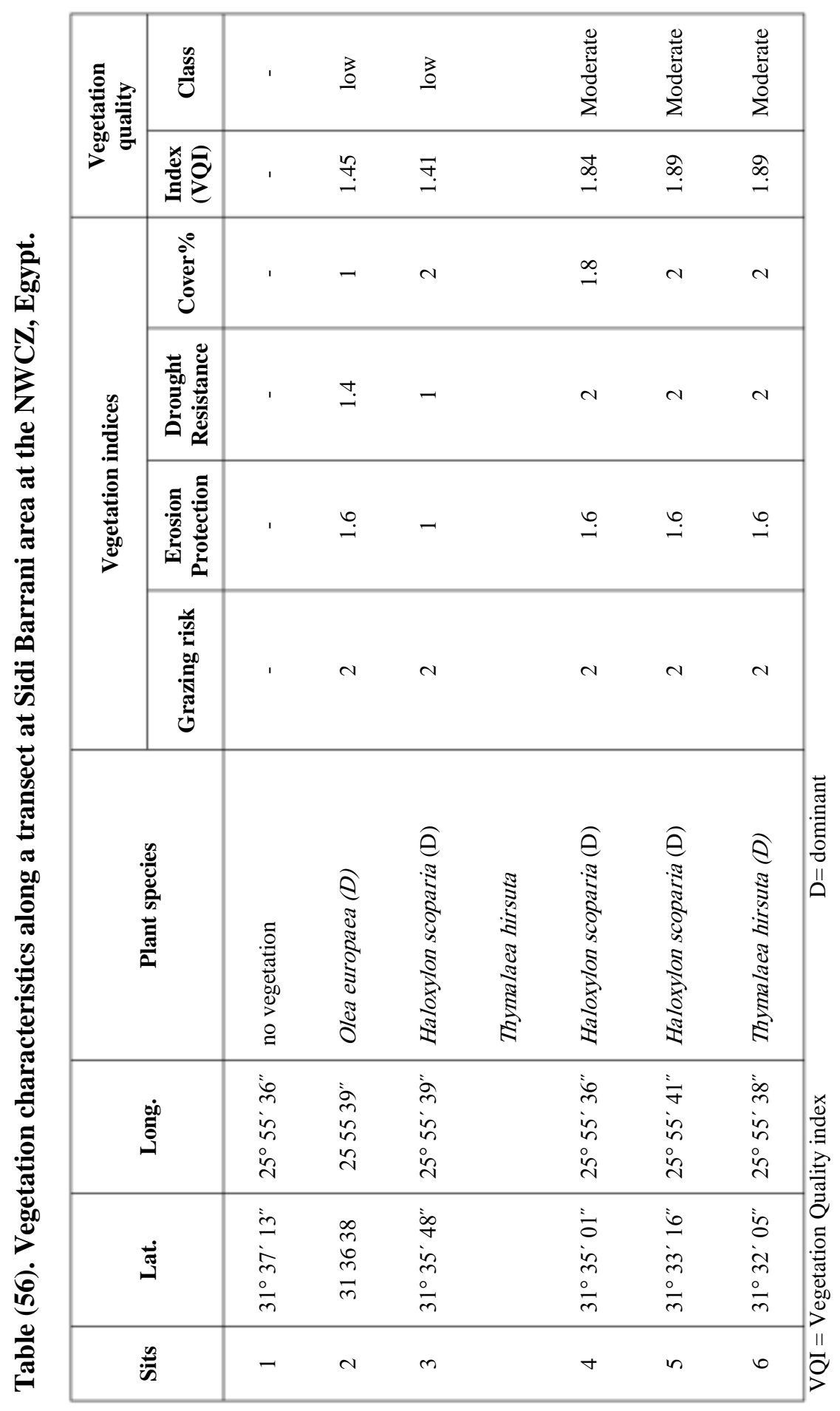

Egyptian J. Desert Res., 59, 1-96 (2009) 


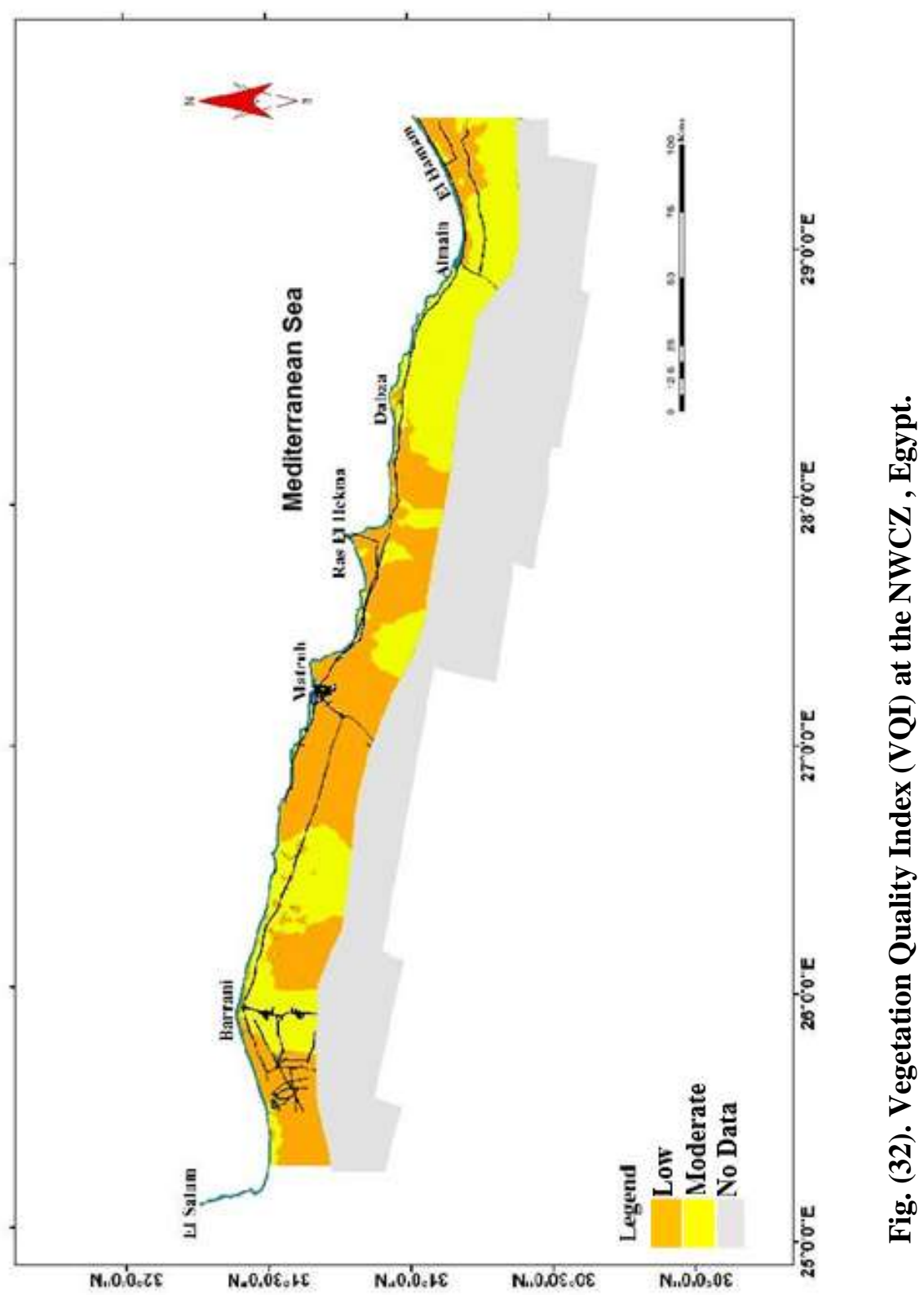

Egyptian J. Desert Res., 59, 1-96 (2009) 


\subsection{Management Quality}

In brief, the Vegetation quality index in the all studied transects was ranging from low to moderate (1.41-1.34) at Burg El-Arab, El-Dabaa and Ras EL-Hekma transects, where it was low (1.41-1.89) at the rest of transects.

Generally, the following comments can be recorded:

1- Decrease of plant cover and number of species from Burg El-Arab in the east to Sidi Barrani in the west. Decrease of plant cover from north to south in the vertical transects.

2- The wide spreaded species include Tamarix nilotica, Thymelaea hirsuta, Anabasis articulate, Atriplex halimus, Artemisia herba-alba, Retama raetam and Salsola tetrandra. All these species are either salt tolerant or drought resistant with poor plant cover and low productivity.

3- Overgrazing has negative effects on soil, decreasing its plant cover which protects it against erosion. Overgrazing brought about desertification and is the most effective factor in this regard.

4- Ploughing of soil and its preparation for cultivation increase sand movement and decrease land productivity, stimulate the appearance of salinization and decrease plant cover.

\subsection{Management Quality Index (MQI)}

Since early times, humans aimed to obtain their requirements to keep themselves survive, through the using of available natural land resources. Such land resources need a Rational utilization to prevent or minimize human-induced stress, which must be controlled by the following two actions:

a. Protection of the natural land resources from over use "sustainable uses".

b. Protection of the environment from hazardous actions and prevent the recesses affecting the development processes to reach, "sustainable development".

In other words, the sustainable uses of resources and development processes could be achieved with clean environment, where low degree of human-induced stress, i.e., management quality of land uses, and suitable policy for protection are practiced.

The principal classification of land use types is based on the criterion of the main purpose for which land is used. Based on this criterion, land use types, can be distinguished as follows:

a. Agricultural land (cropland, pasture or rangeland),

b. Natural areas (forests, shrubland, bareland),

c. Mining areas (quarries, mines, etc.),

d. Industrial areas, recreation areas (parks, compact tourism development, tourist areas, etc.),

e. Infrastructure facilities (roads, dams, etc.). 
The prevailing conditions of the NWCZ, dictated human to live in families and groups keeping their traditions and habits, therefore, most human activities of land-use take place in the form of agriculture land-uses. The cropland and pastureland for animal production are the main land-uses .Thus; these land-uses represent a source of income in such area. In details, these land-uses can be presented in the following:

\section{a- Cropland use}

Cropland use * Pastureland use

The area of study is characterized by special cropping pattern that is illustrated in table (57) with their cultivated areas (MEDRATE, 2001).

In this concern, one characteristic crop rotation system is applied in such area depending on rain-fed agriculture. This can be attributed to the fact of the rainfall timing, quantity and distribution, which are the main factors governing the agricultural activities. This common crop rotation system is:

fallow, barley and/or pasture and fallow, wheat and/or pasture.

Table (57). Cropping pattern at the NWCZ, Egypt.

\begin{tabular}{|l|c|}
\hline \multicolumn{1}{|c|}{ Crop } & Cultivated area/ 1000 fed. \\
\hline$\bullet$ Field crops & $90-135$ \\
- Barley & $40-50$ \\
- Wheat & 13 \\
\hline$\bullet$ Horticulture & 2 \\
- Fig & 5 \\
- Almond, Vine, and Pistachio & \\
-Olive & 42 \\
\hline$\bullet$ Vegetable & \\
-Onion, tomato and watermelon & \\
\hline
\end{tabular}

In this agriculture system barley occupies most of the cultivated area, followed by wheat, vegetables and fruit trees. This pattern of agricultural system could be changed according to climatic conditions. For example, the ratio of pastureland increased when rainfall was delayed during the winter season.

Moreover, in such agricultural system the uses of fertilizers and pesticides are at minimum, whereas ploughed machinery takes a more use situation.

\section{b. Pasture land use}

Natural rangeland nearly occupies about $90 \%$ of the total study area (MEDRATE, 2001), it is partially considered as feed resources of animal husbandry. In addition, the quantities of both cultivated barley and/or wheat, which can't complete their life circle, are used as additional resources.

The traditional animal production system depends on the natural rangeland, which is rapidly deteriorating. The scarcity of natural grazing, mainly in summer season, is the major problem facing the development of 
animal production. Under such condition, two types of production systems could be applied, as follow:

I. Extension production system, i.e., mobile system, based on indigenous rangeland which fluctuates greatly under the prevailed environmental conditions.

II. Semi-intensive production system, i.e., sedentary system, which is based, partially, on rangeland and cultivation of barley and fodder crops.

During the last few decades, the natural grazing lands have been exposed to degradation by several environmental factors. In addition, increasing the animal numbers/land unit or (carrying capacity) reaches a range of 10 to 40 head/feddan. This carrying capacity is actually amplified and encourage over grazing, thus, degradation of grazing areas takes place rapidly.

According to the method used for quantitative evaluation of the environmentally sensitive area`s (ESAs) to desertification (Kosmas et al., 1999), an algorithm for estimating the environmentally sensitive area index (ESAI) is worked out. Such algorithm includes the management quality index (MQI) as one of the other criteria quality indices. This quality index is evaluated as the geometric mean of land use intensity and the policy for enforcement environmental protection using the following algorithm:

$$
\text { MQI }=(\text { land use intensity Index } * \text { policy enforcement Index })^{1 / 2}
$$

With regard to the evaluation of management quality index (MQI) for the NWCZ, management characteristics of the major human activity is only the agricultural land use type, i.e., cropland and pastureland uses. Then, the previously algorithm will take the following form:

MQI $=(\text { cropland use Index } * \text { pastureland use Index } * \text { policy enforcement Index })^{1 / 3}$

As previously mentioned, (MQI) evaluation at the NWCZ will take place through the intensity of cropland and pastureland uses, as well as the policy enforcement, which will be discussed below.

\subsubsection{Land use intensity}

The data of agricultural land use, i.e., cropland and pastureland uses, are available among the Desert Research Center (DRC) studies, (DRC, 2001). The intensity of agricultural land use is conducted through the intensity evaluation of both cropland and pastureland uses separately, as follows;

\section{i) Cropland use intensity}

The intensity of land use for cropland is assessed by characterizing the degree of mechanization, existing terraces, the crop varieties used, the frequency of irrigation, the uses of agrochemicals, fertilizers, pesticides, etc. 
Three standard levels of cropland use intensity are distinguished as illustrated in table (58).

Table (58). Standard classes and weighting index values for the cropland use.

\begin{tabular}{|c|c|c|}
\hline Class & Description & Index \\
\hline 1 & Low Land Use Intensity & 1.0 \\
\hline 2 & Moderate Land Use Intensity (MLUI) & 1.5 \\
\hline 3 & High Land Use Intensity & 2.0 \\
\hline
\end{tabular}

According to the data of the cropland use in the NWCZ, it is evident that local plant varieties are used and the yields depend essentially on soil fertility and environmental conditions (no fertilizers, pesticides, or agrochemicals are added to the soil). Mechanization is limited only to seasonal crops, as one crop is cultivated after which the land remains fallow. Therefore, this cropland use is considered as extensive agriculture and the management quality belongs to low land use intensity (LLUI) class and its index value is 1.0 .

\section{ii) Pastureland use intensity}

With regard to the pastureland use, the available data dictate that the total area of natural pastureland is 457,443 fed., which used as grazing area. In this context, the numbers of grazing animals are 467,255 head of sheep, and 179,761 head of goats, then, the total number of grazing animals is, 647,016 head. The quality of management of pastureland can be evaluated through estimating the actual stock rate(ASR) carrying capacity, and comparing it with the sustainable stock rate(SSR), which can be calculated from the following equation;

$$
\mathrm{SSR}=\mathrm{X} * \mathrm{P} * \mathrm{~F} / \mathrm{R}
$$

Where:

SSR is the sustainable stock rate expressed as animals/fed.,

$\mathrm{R}$ is the annual biomass intake per animal sheep or goat 200.5 $\mathrm{Kg}$ /animal * year (as mentioned in the methodology text),

$\mathrm{X}$ is the fraction including grazing efficiency and correction for biomass not produced during the latest growing season,

$\mathrm{P}$ is the average palatable biomass after dry season $\mathrm{kg} / \mathrm{fed}$. and,

$\mathrm{F}$ is the average fraction of the soil surface covered with annuals plant species.

The values of actual stock rate (ASR) and sustainable stock rate (SSR) are calculated from the available data of DRC from which the obtained results are illustrated in tables (59) and (60). 
Table (59). The calculated actual stock rate (ASR) value for grazing animals at the NWCZ, Egypt.

\begin{tabular}{|c|c|c|c|c|}
\hline \multicolumn{2}{|c|}{$\begin{array}{c}\text { Number of grazing animals } \\
\text { (Head) }\end{array}$} & \multirow{2}{*}{$\begin{array}{l}\text { Total number of grazing } \\
\text { animals (Head) }\end{array}$} & \multirow{2}{*}{$\begin{array}{c}\text { Total area for } \\
\text { grazing } \\
\text { (Feddan) }\end{array}$} & \multirow{2}{*}{$\begin{array}{l}\text { Actual Stock } \\
\text { rate (ASR) }\end{array}$} \\
\hline Sheep & Goats & & & \\
\hline 467,255 & 179,761 & 647,016 & 457,443 & 1.4 \\
\hline
\end{tabular}

Table (60). The calculated sustainable stock rate (SSR) of grazing animals at the NWCZ, Egypt.

\begin{tabular}{|c|c|c|c|c|c|c|c|c|}
\hline \multicolumn{2}{|c|}{$\begin{array}{l}\text { Available grazing } \\
\text { areas (feddan) }\end{array}$} & \multicolumn{2}{|c|}{$\begin{array}{c}\text { Average } \\
\text { productivity of } \\
\text { palatable dry } \\
\text { materials (Kg) }\end{array}$} & \multirow{2}{*}{$\begin{array}{c}\text { Weighted } \\
\text { average of } \\
\text { productivity } \\
\text { per feddan } \\
\text { (Kg) }\end{array}$} & \multicolumn{2}{|c|}{$\begin{array}{c}\text { Reacquired } \\
\text { biomass intake } \\
\text { per animal (Kg) }\end{array}$} & \multirow{2}{*}{$\begin{array}{c}\text { Average } \\
\text { requirement } \\
\text { biomass intake } \\
\text { per animal } \\
(\mathrm{Kg})\end{array}$} & \multirow{2}{*}{$\begin{array}{c}\text { Sustainable } \\
\text { stock rate of } \\
\text { animal } \\
\text { (per feddan) } \\
\text { (SSR) }\end{array}$} \\
\hline $\begin{array}{c}\text { High } \\
\text { intensity }\end{array}$ & $\begin{array}{c}\text { Low } \\
\text { intensity }\end{array}$ & High & Low & & Sheep & Goats & & \\
\hline 192,609 & 647,016 & 78.4 & 315.4 & 216.5 & 216 & 185 & 200.5 & 0.3 \\
\hline
\end{tabular}

The obtained results indicate that the actual stock rate (ASR) is more than $1.5 *$ SSR of the pastureland use in the studied area. Therefore, the pastureland use of such area belongs to the third class (3) with an index value of 2.0 as illustrated in table (61).

Table (61). Standard classes and weighting index values for the pastureland use.

\begin{tabular}{|c|c|c|c|}
\hline Class & Description & Range & Index \\
\hline 1 & Low & ASR $<$ SSR & 1.0 \\
\hline 2 & Moderate & ASR $=$ SSR to $1.5 *$ SSR & 1.5 \\
\hline 3 & High & ASR $>1.5 *$ SSR & 2.0 \\
\hline
\end{tabular}

\subsubsection{Policy enforcement}

This concept means, the policies are enforced under the responsibility of the government through ministries related to the environmental land use protection. For example, policies favoring extensive agriculture, policies supporting terracing, and coastal protection policies, etc. These policies are evaluated according to the degree of implementation related to those of enforcement for each type of land uses, according to the used method. Then, the calculated values have been compared with those of the standard classes illustrated, in table (62). 
Table (62). Standard classes and weighting index values of the policy enforcement.

\begin{tabular}{|c|c|c|c|}
\hline Class & Description & Degree of enforcement & Index \\
\hline 1 & High & Complete: $>75 \%$ & 1.0 \\
\hline 2 & Moderate & Partial: $25-75 \%$ & 1.5 \\
\hline 3 & Low & Incomplete: $<25 \%$ & 2.0 \\
\hline
\end{tabular}

With regard to the NWCZ, the information on the policies concerning the prevailing land use are collected from different locality of agriculture departments, responsible for land use in such area and the Egyptian Environmental Affairs Agency. Then, the ratio of implementation/enforcement has been calculated and the obtained result equal to $18 \%$. The degree of enforcement pointed to this ratio is less than $25 \%$, belonging to class 3 , i.e., incomplete, with an index value of 2.0 as illustrated in table (62).

\subsubsection{Calculation of. Management Quality Index (MQI)}

Further elucidation of data is furnished by the (MQI) calculation for the NWCZ area. The final step comprises the matching of the results, previously obtained, for indices values of agriculture land uses, i.e., cropland and pastureland as well as policy enforcement using the following algorithm:

Management quality index $(\mathrm{MQI})=(\text { cropland } * \text { pastureland } * \text { policy })^{1 / 3}$

The final result of the management quality index (MQI) calculated value is 1.58 , thus it belongs to the management quality class 3 , as illustrated in table (63). Therefore, the management quality (MQ), i.e., human-induced stress of the studied area (NWCZ) is "low"

Table (63). Standard classes and weighted index values for the Management quality.

\begin{tabular}{|c|c|c|}
\hline Class & Description & Index \\
\hline 1 & High & $1.0-1.25$ \\
\hline 2 & Moderate & $1.26-1.50$ \\
\hline 3 & Low & $>1.5$ \\
\hline
\end{tabular}

The obtained results of the management quality index (MQI) value and class, means that the study area has a low quality of management. 
Furthermore, this low (MQI) value and class could be attributed to the improper utilization of pastureland and lowest score of the implementation when compared with the enforcement policies. In addition, pastureland must be utilized according to the scientific method of sustainable stock rate equation and maximizing the implementation of policy enforcement. The previous recommendation will protect the environment of the (NWCZ) from desertification and also, allows the sustainable development processes to take place.

\section{Environmentally Sensitivity Areas Index (ESAI)}

The final step to evaluate (ESAs) to desertification in the NWCZ comprises the matching of physical environment qualities and management quality as follows:

$$
\mathrm{ESAI}=(\mathrm{CQI} * \mathrm{RQI} * \mathrm{GQI} * \mathrm{SQI} * \mathrm{EQI} * \mathrm{VQI} * \mathrm{MQI})^{1 / 7}
$$

The range of (ESAI) for each type of the ESAs includes three subclasses in each type, (Table 64).

Table (64). Types of ESAs and corresponding ranges of indices.

\begin{tabular}{|c|c|c|}
\hline Type & Subtype & Range of ESAI \\
\hline Critical & $\mathrm{C}_{3}$ & $>1.53$ \\
\hline Critical & $\mathrm{C}_{2}$ & $1.42-1.53$ \\
\hline Critical & $\mathrm{C}_{1}$ & $1.38-1.41$ \\
\hline Fragile & $\mathrm{F}_{3}$ & $1.33-1.37$ \\
\hline Fragil & $\mathrm{F}_{2}$ & $1.27-1.33$ \\
\hline Fragile & $\mathrm{F}_{1}$ & $1.23-1.26$ \\
\hline Potential & $\mathrm{P}$ & $1.17-1.22$ \\
\hline Non affected & $\mathrm{N}$ & $<1.17$ \\
\hline
\end{tabular}

The ESAI was calculated for the NWCZ and the data which illustrated in table (65) and figure (33) show that, the values of sensitivity index to desertification are ranging from 1.39 to 1.5 , so the sensitivity of the area to desertification is in the range of critical type of first and second degree, it means that the studied area at the present time suffers from deterioration as a result of misuse and mismanagement of the natural resources, besides the severity of the climatic condition. Therefore, special attention must be taken 
into consideration to enhance the environmental equilibrium and put a rational and relevant plan to any new development in this zone.

Table (65). Calculated ESAI at the NWCZ, Egypt.

\begin{tabular}{|c|c|c|c|c|c|c|c|c|c|}
\hline Area & CQI & RQI & GQI & SQI & EQI & VQI & MQI & \multicolumn{2}{|c|}{ ESAs } \\
\hline $\begin{array}{c}\text { Burg El Arab - El } \\
\text { Dabaa }\end{array}$ & 0.852 & - & - & 1.74 & 1.7 & 1.45 & 1.58 & 1.42 & C2 \\
\hline $\begin{array}{c}\text { El Dabaa - Um El } \\
\text { Rakhm }\end{array}$ & 1.088 & 1.75 & 1.22 & 1.42 & 1.25 & 1.52 & 1.58 & 1.39 & $\mathrm{C} 1$ \\
\hline $\begin{array}{c}\text { Um El Rakhm - } \\
\text { Sidi Barrani }\end{array}$ & 0.919 & 1.66 & 1.22 & 1.56 & 1.7 & 1.77 & 1.58 & 1.45 & $\mathrm{C} 2$ \\
\hline $\begin{array}{c}\text { Sidi Barrani - El- } \\
\text { Sallum }\end{array}$ & 0.973 & 1.48 & 1.79 & 1.49 & 1.7 & 1.69 & 1.58 & 1.5 & $\mathrm{C} 2$ \\
\hline
\end{tabular}

\section{5- CONCLUSION AND RECOMMENDATIONS}

\subsection{CONCLUSION}

The present work aims at assessment and mapping the environmental sensitivity areas for desertification of the main agro-ecological Zones in Egypt. According to the National Action program these Zones are;

i) The Northern coastal zone; including the coastal area stretching eastward from the Northwestern coast to the Northern coastal area of Sinai

ii) The Nile Valley and Delta; encompassing, Nile Delta, Middle and upper Egypt and the reclaimed desert areas in the Nile Valley fringes

iii) The Inland Sinai and Eastern Desert

iv) The Western desert.

The Desert Research Center (DRC), as the focal point of the UNCCD in Egypt, has planned to accomplish this program due to its special importance to the policy makers and Land use planners to identify policies and measures that reverse the degradative trends and /or alleviate hazard and attain the sustainable development of the area.

The executed studies were based upon integrated indices to point out the potential risk of desertification using the mathematical model by Kosmas 
(1999). The first phase of these studies was devoted to the North Western Coastal zone in which, the obtained results revealed the following:

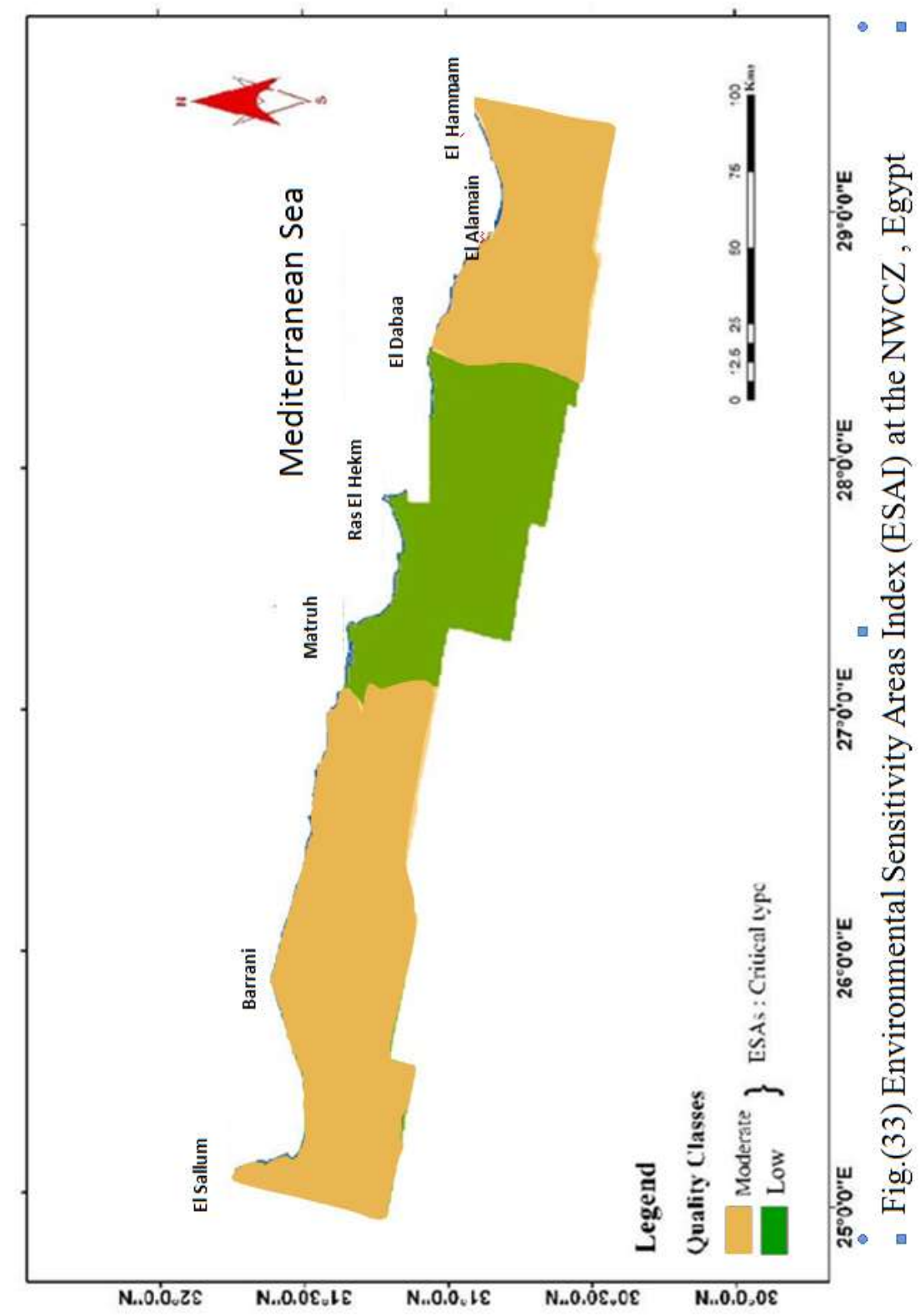

Egyptian J. Desert Res., 59, 1-96 (2009) 
1- The study area represents the coastal strip of the North Western Coastal Zone (NWCZ) which extends from Alexandria on the East to El-Sallum on the far West for about $500 \mathrm{~km}$ with an inland depth of $20 \mathrm{~km}$ South. Therefore, it occupies an area of about 10,000 km (2.4 million feddan). Geographically, the area is located between latitudes $30^{\circ} 30^{\prime}$ and $31^{\circ} 40^{\prime} \mathrm{N}$ and longitudes $25^{\circ} 10^{\prime}$ and $29^{\circ} 50^{\prime} \mathrm{E}$,

2- Geomorphologically, the study area is divided into the following:

- The Coastal Plain

- The Piedmont Slopes

- The Tableland

- Hydrographic Basins

3- Geologically, the study area is essentially dominated by sedimentary rocks of Tertiary and Quaternary ages. The Quaternary deposits are exposed in the coastal plain, wadis and beaches. The Tertiary Pliocene deposits are exposed in the study area, while the Tertiary Miocene forms the surface beds of the plateau.

4- Climatologically, the climate of the North Western Coastal Zone is characterized by long rainless summer and short rainy winter, from October to April, with limited variation in daily temperature. In general, the zone is related to the Arid or Hyper arid Mediterranean climate.

5- Hydrologically, In general, groundwater aquifers could be distinguished into:

* Quaternary aquifer (Pleistocene),

* Fractured limestone aquifer (mid Miocene)

Evaluation of 131 wells dissecting the Quaternary and mid Miocene aquifers were carried out. The groundwater level in the region is either above sea level ( $80 \%$ of wells) or below sea level ( $20 \%$ of wells). The groundwater salinity in these aquifers is usually saline when water level is below sea level while above sea level water salinity is most probably brackish to fresh.

Rainfall storm of an amount of $10 \mathrm{~mm}$, the corresponding specific surface runoff (overland flow) will be equal to about $270 \mathrm{~m}^{3} / \mathrm{km}^{2}$. However, the rainfall storm of $20 \mathrm{~mm}$ will result a specific surface runoff (overland flow) of about $3150 \mathrm{~m}^{3} / \mathrm{km}^{2}$.

The studies also indicate that groundwater of Ras El-Hekma and Sidi Shebib village at $\mathrm{km} 112$ east Matruh and south the paved road, have water salinity of about 700ppm, therefore studies are extended to clarify the source of recharge and the extent of distribution of such condition.

6- Data on the monthly rainfall and calculation of the average annual rainfall for different localities along the coast reveal that all values reach their maximum at Om El-Rakham while being at minimum in Burg El-Arab. It is observed that such values increase closer to the sea shore and decrease towards south. Data also show that erosion 
causative factor is rainfall storms where intensity is more than 10 $\mathrm{mm}$ that takes place 2-6 times/year. It is also evident that the relative increase of surface water velocity hazards is mainly concentrated in west Matruh and El- Dabaa areas. Thereforee, it is essential to apply soil and water conservation practices to protect those areas from water erosion hazards

7- In general, the NWCZ is also susceptible to wind erosion due to prevailing climatic conditions and detailed study is needed on basis of more precise climatic information and delineation of locations susceptible to wind erosion, then proper mapping of wind erosion hazards along NWCZ. Also, a thorough evaluation of wind velocity and direction over the whole year is essentially needed to design wind breaks in linear or curvilinear lines with proper distance between trees especially west Matruh (Sidi Barrani) and south ElKasr locations.

8- The plant cover in the NWCZ can be discriminated into seven types:

*Fruit trees (Cultivated olive, figs, grape, ..... etc.)

*Crops (mainly barley \& wheat).

*Densely covered rangelands.

*Moderately covered rangelands.

*Lightly covered rangelands.

*Sandy and rocky plants.

* Salt marshes plants.

9- Soils were classified as follows:

*Typic Calcids

* Lithic Calcids

* Gypsic Aquisalids

* Lithic Torriorthents

*Lithic Torripsamments

* Oolitic Calcipsamments

9- An evaluation of desertification sensitivity for the NWCZ environment was carried out through the measurement of specific indicators namely; climate quality index (CQI), run off quality index $(\mathrm{RQI})$, ground water quality index (GQI), soil quality index (SQI), erosion quality index (EQI), vegetation quality index(VQI) and management quality index (MQI) which are calculated according to a mathematical model for each indicator then compiled in a final mathematical model to demonstrate environmental sensitivity for desertification (ESAs). An account on the evaluation of the foregoing indicators is given as follows:

i) CQI was used to detect the effect of climate through its effective elements; rainfall, wind speed and direction and, aridity index. one equation was employed to calculate aridity index in the NWCZ and the obtained results indicate a low quality climate. 


$$
\mathrm{CQI}=\left((\mathrm{Ir})^{*}(\mathrm{Ia})^{*}(\mathrm{Is})^{*}(\mathrm{Im})\right)^{1 / 4}
$$

The obtained figure (0.628) of the CQI belongs to class (3) that means the climatic quality in the NWCZ has low quality.

ii) RQI was determined using the factors that affect the susceptibility of the environment to desertification including daily rainfall which causes surface runoff and consequently rain risk, frequency of rainstorms and slope and gradient of water basins.

$$
\mathrm{RQI}=(\mathrm{Ire})^{*}(\mathrm{Ifr})^{*}(\mathrm{Igr})^{1 / 3}
$$

The results revealed that is moderate from Matruh to EL-Sallum and it is low form Dabaa to Matruh.

iii) GQI was determined using the following equation:

$$
\text { GQI }=(\text { Water Salinity Index } * \text { Water Depth Index })^{1 / 2}
$$

Two factors were considered for GQ1, firstly salinity of groundwater, secondly water depth. The obtained results reveal that GQI is moderate from Dabaa to Barrani, while it is low from Barrani to El-Sallum.

iv) SQI was determined using the following equation:

$$
\mathrm{SQI}=\left(\mathrm{Ip} * \mathrm{Id}^{*} \mathrm{It}^{*} \mathrm{Isg}^{*} \mathrm{Ir}^{*} \mathrm{Isd}^{*} \mathrm{Isa}\right)^{1 / 7}
$$

This quality can be evaluated by using simple soil properties such as: parent material, soil depth, soil texture, slope gradient, rock fragments cover, soil drainage and soil salinity. The obtained results revealed that the area that has moderate SQI (1.13-1.45) cover about $66.65 \%$ of the study area. Meanwhile, the low SQI (> 1.45) covers about $32.66 \%$,

v) EQI was determined using the following equation:

$$
\mathrm{EQI}=(\mathrm{WEHI}) \mathrm{X}\left(\mathrm{W}_{\mathrm{i}} \mathrm{EHI}\right)^{1 / 2}
$$

The values of soil loss by water and wind erosion were used for assessing the erosion quality index (EQI). Erosion quality index of the NWCZ was estimated and the results revealed that it is moderate along the NWCZ except the area from Dabaa to UM El Rakhm where the EQI is high.

vi) VQ1 was determined using the following equation:

$\mathrm{VQI}=(\text { vegetation cover } * \text { Drought resistance * Erosion protection * Grazing risk })^{1 / 4}$

VQI is estimated through indicators of drought- resistant vegetation, control of erosion, overgrazing and vegetation cover either cultivated or natural. The obtained results dictate that the vegetation cover and number of plant species depressed horizontally from Burg El-Arab towards El-Sallum and also from north to south, those patterns are proportional to rainfall along NWCZ. It is also evident that drought and salt tolerant vegetations are common. In brief, the Vegetation quality index in the all studied transects was ranging from low to moderate (1.41-1.34) at Burg El-Arab,El-Dabaa and Ras EL-Hekma transects, where it was low (1.41-1.89) at the rest of transects.

vii) $M Q I$ was determined using the following equation: 


$$
\mathrm{MQI}=(\text { land use intensity } * \text { policy enforcement })^{1 / 2}
$$

This index is estimated through land use intensity of crops and grazing as well as evaluating of implementation policy. According to the computed management quality of NWCZ, it is clear that the management quality is low $(>1.51)$ in regard to environmental conservation plan, overgrazing scheme since number of different grazing animals is not proportional to available grazing area beside the non-conventional plan and practices for land reclamation, improvement and conservation for sustainable agriculture and grazing as well as the inadequate practices to control wind erosion and runoff hazards.

Viii) ESAI was determined using the following equation:

$$
\mathrm{ESAI}=(\mathrm{CQI} * \mathrm{RQI} * \mathrm{GQI} * \mathrm{SQI} * \mathrm{EQI} * \mathrm{VQI} * \mathrm{MQI})^{1 / 7}
$$

ESAI values were computed on basis of the seven aforementioned indices to evaluate the sensitivity of NWCZ to desertification. The obtained results reveal that the ESAs at the present time is considered of degradation critical type of first and second degree. This endangered situation is rendered to the non-conventional use of natural resources and their random management. Moreover, the inappropriate plans to control physical phenomena that lead to wind and water erosion. To alleviate the environmental imbalance and maintain sustainable development for the NWCZ, the following recommendations should be followed.

\subsection{RECOMMENDATIONS}

- Priority should be given to land reclamation, cultivation and development of intervening depressions and wadis ended by alluvial fans which occupy pronounced area of about 785,500 feddan, i.e. about $32.73 \%$ of the total area of NWCZ.

- Lands development in the NWCZ is preferred inlands of low sensitivity to desertification relative to the portion which has moderat sensitivity.

- Updating and completion of data and detailed soil properties of gaped area and recoding and correction of limitations opposing productivity in the NWCZ especially the coarse-textured soils in Dabba area.

- Expanding the use of the structural plateau soils in the shallowrooted. This plateau can preferably be used for rainfed agriculture of grain crops with ground water supplemental irrigation together with barley cultivation in the depressions. Besides, other soils particularly those of the northern portion of NWCZ should be cultivated with fruit orchards and field crops depending on soil properties and their suitability to grown crops. 
- Stimulating and support water harvesting of rain and runoff water using earthen dams, $300 \mathrm{~m}^{3}$ capacity for runoff and cement reservoirs of $2000 \mathrm{~m}^{3}$ capacity to capture rain water directly.

Encouraging the establishment of stone dikes and stop constructing cement dikes eventually since the latter prevent water movement downwards thus increases desertification.

Constructing L-shaped stone dikes that do not interrupt wadi width completely and facilitate free water movement downwards the wadis. These dikes help in thorough water distribution and soil moisture along the wadis either in upper or lower portions as well as charging ground water.

Dikes should be opposing and not for water storage, this can be achieved by stone dikes rather than the costly cement dikes.

- Runoff water should not be directed to the sea or to the coastal depressions covered by sabkhas but to coastal depressions and attain groundwater potentiality that can be employed through hand- dug wells or caves.

- Fully implement the wadis of the plateau and El-Sallum bay for sustainable development of natural resources (water, soils and rangeland) since the ranglands need propagation, diversity, management and proper orientation to develop animal husbandry on a national level and considered as protected environmental areas.

- Monitoring and controlling of wind erosion caused by the spring southerly winds that have a destructive effect on the thin superficial soils impoverished in plants cover, thus increased erosion intensity.

- Groundwater exploration should be counteracted in area discharging very saline water (>10,000 ppm) especially in Garawla, kasr and Sidi Barrani localities.

- Encourging wells drilling in areas having low salinity- water like Ras El-Hekma, El Dabaa and numerous wadis along the coast west Matruh, to be used for supplemental irrigation. In this regard, the ground water potentiality in many wadis is promising, has low salinity, seasonally generated and aquifer thickness is adequate.

- Appropriate use of ground water in sustainable development, bearing in mind that drilling and water discharge rate should be proportional to the potentiality of the aquifers and eliminate sea water intrusion due to extensive pumping.

- Carrying out a survey and classification of natural vegetation cover and cultivated crops along the NWCZ and prepare a vegetation map as a baseline for continuous monitoring of desertification.

- Specify trees, bushes, crops and natural vegetations that are droughtresistant and play sound role in controlling wind and water erosion. 
- Make more systematic and continuous evaluation of rangeland capacity to control overgrazing and combat desertification.

- Optimize agricultural management practices; irrigation, fertilization, manuring, mechanization and Pest control for all grown crops, vegetables and fruit orchards to improve the cropland use intensity for sustainable agricultural use.

- Integrating environmental concern in economic decisions.

- Streamline the legal environmental framework and facilitate its implementation through setting clear environmental policy targets and implementation deadline.

- Evaluate the cost-effectiveness of policy for land use planning, combating desertification and protection of the environment.

- Complete the geographical coverage of desertification sensitivity studies of the other agro-ecological zones.

- Promote further actions to sustain development of NWCZ.

\section{ACKNOWLEDGMENTS}

The editorial board and contributors are grateful to Prof. Dr. Mohamed Yehia Draz, X-president of the Desert Research Center for his full support and assistance during the ongoing and completion of this work. Also, special thanks to Prof. Dr. Asmaa Abdo Shata; the former Editorial Secretory of the journal, for her careful review of this manuscript.

\section{REFERENCES}

Ahmed, M.A. (1983). Local Studies on the Natural Resources in El kasr and Fuka localities, North Western Coastal Zone. Academy Sci. Res. and Tech., Egypt.

Chepil, W.S.; N.P. Woodruff; F.H. Siddoway; D.W. Fryrear and D.V. Armbrust (1963). Vegetative and nonvegetative materials to control wind and water erosion. Soil Science Society of America Proceedings, 27: 86-89.

CONOCO Inc. (1989). In "Stratigraphic Lexicon and Explanatory Notes to the Geological Map of Egypt 1:500,000". (Hermina, M., E. Klitzsch and F.K. List eds.). CONOCO Inc., Cairo, Egypt, 263 pp.

El Shazly, M.A. (1978). Morphological studies of some soils along the north western coast of Egypt. M.Sc. Thesis of Soil Sci., Al Azhar Univ., Cairo, Egypt.

FAO (1970). Pre-investment Survey on the Northwestern Coastal Zone, Physical Conditions and Water Resources. United Nations Development Programme.

Egyptian J. Desert Res., 59, 1-96 (2009) 
Fryberger, S.G. and G. Dean (1979). In "Dune Forms and Wind Regime". (Mckee, E.D. ed.). A Study of Global Sand Seas, U.S. Geological Survey Professional Paper, 1052:137-169.

Fryrear, D.W. (1986). Mechanics of erosion: measurement, prediction and control. Soil, water and crop /livestock management systems for rainfed agriculture in the Near East Region. Proceedings of the workshop at Amman, Jordon, p. 136-146.

Fryrear, D.W. (2000). In "Wind Erosion". (Sumner, M.E. et al. eds.). Handbook of Soil Science. CRC Press, London, UK.

Hammad, M.M. (1968). Genesis of the soils of Western Mediterranean Coast of UAR. Ph.D. Thesis of Soil Sci., Fac. of Agric., Ain Shams Univ., Egypt.

Heneidy, S. (2002). Browsing and nutritive value of the most common range species in Matruh area, a coastal Mediterranean region, Egypt. Ecologia Mediterranea, 28(2):39-49.

Khedr, A.A. (2006). Regional patterns of rarity and life history elements in the flora of Egypt. Tockholmia, 26:141-160.

Kosmas, C.; M. Kirkby and N. Geeson (1999). Key indicators and methodology for mapping environmentally sensitive areas (ESA's) to desertification. The MEDALUS Project, European Commission Project ENV4 CT 950119, 187 pp.

Lal, R. and W.E. Elliot (1994). In "Erodibility and Erosivity, Extreme Events and Research Methods". Soil and Water Conservation Society, Ankeny.

Lyles, L.; L. Hagen and E. Skidmore (1983). In "Soil Conservation: Principles of Erosion by Wind". Dryland Agriculture. Madison (WI): American Society of Agronomy, p. 177-188.

MEDRATE (2001). Evaluation of agricultural practices to improve efficiency and environment conservation in Mediterranean arid and semi-arid production system: CIHEAM- Desert Research Center Cooperation Project, $1^{\text {st }}$ Report.

Morgan, R.P.C. (1995). In "Soil Erosion and Conservation". $2^{\text {nd }}$ Ed. Longman, Harlow, U.K.

OSS (2004). Map of Sensitivity to Desertification in the Mediterranean Basin-Proposal for the Methodology for Final Map. Rome, Italy.

Pye, K. and H. Tsoar (1990). In "Aeolian Sand and Sand Dunes". Unwin Hyman, London.

Rose, C.W. (1998). In "Modeling Erosion by Water and Wind". (Lal R. et al. eds.), Methods for Assessment of Soil Degradation. CRC London, UK, p. 57-88.

Saleh, A. (2000). Hydrological, geomorphological and geoenvironmental implications for future sustainable development of the 
northwestern coastal zone of Egypt. Ph.D. Thesis, Fac. of Sci., Mansoura Univ., Mansoura, Egypt.

Salter, R. (1984). Wind Erosion. Speden I, Crozier MJ (compilers) Natural Hazards in New Zealand, New Zealand National Commission for Unesco, Wellington, p. 206-248.

Sen Roy, S. and R. Singh (2002). In "Climate Variability, Extreme Events and Agricultural Productivity in Mountain Regions". Oxford, IBH Publications, New Delhi.

Sharkawy, S.F.T. (2006). Climatic erosivity and soil erodibility as indicator for wind erosion rate in some areas of Egypt. Journal of Environmental Research (Zagazig Univ., Egypt), 7: 11-28.

Shrestha, D.P. (1997). Assessment of soil erosion in the Nepalese Himalaya: a case study in Likhu Khola Valley, Middle Mountain Region. Land Husbandry, 2(1): 59-80.

Thornthwaite, C.W. (1948). An approach toward a rational classification of climate. Geographical Review, p. 55-94.

UNEP (1992). In "World Atlas of Desertification". The United Nations Environment Programme (UNEP), London.

UNESCO (1995). In "Rainfall Water Management in the Arab Region". State of the Art Report, ROSTAS, Cairo.

USDA (1995). Water Erosion Prediction Project (WEPP), National Soil Erosion Research Laboratory, User Summary NSERL. Int. J. Report, No. 11, Vol. 11 July, 141 pp.

Wischmeier, W. and D. Smith (1978). In "Predicting Rainfall Erosion Losses: A Guide to Conservation Planning". U.S. Department of Agriculture Handbook, No. 537.

Woodruff, N. and F. Siddoway (1965). A wind erosion equation. Soil Science Society of America Journal, 29(5): 602-608.

Zaki, H.H. (2000). Assessment of surface water runoff in Mersa Matruh area, Northwestern Coastal Zone. M.Sc. Thesis, Faculty of Science, Alexandria Univ., Egypt. 


\section{تقييم وتخريط الحساسية للتصحر في إقليم الساحل الثمالي الغربي- مصر}

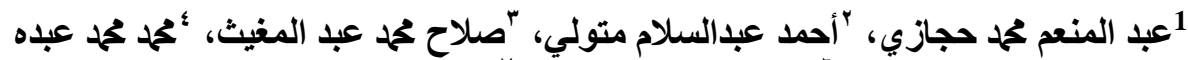

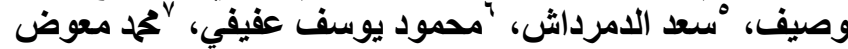

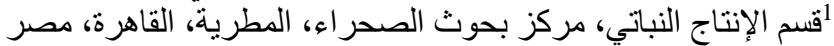

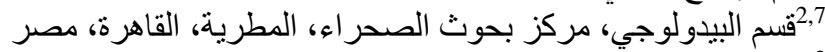

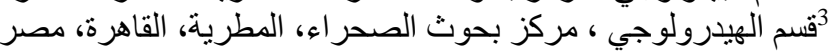

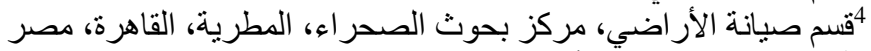

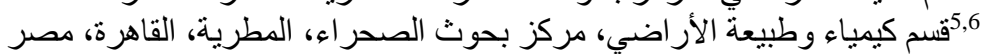

تهدف الدر اسة إلي تقييم وتخريط حساسية منطقة الساحل الثمالي الغربي للتصحر البيئي

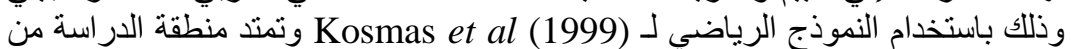

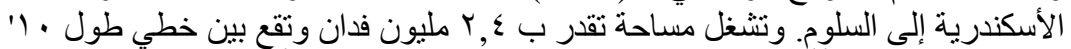

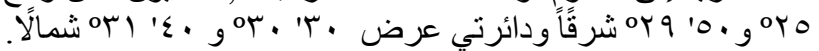

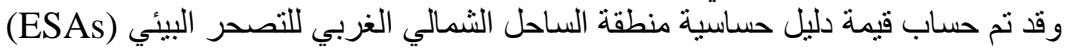

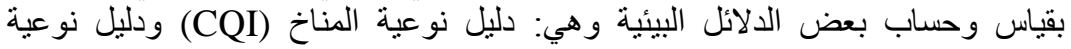

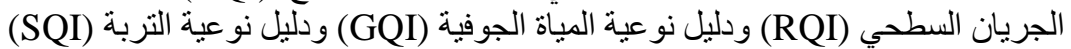
ودليل نوعية التجوية (EQI) ودليل نوعية الغطاء النباتي (VQI) ودلية (VQI) ودليل نوعية الإدارة (MQI)

$$
\text { • • دليل نوعية المناخ كان منخفضًا. }
$$

$$
\text { النحو التالي: }
$$

• دليل نوعية الجريان السطحي كان منخفضيًا غرب مطروح ومتوسطًا شرق

$$
\text { مطروح. }
$$

• دليل نوعية المياة الجوفية كان منوسطًا شرق بر اني ومنخفضًا غرب بر اني.

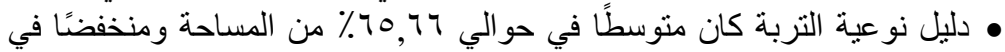

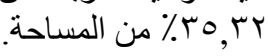

• دليل نو عية التجوية كان منخفضًا بطول التهان الساحل الثمالي الغربي، بينما كان مرتفعًا

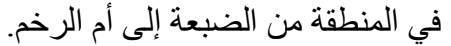

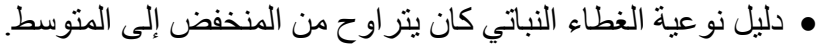

$$
\begin{aligned}
& \text { • • دليل نوعية الإدارة كان منخفضًا. }
\end{aligned}
$$

• دليل حساسية المنطقة للتصحر البيئي كان يقع تحت الحالة التهانة الحرجة من التدهور في

$$
\text { مرحلتيه الأولى و الثانية. }
$$

وقد أمكن التوصل إلى بعض التوصيات بهذه الدر اسة وهي أن نبدأ في التنمية في المناطق

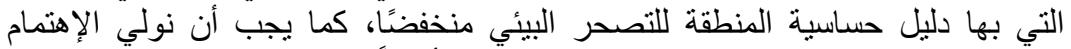

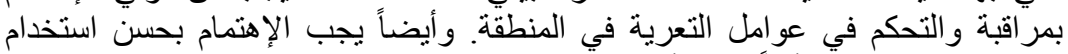

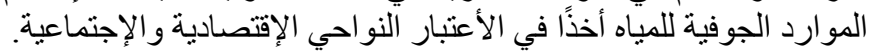


